\title{
Relationships between fauna and people and the role of ethnozoology in animal conservation
}

\author{
Rômulo Romeu Nóbrega Alves \\ Departamento de Biologia, Universidade Estadual da Paraíba, Av. Baraúnas \#351, Bodocongó, \\ Campina Grande, PB, 58430-335, Brasil \\ $\triangle$ E-mail: romulo_nobrega@yahoo.com.br
}

Ethnobiology and Conservation 2012, 1:2 (4 October 2012)

ISSN 2238-4782

doi: 10.15451/ec2012-8-1.2-1-69

ethnobioconservation.com

\begin{abstract}
Faunal resources have played a wide range of roles in human life from the earliest days of recorded history. In addition to their utilitarian importance, animals have been recognized in religion, art, music and literature and other different cultural manifestations of mankind. Animals uses and the means by which they are exploited by humans, as well as the cultural aspects which conduct interactions between people and animals, are implicated in a lower or higher pressure on populations of exploited species, reflected in either their sustainable use or even lead to their extinction. The variety of interactions between humans and animals is the subject matter of ethnozoology - the branch of ethnobiology that investigates the knowledge human societies have accumulated concerning animals, as well as their significance to those people and their uses. Ethnozoological studies can be a valuable asset to increase our understanding of the cultural, economic, social, and traditional roles of played by animals. In this context, they have a central role in conservation and management. This work provides a review on the main forms of interactions between humans and the fauna along history, and their ecological implications, and discusses the role of the ethnozoology in animal conservation.
\end{abstract}

Keywords: Biodiversity conservation - Ethnobiology - Wildlife use 


\section{Introduction}

Humans share the world with a bewildering variety of other animals, and have always made attempts to understand them (Allaby 2010). Human-animal interactions have constituted a fundamental connection in all societies throughout history (Kalof and Resl 2007; Marques 1995). Mute testimony to this ancient and ongoing fascination with animals lies deep within caves in Europe and the Middle East (Springer and Holley 2012). Ancient human-animal relationships can be seen in rock paintings depicting wild animals such as bison, horses and deer being hunted by human figures (Alves et al. 2010a). The oldest cave paintings showing humans interacting with animals are some 35,000 years old (Clottes 2003). Some scholars argue that, in addition to depicting the obvious functional relationships between hunter and prey, these paintings also represent the spiritual connections which have united humans and animals in the context of a hunter-gatherer mode of subsistence since the Palaeolithic (Hurn 2012). The animals are drawn in great detail, in stark contrast to the accompanying matchstick-style human hunters, and this difference is suggestive of the reverence with which humans once regarded the animals on whose lives and deaths their own survival depended (Hurn 2012).

Animals have always formed, and will always form, a central feature of the human world (Manning and Serpell 1994). Cultures across the world have over time developed characteristic ways of interacting with their regional fauna. Humans have always attempted to understand animals, to enslave them, and to capture their strength and power (Holley 2009). Faunal-derived products are used in many ways, especially as food, but also as clothing and tools, and for medicinal and magicreligious purposes (Alvard et al. 1997; Alves et al. 2007, 2009a; Alves and Rosa 2012; Fitter 1986; Inskip and Zimmermann 2009; Prins et al. 2000). Human relationships with animals go beyond simple utilitarian considerations, for there have been strong supernatural associations between their worlds (Alves and Souto 2010). Many cultures have mythologies, and many show close integration and connections with totemic, ancestral or mythological (imaginary) animals or animal-gods which are said to have been present throughout human history (Allaby 2010; Leo Neto et al. 2011, 2012).

The variety of interactions (both past and present) between human cultures and other animals is the subject matter of ethnozoology, a discipline that has its roots as deep within the past as humans themselves (Alves and Souto 2010; Alves and Souto 2011). In a broader context, ethnozoology and its companion discipline, ethnobotany, form part of the larger body of science of ethnobiology. According to Clément (1998), the history of ethnobiology can be divided into three periods: preclassical, classical and post-classical. This author noted that during the pre-classical period (which began in about 1860) studies were focused on collecting information about resource usage while, during the classical period (which began in 1954), a large number of linguistic studies and ethnobiological classifications (many of which had an emic perspective) were undertaken, increasingly using methodologies deriving from anthropology. We are currently in the post-classical period of ethnobiology that began in 1981, and which is marked by the appearance of academic societies and specialized journals and by the many researchers who are converging on the study of natural resources.

In recent years, the importance of ethnobiological studies for biodiversity conservation has increasingly been recognized (Alves et al. 2009a; Cunningham 2001; Drew 2005; Fernandes-Ferreira et al. 2012a; Tidemann and Gosler 2010), 
unsurprisingly given the strong human influence on biodiversity. Humans are integral components of ecosystems; likewise, the functions and products of ecosystems are critical to social systems (Chapin and Whiteman 1998). Anthropogenic activities are associated directly or indirectly with alterations to the Earth's biological diversity (Chapin III et al. 2000; Haberl et al. 2006). People, in turn, are sensitive to the supply of natural resources available for consumption (Bogart et al. 2009). These resources constitute the material foundation of cultural systems (Fischer-Kowalski and Weisz 1999). Humans also incorporate their experiences with nature into the symbolic realm of culture, for example through art, music, ritual, and the cultural significance imparted to human artefacts (Haberl et al. 2006; Jacobson and Duff 1998). Regional ecological and social systems are tightly associated and interdependent; major changes in either one will have repercussions in the other (Bogart et al. 2009).

In the specific case of fauna, their uses and the means by which they are exploited by humans, as well as the cultural rules which conduct interactions between people and animals, are implicated in a lower or higher pressure on populations of exploited species, reflected in either their sustainable use or even lead to their extinction (Alves et al. 2008, 2010b). In order therefore to secure a future for animal populations, conservationists must understand not only the ecological, but also the cultural and economic interactions that link ecological and social systems into a common regional system, and the feedbacks that govern these interactions (Alves and Albuquerque 2012a; Bogart et al. 2009; Chapin and Whiteman 1998; Geist and Lambin 2002). In this context it is inconceivable that animal conservation strategies can be created without considering humans and their interactions with other animals, highlighting the importance of ethnozoological studies. This work presents a review focusing on the main historical and current interactions between humans and the fauna, the ecological implications and the role of the ethnozoology in animal conservation.

\section{Interactions between people and animals}

The relationship between people and animals has existed since ancient times, and has been expressed in different ways, reflecting influences arising from both environmental conditions and culture. A single species can be used in different ways and for different ends by different societies, depending on its proposed use and associated cultural aspects. In general, animals interact with human communities because of their utility or because of the risks they represent. Moreover, many stories, myths and proverbs have been generated from these relationships and passed from generation to generation through oral tradition, influencing how local people relate to animals. Hereafter are briefly discussed the main means of interaction between humans and fauna, which have been the focus of ethnozoology. The potential role of this discipline for biodiversity conservation will be discussed later.

\section{Animals as food sources}

Clearly, one of the most fundamental uses of animals is to meet nutritional needs (Reitz and Wing 2008). Humans have used wildlife as food since prehistoric times (Leakey 1981; Morris and Morris 1965; Sponheimer and Dufour 2009). 
Archaeological researchers have determined that humans have consumed a wide variety of fish, molluscs, birds, mammals, reptiles and amphibians (Emery 2007; Foster and James 2002; Hamblin 1985; Jorgenson 1998; Kyselý 2008; Masson 1999; Masson and Peraza Lope 2008; McKillop 1984; McKillop 1985; Pohl 1976, 1981). Recently, Waters et al. (2011) noted that humans were engaged in hunting Mastodon at least as early as 13,800 years ago, thus providing evidence for the age of hunting practice. Further evidence of hunting by prehistoric people can be seen in rock paintings depicting wild animals such as bison, horses, and deer being hunted by human figures.

Meat and fish have been the primary source of protein for many human cultures throughout history (Gross 1975). The quest for these resources is reflected in the development of a series of techniques and strategies that characterize two of the oldest activities of mankind: fishing and hunting. Although not in possession of a typical carnivore morphology, human beings have succeeded in becoming the most efficient predator in the world (Ojasti and Dallmeier 2000), especially in more recent years with the evolution of modern hunting and fishing technologies.

While invertebrates can be locally important dietary items, it is the larger vertebrates that constitute the majority of the terrestrial wild animal biomass consumed by humans (Nasi et al. 2008). In general, of the main vertebrate groups targeted by hunting activities the most prominent are mammals, birds and reptiles (Klemens and Thorbjarnarson 1995; Redford and Robinson 1987; Robinson and Redford 1991). In fact, mammals comprise the preferred source of food because of their size and the possibility of yielding a greater return for the energy invested in hunting (Albuquerque et al. 2012). As might be expected, hunters focus initially on large animals, and continue to hunt them even when their numbers become low (Nasi et al. 2008). It should be highlighted that in areas where there is not an abundance of larger-sized mammals, other vertebrates may present a similar or greater hunting significance. In semi-arid regions of Brazil, for example, a recent study has revealed that avifauna is the most notable group of species consumed (when considering species richness), despite birds and mammals being equally represented in the consumed biomass overall (Mendonça 2012).

Reptiles have served as an important source of protein for human populations around the world. Of all reptiles, turtles are the most heavily exploited for human consumption whereas crocodiles, snakes, and lizards may be locally important food sources (Klemens and Thorbjarnarson 1995). For some human communities in the Amazon region, reptiles, especially the chelonians, have assumed an important role in the diet of local people at a certain time of the year (see Figure 1) (Alves et al. 2011; Klemens and Thorbjarnarson 1995; Pezzuti et al. 2004; Pezzuti et al. 2008; Rebêlo et al. 2005). As noted by Alves et al. (2011), freshwater turtles were an important food source for inhabitants of the Amazon region even before the arrival of European settlers, especially during the dry season.

Although amphibians are consumed on a smaller scale than other vertebrates, there are places where these animals constitute an important part of the local community's diet. In many countries, frogs have always been collected locally, comprising an essential source of animal protein (Angulo 2008; Mohneke et al. 2010; Mohneke et al. 2009). In Africa, it is probable that amphibians have always been eaten and used for cultural purposes, with examples occurring in western Cameroon (Gonwouo and Rödel 2008) and in Gabon (Pauwels et al. 2003). Recently, Warkentin et al. (2009) summarized some alarming data on the numbers of Asian frogs collected for human consumption. 

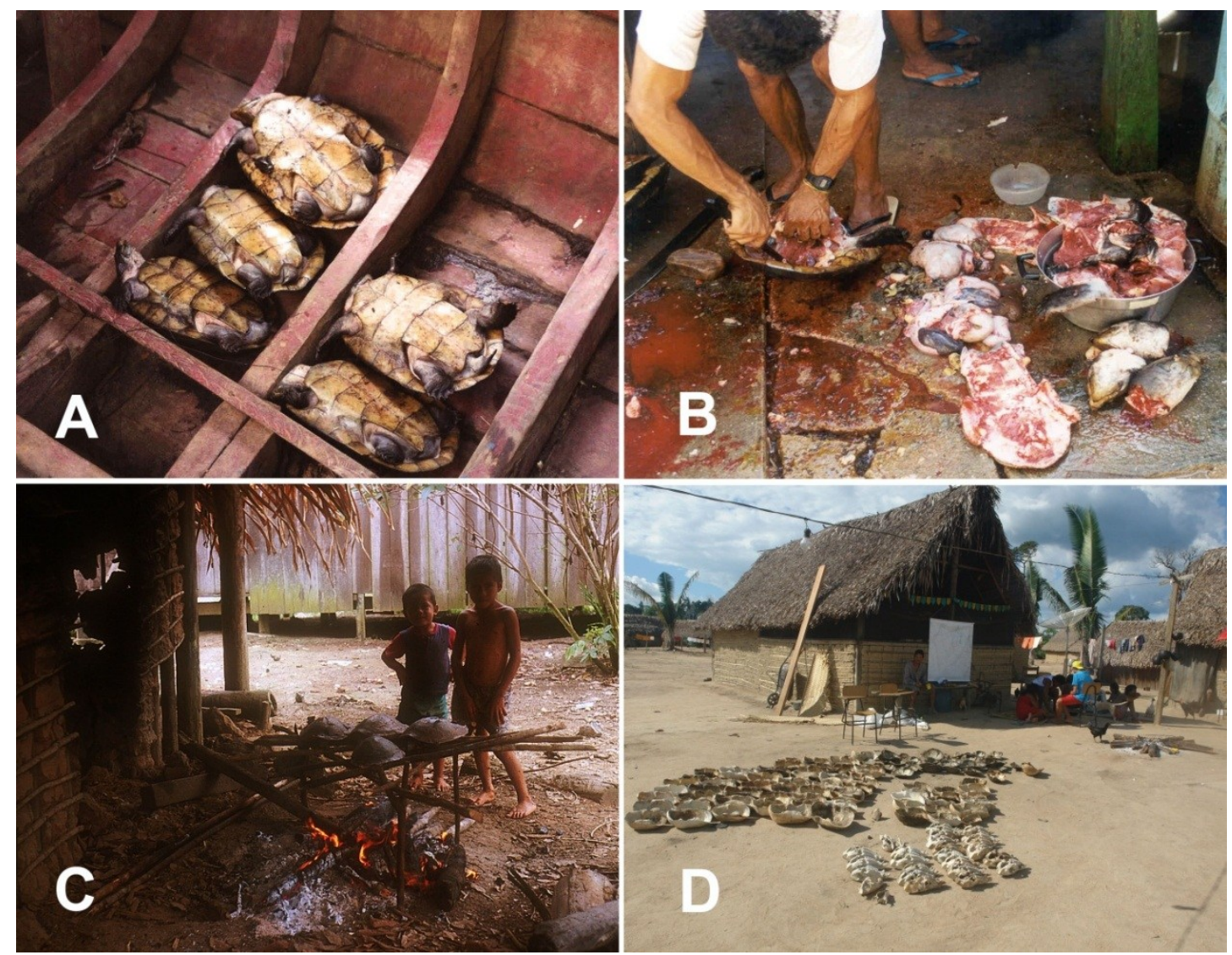

Figure 1. Scenes associated with the capture and consumption of chelonians in the Brazilian Amazon region. A - Peltocephalus dumerilianus caught in the Caurés River, to be sold in Barcelos City, Amazonas, northern Brazil; B - Slaughtering large Peltocephalus dumerilianus turtles for food, Barcelos, Negro River; C - Next meal - specimens of Podocnemis erythrocephala recently captured by 10 -year-old children in Jaú National Park, Amazonas state, Brazil; D - The skulls and shells of the peccaries and tortoises eaten by Araweté Indians living along the Ipixuna River, Xingu, Pará, northern Brazil. Photo credits: Juarez C. B. Pezzuti.

Regardless of the animal group consumed, bushmeat represents an important source of animal protein in both rural and urban areas (Alvard et al. 1997; Bailey 2000; Bennett and Robinson 2000; Nasi et al. 2008; Newing 2001; Ojasti 1997; Robinson and Redford 1991; Schenck et al. 2006). Even in societies with an agriculture- and livestock-based economy, hunting is important for many families, providing up to $80 \%$ of the meat consumed in certain rural communities (Bakarr et al. 2001). For example, the rural population from the Brazilian Amazon alone each year consumes between 9.6 and 23.5 million reptiles, birds and mammals, representing an estimated total biomass of between 67,173 to 164,692 tons, and a yield of 36,392 to 89,224 tons of wild meat (Peres 2000). In the moist forests of the Congo Basin in Africa, between one and three million metric tons of dressed (slaughtered) wild meat is eaten each year (Fa et al. 2003). Examples of vertebrate game of Neotropical region are shown in Figures 2 and 3.

The magnitude of the exploitation and consumption of bushmeat varies however from country to country and is determined primarily by its availability; it is also influenced by governmental controls on hunting, and by socio-economic status and cultural prohibitions. In areas where wildlife still persists, people either collect, hunt or purchase and eat bushmeat for a variety of reasons. Some people depend on bushmeat for their supply of animal protein because they have no alternative sources 
or cannot afford them; others eat bushmeat as a matter of preference or as a luxury item/delicacy on special occasions (Alves et al. 2009b; Fa et al. 2003; Ntiamoa-Baidu 1997).
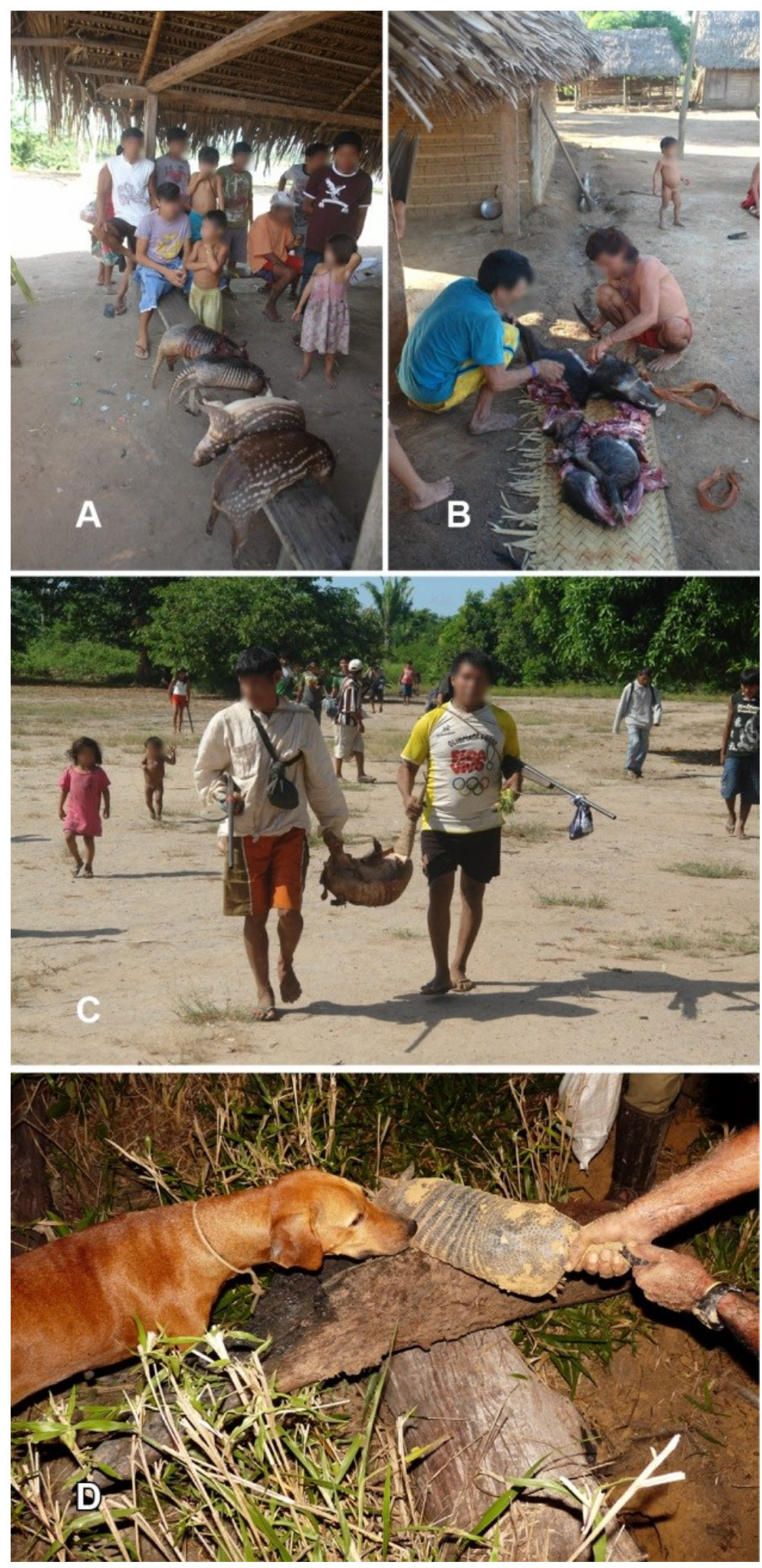

Figure 2. Examples of bushmeat hunting in Brazilian Amazon region. A - Hunted specimens of Cuniculus paca and Dasypus sp.; $B$ - Slaughtering of the peccaries Pecari tajacu; Hunting armadillo (Dasypus kappleri - C and D. novemcinctus - D). Photo credits: Juarez C. B. Pezzuti (A, B and C) and Hugo Fernandes Ferreira (D). 

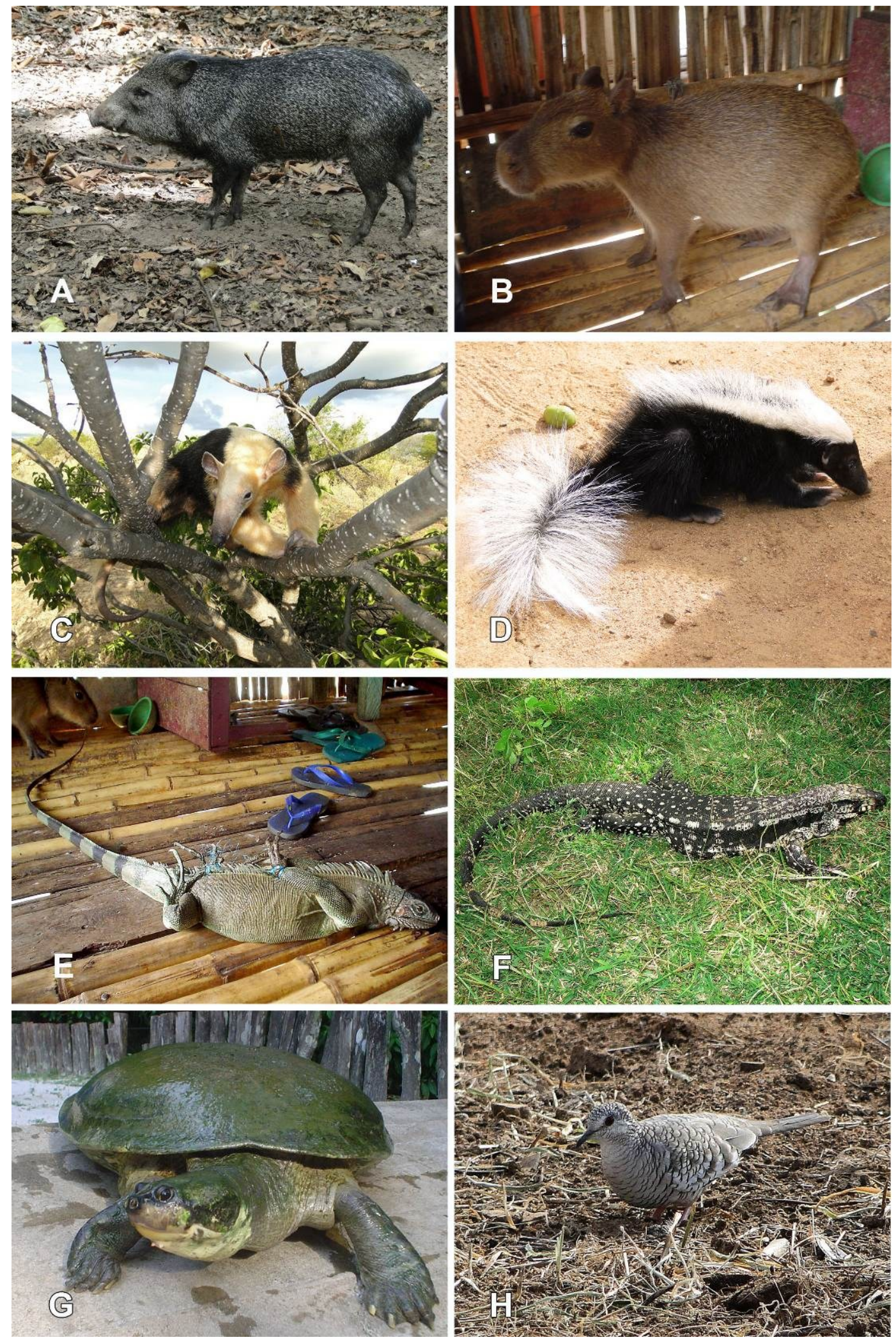

Figure 3. Some vertebrate game species of Neotropical region. A - Collared peccary (Pecari tajacu); B - Capybara (Hydrochaeris hydrochaeris); C - Southern Tamandua (Tamandua tetradactyla); DStriped hog-nosed skunk (Conepatus semistriatus); E- Common iguana (Iguana iguana); F- Tegu lizard (Tupinambis merianae); G- Giant South American turtle (Podocnemis expansa); H- Scaled dove (Columbina squammata). Photo credits: A, B, E and G- Rômulo R.N. Alves; C and D- Wedson M. S. Souto; F- Washington L. S. Vieira; and H- Dandara M. M. Bezerra. 
Like hunting, the importance of fishing for mankind has a long history. Humans have depended on aquatic resources since early in their evolution. Archaeological, historical and ethnographic data show that aquatic-based subsistence has in fact been crucial to the establishment of human populations in broad geographic areas of the world, such as the Caribbean and the insular Pacific (García-Quijano and Pitchon 2010). Practically all modern human societies that have ever existed have to some degree utilized aquatic (ocean, lake or stream) resources (García-Quijano and Pitchon 2010). From prehistoric evidence, it is known that some of the fish we still eat today were in the past taken by hook and line, with nets from the banks of rivers, from the seashore and from boats (Cushing 1988). Fisheries had their origin in inland waters. Long before people started to grow crops or raise livestock, they went fishing, initially in rivers, ponds, wetlands and lagoons. Many decades passed before people ventured onto the open waters of large lakes, or onto the sea, in purpose-built craft. Several centuries ago, marine fisheries overtook inland fisheries as the major supplier of fish protein on a global scale (FAO 2010).

Amongst the fishing resources most exploited by humans, vertebrates (fishes, reptiles, and mammals) and also invertebrates (e.g. arthropods, molluscs and echinoderms) are prominent (Figure 4). The most common use for these fisheries resources is food. Fisheries play an important role in the global provision of food (Mora et al. 2009), directly accounting for at least $15 \%$ of the animal protein consumed by humans and indirectly supporting food production through aquaculture and livestock industries (FAO 2009c; Naylor et al. 2000). Demand for fish is expected to grow given the escalating demand for animal protein in developing countries and the rapidly increasing human population (Delgado et al. 2003; FAO 2009c).

The most recent statistics (FAO 2011) report that captive fisheries and aquaculture supplied the world with approximately 144.6 million tons of fish in 2009 . Of this, 117.8 million tons were used as human food, providing an estimated apparent per capita supply of about $17.2 \mathrm{~kg}$ (Bondad-Reantaso et al. 2012). According to the FAO (2012), over $75 \%$ of global fish production is used directly for human consumption, and consumption of fresh fish is growing at the expense of other forms of fish products (e.g., canned fish).

\section{The role of fauna in human health}

The interrelationships between society and nature, and the importance of environmental health to human health, have recently become widely acknowledged (Alves and Rosa 2007; WHO 2005), drawing attention to the fact that biodiversity loss can also have indirect effects on human well-being. The links between animals and human health have been substantiated throughout the history of mankind, from causes to cure of human diseases. Five main aspects should be highlighted when considering this connection: i) animals as the cause/disseminator of diseases for humans and vice versa; ii) animal as sentinels of human health; iii) the use of animals in traditional medicine systems; iv) animals as a source of drugs; and v) use of animals in medical research. These aspects will be briefly discussed in the following text. 
Alves 2012. Relationships between fauna and people and the role of ethnozoology in animal conservation. Ethnobio Conserv 1:2
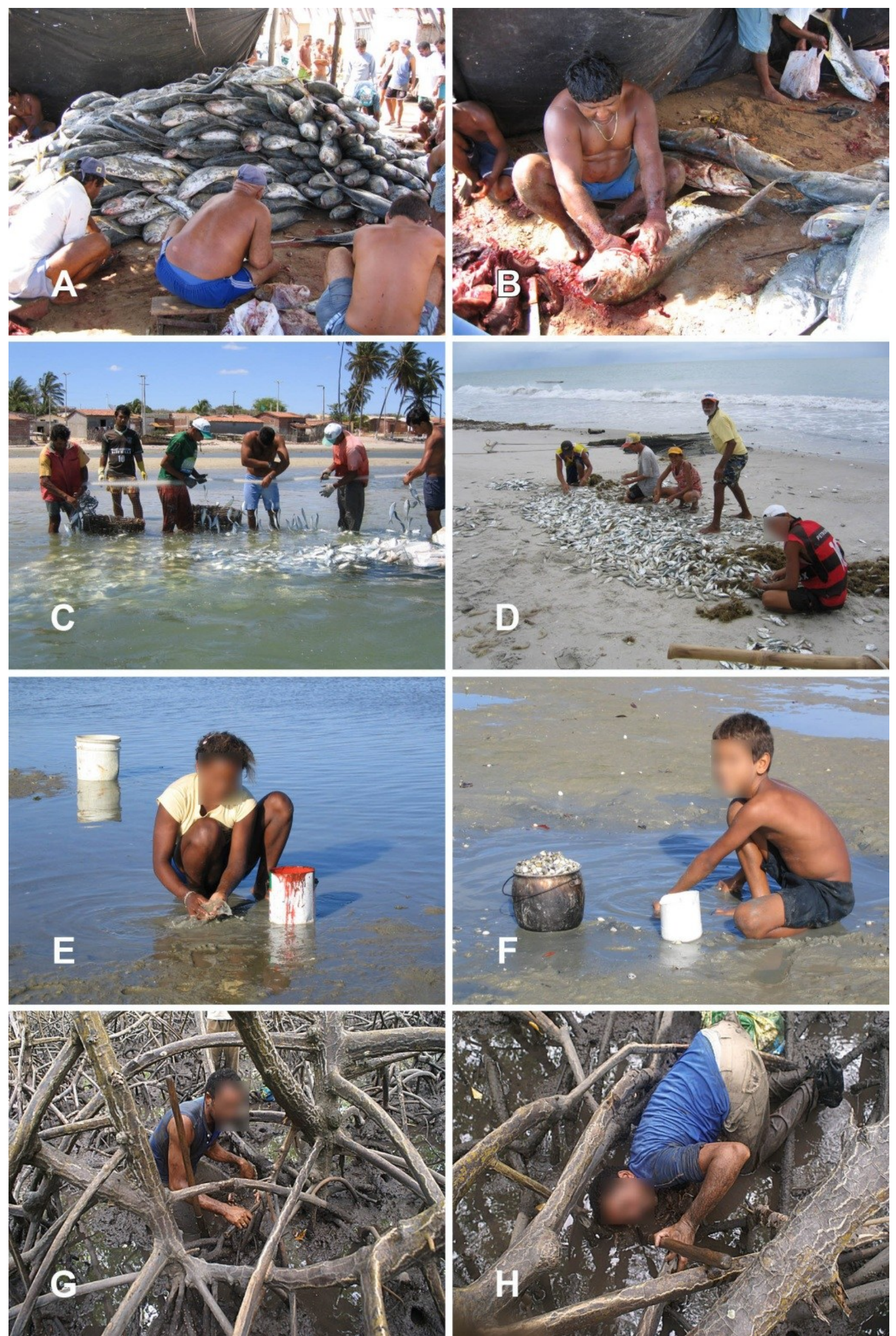

Figure 4. Examples of artisanal fishing on Northeast Brazilian coast. Fishing for Caranx hippos (A and $\mathrm{B})$ and Opisthonema oglinum ( $\mathrm{C}$ and $\mathrm{D})$; Capture of molluscs (Anomalocardia brasiliana) (E and $\mathrm{F}$ ) and crabs (Ucides cordatus) (G and H). Photo credits: A, B, C, D, E and F -Thelma L. P. Dias; G and H - José S. Mourão. 


\section{Animals as cause/disseminator of disease in humans and vice versa}

Since ancient times, human beings have related the appearance of certain diseases and epidemics to the presence or influence of animals that are considered to presage bad omens, diseases and death (Ávila-Pires 1989). This is not surprising, considering that the natural world has a strong influence on the transmission of disease to humans from animals and vice versa, and the perception of more primitive societies therefore certainly reflects daily experiences. As pointed by Wolfe et al. (2007), human hunter/gatherer populations currently suffer, and presumably have suffered for millions of years, from infectious diseases similar or identical to diseases of other wild primate populations.

When an infectious agent responsible for a human disease is also capable of infecting other species, these species may act as reservoirs or vectors for the disease (European Commission 2011). Arthropods, for example, transmit hundreds of different known infectious and parasitic agents to humans and animals around the world. These vectors include almost all forms of blood-sucking arthropods: mosquitoes, ticks, mites, biting midges, sand flies, kissing bugs, bed bugs, black flies, lice, fleas, and deer and horse flies (Seymour 1984).

Diseases and infections that are naturally transmitted between vertebrate animals and humans are known as zoonoses (Bell et al. 1988; Krauss 2003) and have been known to affect human health throughout history (Kruse et al. 2004). Such diseases have an important impact on public health and economy, and on the conservation of wildlife (Cleaveland et al. 2001). Exposure of humans to zoonoses occurs in different ways, from well-known or well-understood direct transmission routes, such as bites and rabies, to less obvious pathways, the risk factors or potential exposure routes of which are difficult to recognize and are interlinked in a relationship network between human beings, animals and the environment (Friend 2006). The most frequent sources of zoonose transmission comprise food and contaminated water, vector insect bites and scratches, or bites from infected animals (Chomel 2002).

Zoonotic diseases account for approximately $75 \%$ of emerging infectious diseases (Chomel et al. 2007; Taylor et al. 2001). A literature search showed that more than 800 human pathogens are zoonotic (Taylor et al. 2001; Woolhouse and Gowtage-Sequeria 2005). According to Weiss (2001), some of these pathogens may cause serious diseases in wild animals but, in some cases, the animals act as reservoirs, without showing any clinical symptoms (Williams et al. 2002). As mentioned above, zoonoses can be transmitted by direct contact with infected animals, dead or alive, which can be used by humans in several ways, including consumption as food or as pets. The consumption of animal products as food or in traditional medicine, for example, facilitates the transmission of serious and widespread zoonoses, such as tuberculosis or rabies (De Smet 1991; Schnurrenberger and Hubbert 1981; Still 2003). Another example deserving mention is Avian influenza (Influenza A) viruses; these are responsible for highly contagious acute illness in humans, pigs, horses, marine mammals and birds, occasionally resulting in devastating epidemics and pandemics (Bengis et al. 2004).

Wildlife constitutes an important but poorly known reservoir for many emerging infectious diseases, most of which are of zoonotic concerns (Pérez 2009). The trade in wildlife for food consumption, for medicine and as pets, among other uses, involves the capture and the sale of billions of animals of many species (Alves et al. 2010b; Alves et al. 2008; Pérez 2009). The exotic pet trade deals with an increasing 
range of wild animal species, from invertebrates to mammals (Pérez 2009). It is believed that epidemics such as SARS (Severe Acute Respiratory Syndrome), monkey-pox, and avian influenza H5N1 may have emerged from wildlife markets (Brown 2004; Burgos and Burgos 2007; Check 2004; Karesh et al. 2007; Sleeman 2006; Warwick et al. 2011).

There is a rising threat from emerging infectious diseases spreading to people and other animals, fuelled by human activities ranging from the handling of bushmeat and the trade in exotic animals to the destruction of wild habitat (Lilley et al. 1997; Patz et al. 2000; Walsh et al. 1993). Despite warnings of the potential significance for human disease of changing patterns in their relationship with animals and the natural world, scientists have continued to treat human and animal health as largely independent disciplines, while historians have also neglected this important aspect of human disease (Hardy 2003). In this sense, it is crucial that the interdependence between animal and humans be considered in the development of new public health practices.

\section{Animal as sentinels of human health}

As discussed previously, animals suffer a similar spectrum of disease to humans (see Bell et al. 1988; Krauss 2003) and, therefore, may be sensitive indicators of environmental hazards and provide an early warning system for public health intervention (Reif 2011). The concept that disease occurrence in non-human animal populations (wild and domestic) can serve as a sentinel event warning of an environmental threat to human health has a long history (Rabinowitz et al. 2005).

Studies of the effects of environmental exposure on domestic and wild animals can corroborate or inform epidemiologic studies in humans (Reif 2011). Several historical examples illustrate animals' usefulness as predictors of human illness (Reif 2011). In the 1870s, fattened cattle experienced high mortality at a stock show in London's Smithfield market associated with a dense industrial fog-a precursor to the air pollution episodes typified by the infamous London Fog of 1952, during which thousands of residents died (Glickman et al. 1991). In the 1950s, recognition of neurobehavioural disturbances in the cat population of Minamata, Japan, preceded a severe episode of neurological disease among local residents caused by consumption of seafood contaminated with methylmercury (Tsuchiya 1992). Sediments, shellfish and fish in Minamata Bay became contaminated with mercuric chloride as the result of effluent discharges from a chemical plant. The ataxic "dancing cats of Minamata" were a warning sign. Unfortunately, it was not recognized in time to prevent the human epidemic (Reif 2011). In 1962, it was cases of lead poisoning in cattle and horses living in the vicinity of a smelter that alerted the Minnesota state health department to conduct surveillance for lead exposure in local human populations (Hammond and Aronson 1964).

Animal sentinels may potentially be used to address a range of surveillance questions including: (i) detection of a known pathogen in a new area; (ii) detection of changes in the prevalence or incidence of a pathogen or disease over time; (iii) determining the rates and direction of pathogen spread; (iv) testing specific hypotheses about the ecology of a pathogen; and (v) evaluating the efficacy of potential disease control interventions (McCluskey 2003). Appropriate use of animal sentinels can facilitate the early detection and identification of outbreaks, which is of critical importance both for the success of control and prevention efforts (Chomel 2003; Kahn 2006) and for reducing the magnitude of subsequent outbreaks 
(Ferguson et al. 2005). However, the potential of animal sentinel surveillance can only be fully realized if information sourced from animal populations is acted upon. For example, an Ebola outbreak in central Africa was the result after insufficient preventive health measures were taken despite warnings of an imminent human outbreak being provided from monitoring of Ebola deaths in primate sentinels (Rouquet et al. 2005).

Currently, however, physicians assessing environmental health risks to patients do not routinely include animal sentinel data in their clinical assessments. Public health practitioners are unlikely to respond to mortality events in animals that are not clearly due to West Nile virus or other known zoonoses, such as rabies (Rabinowitz et al. 2005). Reasons for the underuse of animal sentinel data by human health professionals may include: limited understanding of the relationships existing between animal, human, and ecosystem health; insufficient knowledge of veterinary medicine; and few institutional protocols to incorporate animal data into public health surveillance (Stephen and Ribble 2001). In recent years, both human and animal health professionals have gained an increasing awareness that disease events in animal populations may have direct relevance to human health (Scotch et al. 2009).

\section{Traditional medicine}

It is known that at the dawn of recorded history humans often ate, or wore on their person, some portion of an animal that was thought to have a healing or protective influence (MacKinney 1946); this highlights the intertwining of the origin of the medicinal use of faunal elements with their use as food. In the same context, Chemas (2010) remarked that the treatment of illnesses using animal-based remedies is an extremely old practice, the most remote antecedent of which is a carnivore diet, closely followed by the ritual ingestion of deceased persons (e.g., close relatives, warriors) as a means of absorbing their virtues (e.g., courage, virility), and subsequently by a true medicinal use inseparable from magic-religious elements. These observations are in line with the view of nature as providing many things for humankind, including tools for the first attempts at therapeutic intervention (Nakanishi 1999).

Although plants and plant-derived materials make up the majority of the ingredients used in most traditional medical systems worldwide, whole animals, animal parts, and animal-derived products also constitute important elements of the materia medica (Alakbarli 2006; Alves and Rosa 2005, 2007, 2012; Moquin-Tandon 1861; Scarpa 1981; Stephenson 1832; Unnikrishnan 2004).

In modern societies, zootherapy constitutes an important alternative to the many other known therapies practised worldwide. Wild and domestic animals and their by-products (e.g., hooves, skins, bones, feathers, tusks) form important ingredients in the preparation of curative, protective and preventive medicine (Adeola 1992; Alves and Alves 2011; Alves and Rosa 2012; Ashwell and Walston 2008; Whiting et al. 2011). Many cultures still employ traditional medicine incorporating animal-derived remedies. Probably the most famous of these are the Chinese, who use animals to treat a variety of ailments. Although less known and less frequently studied, Latin America and Africa both have a long tradition of using their equally varied and rich fauna, including many endangered species, to treat all kinds of ailments. For example, in Traditional Chinese Medicine (TCM), more than 1500 animal species have been recorded as being of some medicinal use (Yinfeng et al. 1997). In India nearly 15-20 percent of Ayurvedic medicine is based on animal- 
derived substances (Unnikrishnan 1998). In Latin America, at least 584 animal species have been used in traditional medicine (Alves and Alves 2011). Zootherapeutic practices are also found in Europe (Ceriaco 2012; Quave et al. 2010; Voultsiadou 2010). Examples of animals used as medicine in Latin America is shown in Figure 5.

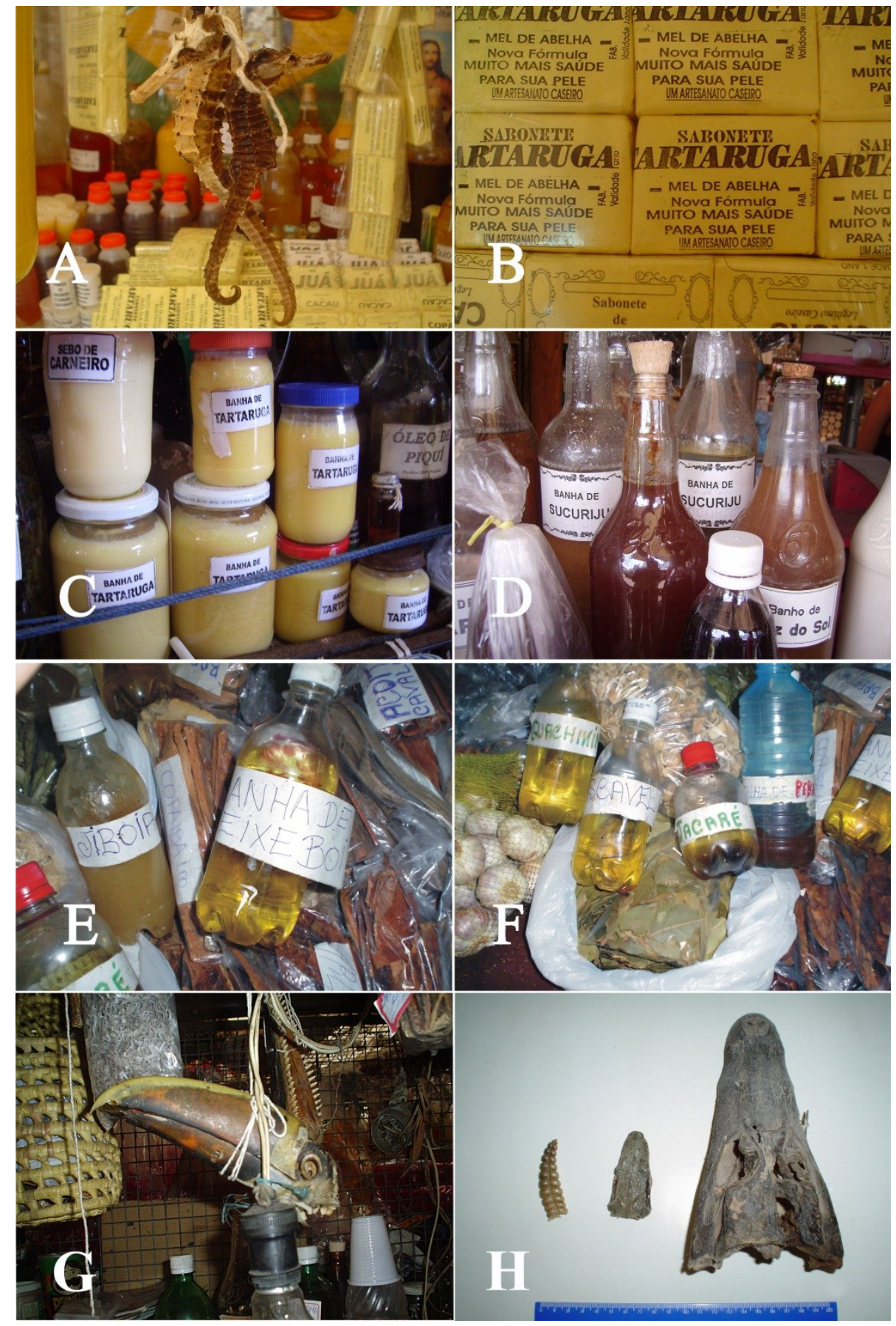

Figure 5. Examples of animal products used in traditional folk medicine in Latin America. A - Dried seahorses; B - Soap is produced from fat of the turtle Podocnemis expansa and honey bee; C - Fat derived from sheep (Ovis aries) and turtle ( $P$. expansa); D - Anaconda fat (Eunectes murinus). E Fats from boa (Boa constrictor) and manatee (Trichecus sp.); $\mathrm{F}$ - Plastic bottles with fat from raccoon (Procyon cancrivorus), rattlesnake (Crotalus durissus), cayman (Paleosuchus palpebrosus or Cayman crocodilus) and armadillo (Euphractus sexcintus);G - Ramphastos tucanus beak (Tucano); H - Rattle of rattlesnake ( $C$. durissus), boa head (B. constrictor) and cayman head (Cayman sp). Photo credits: A, B, E, F, G and H - Rômulo R. N. Alves; and C and D - José A. A. Barbosa 
Mammals, fish, reptiles, birds, molluscs and insects, including threatened species, are prominent amongst the main animals used in traditional medicine (Alves et al. 2008, 2009a, 2010b,c; Whiting et al. 2011), substantiating the importance of understanding such uses in the context of animal conservation.

The world's animals and plants-including a number of species used in traditional medicine - face threats ranging from habitat loss to the global wildlife trade (Cleva 2006). There has been an increasing demand for traditional medicines (Alves and Rosa 2007; Robinson and Zhang 2011) and, in recent years, the link between traditional medicine and the loss of certain species has become apparent (Alves et al. 2007; Call 2006). This trend bears important implications for the conservation of the many species of flora and fauna on which traditional remedies are based (Alves et al. 2007; Lee 1999; Still 2003). Unfortunately, whereas the use of traditional remedies used to be a localized practice, the globalization of commerce in combination with the increased popularity of natural approaches to health worldwide has created a level of demand that threatens the survival of many vulnerable species of wildlife (IFAW 2011).

Medicinal use of fauna represents an additional pressure for many species, and has been indicated as an important cause of population decline. Thus, not only should the use of these animals in popular medicine be considered, but also their exploitation by the pharmaceutical industry (Marques 1997). As Shaw (2008) points out, any pharmaceutical scientist who is involved in contemporary natural product research has to get involved in, or at the very least become familiar with, global issues of species conservation and/or biodiversity.

\section{Fauna as source of drugs}

Throughout human history, people have used various natural materials to cure their illnesses and improve their health (Alves et al. 2010c; Alves and Rosa 2007). Wildlife not only contributes to traditional medicine but also modern medicine, with natural extracts being used by pharmaceutical companies as raw material for the manufacture of drugs (Sifuna 2012). Historically, while the use of plants as medicines has been extensively recognized, studied and reviewed, studies on the use of fauna as a source of drugs have only been produced in recent decades, and have demonstrated the enormous potential of fauna as a source of natural products and drugs (Alves and Albuquerque 2012b; Alves and Rosa 2012).

Several recent studies have shown that natural animal resources are highly promising in the search for new products of medicinal or pharmaceutical interest (Alves and Albuquerque 2012b; Chivian 2002; Dossey 2010; Fusetani 2000). This potential is perhaps even greater for animals than for plants, considering that the number of animal species is several times greater (Alves and Albuquerque 2012a). For example, Trowell (2003) points out that there are at least 16 times as many insect species as there are plant species, yet plant chemistry has been studied 7000 times more than insect chemistry, based on a comparison of the amount of research undertaken per species. In addition, various other groups of terrestrial animals, particularly reptiles and amphibians, have been of great interest in pharmacological studies. Marine animals also represent an exceptional source of bioactive natural products, many of which exhibit structural features not found in terrestrial natural products (Faulkner 1998; Ireland et al. 1993).

There has been increasing attention paid to animals, both vertebrates and invertebrates, as a source for new medicines (Chivian 2002). Animals have been 
methodically tested by pharmaceutical companies as sources of drugs for modern medical science (Kunin and Lawton 1996), and the current percentage of animal sources for producing essential medicines is fairly significant. Of the 252 chemicals selected as essential by the World Health Organization, $11.1 \%$ are derived from plants and $8.7 \%$ from animals (Marques 1997). Of the 150 prescription drugs currently in use in the United States of America, 27 have an animal origin (World Resources Institute 2000). Although the potential of faunal biodiversity is well-known, a careful strategy is required if species are to be exploited sustainably. One of the main conservation concerns about the exploitation of fauna in the search for bioactive compounds is the possible overharvesting of target organisms (Alves and Albuquerque 2012b). Some taxa with known pharmacological potential are especially susceptible to overexploitation; for example, marine species such as cone shells and molluscs have been overharvested as sources of clinical neuropharmaceuticals (Sukarmi and Sabdono 2011). Harvesting of reef organisms for the discovery and development of pharmaceuticals is causing increased concern, since it has been perceived by many as unsustainable and a threat to conservation (Hunt and Vincent 2006; Sukarmi and Sabdono 2011).

\section{Animals in biomedical research}

In addition to their use in traditional medicine and as a source of medicinal drugs, animals are essential to research the results of which have either direct or indirect implications for human health. Animal experimentation in the context of scientific research has contributed greatly to the development of science and technology, promoting over time the discovery of prophylactic measures and treatments for diseases that attack humans (Chorilli et al. 2009).

Although research using animals has been intensified during the last century, it is known to have occurred since ancient times. There is a record of animal experimentation from ancient Rome, but not until the Renaissance did scholars begin serious study of how the body works. Leonardo da Vinci (1452-1519) and other artists and anatomists pursued anatomical investigations of muscle and bone structure. William Harvey (1578-1657) discovered the circulation of the blood through his experiments on live deer. During this period, much of the live animal experimentation, both in England and France, was based on the view of the French philosopher, René Descartes (1596-1650), that animals are incapable of feeling pain. Nineteenth century French physiologist, Claude Bernard (1813-1878)—and his teacher, François Magendie (1783-1855)—conducted wide-ranging animal experiments including surgery, use of drugs, and removal of body parts from many species (Bishop and Nolen 2001).

From ancient to modern times, the use of animals in research has become one of the most important ways to better understand aspects of the anatomy, biochemistry, genetics, nutrition and physiology of humans. Additionally, knowledge of the transmission mechanisms and treatment of human diseases are associated with such research. According to Bishop and Nolen (2001), many, if not most, of the spectacular innovations in medical understanding and treatment of today's human maladies have been based on research using animals.

Approximately 35 million animals are used worldwide in research each year, some of them dogs and cats, though $90 \%$ are laboratory rats, mice and birds. A "dynamic tension" exists between supporting scientific enquiry, mostly to alleviate human disease, and acknowledging public concern about animal suffering (Bishop 
and Nolen 2001). Animals are used, for example, to: develop new surgical techniques; test the efficacy and possible side effects of new drugs; determine the preventative and curative virtues of new medicines against diseases; test the safety of new chemicals used in the food industry; and check the quality of new batches of drugs and medicines (Bowman 1977). The discovery of antibiotics, analgaesics, anaesthetics and antidepressants, the success of organ transplant development, catheterization, cardiac pacemaker and several other surgical techniques, practically all research protocols about safety, toxicity, effectiveness and quality control of new drugs-all these pass through the use of laboratory animals. Other examples of scientific contributions arising from studies of animals are the discovery of insulin, the development of vaccines against several diseases and serum production (Fagundes and Taha 2004).

\section{Animals as pets}

Primitive people found that human-animal relationships were important to their very survival, and pet keeping was common in hunter-gatherer societies (National Institutes of Health 1987). Ancient cultures around the world are known to have caught, kept, and bred animals as pets (Carrete and Tella 2008; Collar et al. 2007). This close relationship has made animals valued members of human society and has contributed to the formation of effective links with certain animals, with many species being kept (and still being kept) as pets. According to Franklin (1999), the use of animals as pets is the closest and most humanized of human-animal relationships.

The closeness of the relationship between humans and their pets has peaked since domestication became a part of human culture (Bueno 2009). Considering that domestication is invariably associated with some form of captive or controlled breeding, it is possible that the species we now classify as "domestic" were simply those that bred most readily as pets within the hunter-gatherer milieu (Serpell 1990). Nevertheless, Digard (1990) takes perhaps the broadest view of domestication, proposing a definition that includes not only pets but also animals captured from the wild for human use that do not breed in captivity.

Historical documents reveal that native peoples frequently capture young animals of various kinds, and rear them as favourites, and then might either sell or present them to colonizers and visiting naturalists as curiosities (Alves et al. 2012). Indigenous people traditionally kept and used animals in South America, and when Columbus first arrived in the New World he and his crew were met by natives offering skeins of spun cotton and wooden spears tipped with stingray tails, as well as live parrots. Since that first contact, parrots and macaws have featured in the domestic and international trade in live birds (Thomsen and Brautigam 1991). In Brazil, analyses of historical documents indicate that Indians have kept song and ornamental birds since ancient times because of their beauty, songs and companionship; and bird-keeping is firmly entrenched in local cultures and traditions (Alves et al. 2012; Carvalho 1951). Native birds and other animals were sent from colonial Brazil to Portugal throughout three centuries of continuous commercial transactions for amusement or study (Ribeiro 2006). The commercialization of wild animals was not viewed as being illicit in this period, and there are records of many commercial orders being placed in official correspondence (Ribeiro 2006). Not less than 72 non-European bird species were offered in the bird trade in Central Europe in 1794 (Bezzel and Prinzinger 1990). 
The great variety of animals kept as pets throughout the world includes not only innumerable mammals, birds and fish, but also reptiles and amphibians (Figures 6 and 7) (Alves et al. 2011, 2012; Fitter 1986; Franke and Telecky 2001; Jepson and Ladle 2005). Although there is a preference for mammals (mainly dogs and cats) and birds, others animals such as reptiles, amphibians and some groups of invertebrates have become increasingly common as domestic pets. Hoover (1998) notes that reptiles are being widely commercialized due to their relative abundance, the wide variety of species that can be acquired, the development of better techniques for raising them in captivity, the growth in the number of restrictions concerning the commercialization of other species of animals and, principally, because of the fact that they generally require less care than mammals or birds.

The ancient and deep-rooted desire for the companionship of animals has recently been shown to be a vital factor in maintaining the mental health and general wellbeing of lonely old people (Fitter 1986). The practice of utilizing animals within therapy dates back to the late eighteenth century, when animals were introduced into mental institutions to help socialize patients with mental disorders (Serpell 2006). Interestingly, one of the earliest recorded uses of animals in health care is by the founder of modern nursing. In 1860, Florence Nightingale (1969) observed that "a small pet is often an excellent companion for the sick, for long chronic cases especially". She suggested the use of a caged bird as the only pleasure an invalid who had been confined for years to the same room might enjoy (Jorgenson 1997). The first recorded setting in which animals were used therapeutically was the York Retreat in England (Netting et al. 1987). This retreat, founded in 1792, incorporated small animals such as rabbits and poultry which were cared for by psychiatric patients. This practice was initiated in response to the recently more enlightened approach of caring for the mentally ill in an attempt to decrease the use of harsh drugs and restraints (Jorgenson 1997).

Recent studies indicate that companion animals provide important physical, mental and emotional benefits to humans (Brodie and Biley 1999; Jorgenson 1997; Matuszek 2010; Netting et al. 1987). Animals are used to ameliorate human health conditions through pet therapy or animal-assisted therapy. Both domestic and domesticated animals accompany medicinal usage as co-therapists, as they may improve different forms of debilitating illnesses or mental deficiencies (Silveira 1998). Contact with animals has proven to be an efficient method to stimulate and help individuals with mobility problems, mental disabilities or behavioural problems. When playing with pets such as dogs, rabbits, and cats, children learn how to command respect, how to develop and how to face new changes and situations (Pentenero 2001). It is important to highlight, as discussed earlier, that pet-keeping can lead to serious disease and fatalities in human but, in general, the risks of pet-keeping are small, and serious illnesses and fatalities caused by them are rare (Kirkwood 1987). Captive-bred pets add greatly to human happiness and are no threat to wild stocks (Fitter 1986). However, the use of many wild species as pets has stimulated the trade of animals (Figure 7), with a consequent impact on the populations of many exploited species (Alves et al. 2012; Andrews 1990; Broad 2001). At the present time, birds represent the most traded group of all the animals involved in the traffic in wild animals. This preference is associated with the fact that birds have always been of great interest to people due to their strong colours and vocal repertoire (Alves et al. 2012; Fernandes-Ferreira et al. 2012a; Jepson and Ladle 2005; Nash 1993; Shepherd et al. 2004; Thomsen and Mulliken 1992). 

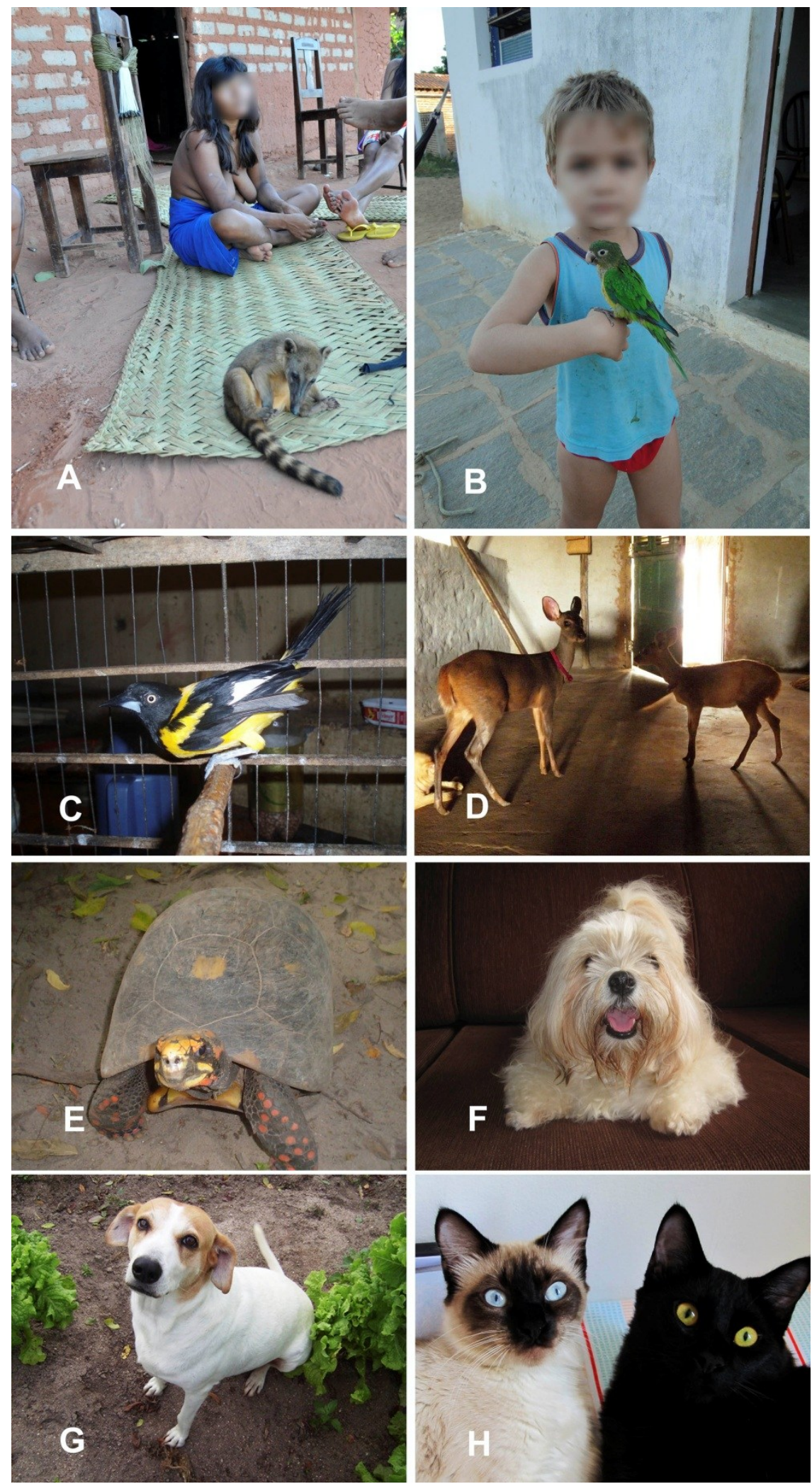

Figure 6. Examples of wild and domestic animals used as pets in Brazil. A and B- South American coati (Nasua nasua) and Caatinga parakeet (Aratinga cactorum) bred as pets in an indigenous village and a rural area in Northeast Brazil, respectively. Other pets: C- Campo Troupial (Icterus jamacaii), D - Mazama americana (red brocket- left) and Mazama gouazoupira (gray brocket- right), F- red-footed tortoise (Chelonoidis carbonaria), $\mathrm{F}$ and G- Domestic dog (Canis lupus familiaris), and $\mathrm{E}-$ domestic Cat (Felis catus). Photo credits: A and D - Hugo Fernandes Ferreira; B and E- Rômulo R. N. Alves; CLívia E. T. Mendonça, F - Tâmara P. R.Oliveira, G- Maine V. A. Confessor and E- Thelma L. P. Dias. 

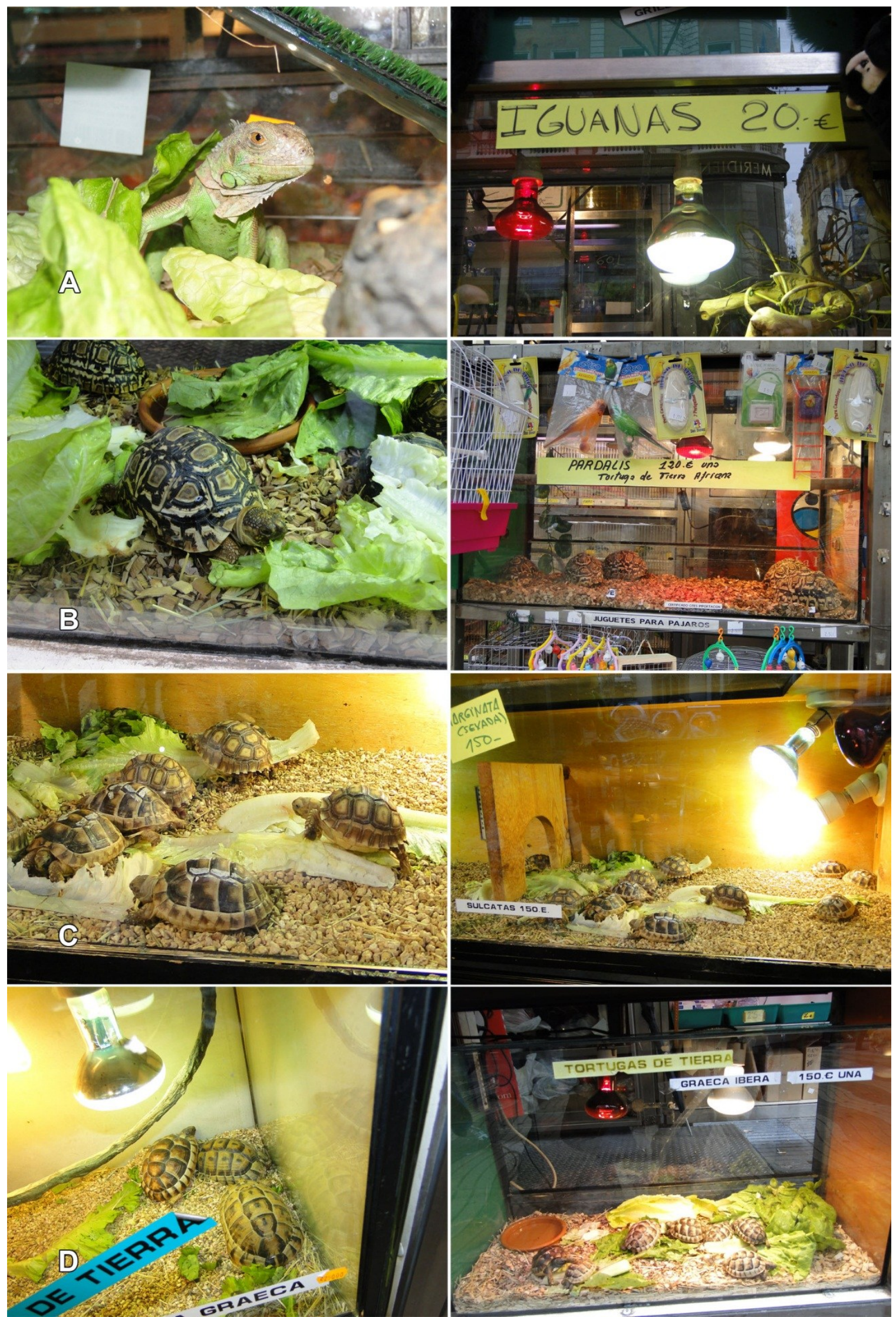

Figure 7. Pet reptiles (and their respective prices on the right) for sale in Las Ramblas, Barcelona, Spain. A - Common iguana (Iguana iguana); B- Leopard tortoise (Stigmochelys pardalis); C- African spurred tortoise (Geochelone sulcata); D - Yellow-footed tortoise (Chelonoidis denticulata); E Mediterranean spur-thighed tortoise (Testudo graeca). Photo credits: Tacyana P. R.Oliveira. 


\section{Animals in symbolism, myth, religion, magic and art}

Animals are valuable to people not only because they provide economic benefits, but because they have also been incorporated into our sense of place and are enshrined in long-standing cultural practices (Shepard 1996). The cultural importance of animals has been reflected in art, literature, symbolism, mythology and religion, among other important cultural aspects of humanity (Kalof and Resl 2007; Kothari 2007; Malamud et al. 2007; Resl 2007; Senior 2009). Klingender (1971) highlighted that at all periods animals have been used by humans in art and literature to symbolize religious, social and political beliefs, and artists have found constant inspiration in the grace and beauty of animal forms.

Among the most relevant cultural features, religious beliefs and practices have long influenced human perception and use of natural resources (Berkes 2001; Tomalin 2004). Animals have played and continue to play an important role in religious practices worldwide (Alves et al. 2009b; Berkes 2001; Leo Neto and Alves 2010; Léo Neto et al. 2009; Leo Neto et al. 2011, 2012; Lugira 2009; McNeely 2001; Nikoloudis 2001; Tomalin 2004), and their relationship with humans has encompassed a supernatural dimension since ancient times (Alves and Souto 2010). Animals have always played a prominent role in the history of religions. On the basis of the ethnographic record and knowledge of ancient religions, specialists have concluded that animals were considered to be both ancestors and protectors, and played a central role in the magic-religious behaviour of traditional societies. It has also been suggested that the cult of animals-termed "totemism"-was the earliest form of religion, and as such universally known (Alinei 2000). Totemic ideas and practices reveal animals playing key roles in the identity construction of individuals, clans, and ethnic groups (Olupona 1993).

Over millennia, anthropomorphic goddesses and gods slowly replaced animal deities. The more archaic divinities, however, accompanied their more human successors, often as mascots or alternate forms. Athena, for example, was pictured with an owl, Zeus with an eagle; Odin was accompanied by ravens and by wolves; Mary, mother of Christ, was often shown with a dove. The monkey-god, Hanuman, who fought alongside the hero, Rama, in the epic Ramayana, is now perhaps the most popular figure in the Hindu pantheon. There is something of an archaic mothergoddess in the "wicked witch" of Halloween, pictured with a faithful spider at her side (Sax 2002).

Figures that blend human and animal features became common with the transition from hunting and gathering to agriculture. The gods and goddesses of ancient Egypt often had a human torso and the head of an animal-crocodile, baboon, jackal, cat, falcon, or ibis. The Greeks had their centaurs and satyrs, while the Hebrews had cherubim and seraphim. Garuda, the carrier of the Hindu god, Vishnu, had the torso and face of a man but the wings and beak of an eagle. Yet another fantastic animal was al-Borak, the steed on which Mohammed made his flight to Heaven; she had the body of a horse and the face of a woman, and she could see the dead (Sax 2002).

At a greater or smaller scale, the magic-religious importance of animals has persisted until the present day, and varies greatly among different cultures and their religious practices. Belief in the spiritual value of nature is most often associated with indigenous people (Basso 1996; Berkes 2008; Callicott 1994; Cruikshank 2005), but is common to major religions and also many people with no religious affiliation (Haggan 2011). From ancient times to the present, many species were and remain 
associated with religious practices; animals considered as sacred, zoomorphical or anthropozoomorphical gods continue to be worshiped, and are involved in religious rituals; and products from dead animals are used to decorate altars and religious temples in different countries of the world (Adeola 1992; Alves et al. 2009a; Chan 2006; Leo Neto and Alves 2010; Léo Neto et al. 2009; Leo Neto et al. 2011; Leo Neto et al. 2012). Animals serve in sacrificial offerings, their body parts are integral parts of magical amulets and nasal ablutions, and their form and function take on profound symbolic significance-good or evil, powerful or meek, clever or dull (Moazami 2005).

The release of captive wild animals for spiritual or religious purposes is commonly practised in many parts of eastern and southern Asia (Gilbert et al. 2012). Known as merit release, "prayer release" or by the Chinese name of Feng Sheng, the activity is rooted in Buddhist teachings, although the followers of other belief systems also participate to a lesser degree (Ahmed 1997; Chan 2006; Liu et al. 2012; Severinghaus and Chi 1999). Within Buddhism, the liberation of animals from captivity is believed to be the most powerful means of attaining spiritual merit (Zangpo 2005). Practitioners believe that relieving suffering and prolonging life will enhance personal karma, promoting advancement to a state of enlightenment. However, in many places, this act of benevolence has given rise to a commercial trade through which wildlife (primarily birds, fish and turtles) are captured solely for the purpose of merit release (Chan 2006; McClure and Chaiyaphun 1971; Schoppe 2008). The ethics of supplying animals specifically for the purpose of release has been questioned on the grounds of animal welfare, ecological impact and health (Shiu and Stokes 2008). The release of non-indigenous species can lead to the establishment of self-sustaining populations, with potentially deleterious effects on local ecology. The red-eared slider (Trachemys scripta), for example, a species that is commonly sold for release purposes (Goh and O'Riordan 2007), has become the most abundant freshwater chelonian in many parts of Asia (Ramsay et al. 2007).

Further evidence of the importance of animals in religious practices is the architecture and ornamentation of religious temples, many of which depict either real or imaginary animals, as can be observed in historic churches all over the world, especially in Europe, testifying that animals occupied an important position at the time. The external architecture of many churches incorporates animal figures, as also does the internal decoration (Figures 8 and 9), as recorded by Garcia (2012), for the Sé Cathedral, São Paulo, Brazil, where sculptures of animals from the Brazilian fauna such as armadillos, egrets, lizards and toucans are found inside the building (Figure 8).

In addition to religious influences, the cultural significance of animals to mankind is richly illustrated in history. There are many types of stories, fables, folk tales, legends, myths and proverbs that have been generated from relationships between human and other animals, and which also have been passed from generation to generation through oral traditions. The influence of animals is also evident in cultural and artistic manifestations. Cave paintings, mostly representing animal figures, can be considered as the first expressions of human art. In the earliest days, people drew pictures of animals on cave walls, rocks, and pottery. These animals existed as symbols capable of transmitting cultural meanings both to those who drew them as well as for those who came long after (Spears et al. 1996). The artistic renditions conveyed to the observer the cultural meanings that the animals represented for the civilization. For example, the early cave paintings at Lascaux and Altamira portray a sense of awe for the animal (Baky 1980). The 
figurative representation of wild animals is, of course, a process of great antiquity, as the many examples of rock art and cave painting around the world demonstrate (Beardsworth and Bryman 2001). Chauvet, in southeast France, is the most ancient; some of its vivid panels of horses, lions, and rhinoceros are as much as 31,000 years old (Chauvet et al. 1996).
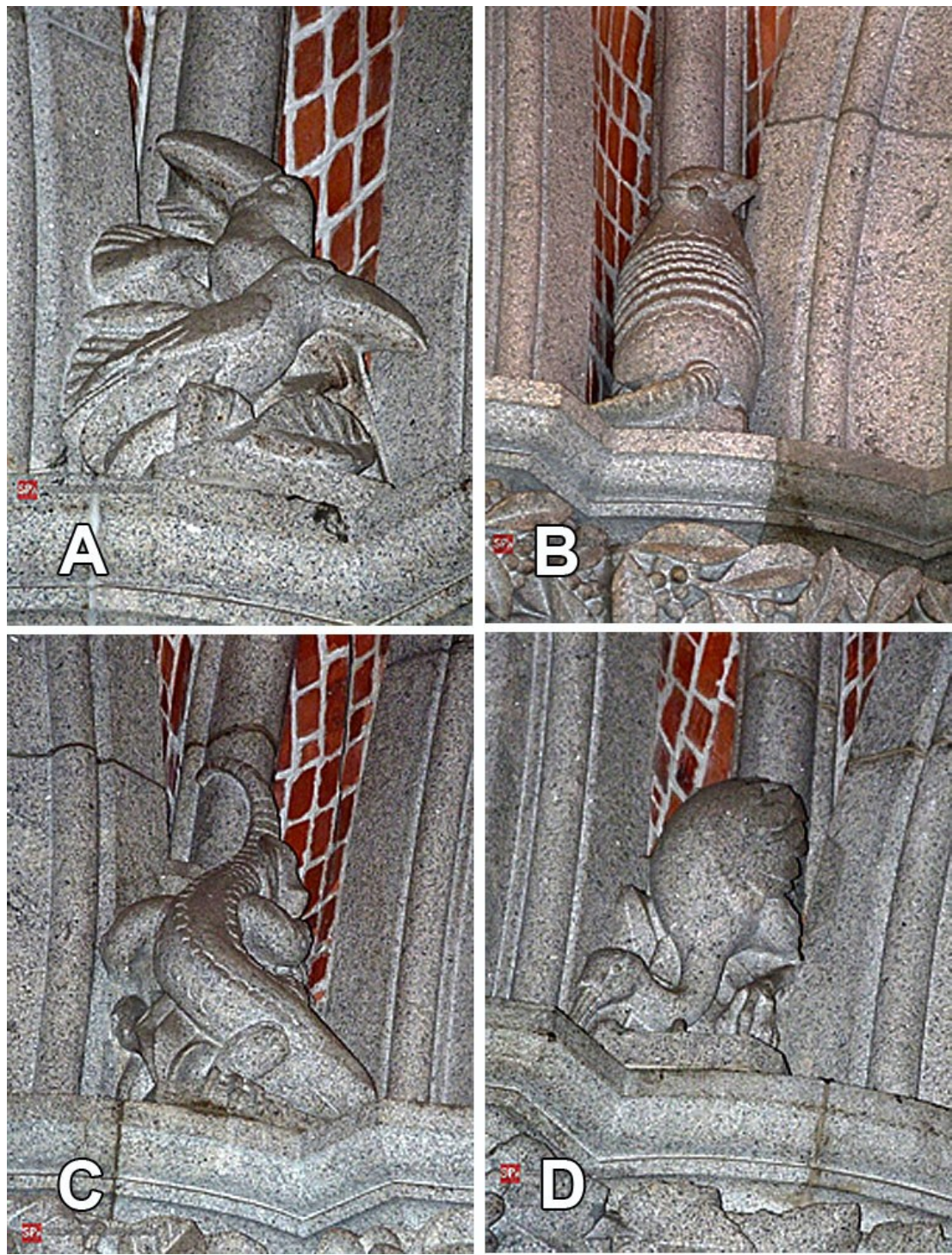

Figure 8. Sculptures of animals from the Brazilian fauna (A-toucans, B - armadillos, C - lizards and D - egrets) as part of the inside decoration of the Sé Cathedral, São Paulo, Brazil. Photo credits: Douglas Nascimento.

As human cultures evolved, representations of wild creatures, in literary, artistic and symbolic terms, became ever more elaborate and sophisticated (Beardsworth and Bryman 2001). Through time, animals have appeared in paintings, literature, music, dance, sculptures, carvings and prints. Testimonies to the importance of animals are abundant in museums of natural history and art, in books, in historical and modern buildings which portray animals in their architecture, and in squares and public places from different cities in the world, where animal sculptures are so often easy to find (Figures 10 to 17).

In music, animal sounds have been a source of inspiration for composers, as well as a direct source of music (Clark and Rehding 2001; Turner and Freedman 
2004). As recently as the 1500s, some people believed that the origin of music had its roots in animal song and other natural sounds (Turner and Freedman 2004). Links between animals and music include the documentation of songs of various animals in musical notation (Clark and Rehding 2001; Clark 1879; Mathews 1910), and theories of the development of melodious bird songs from the harmonic structure of singlenote sounds (Clark 1879). Many musical compositions have described animals in their lyrics; their skills are glorified or animal features are attributed to humans. In the same way as in music, animal movements have inspired dance in many human communities. There exist today dances in which behaviours of apes and other animals are imitated by humans-for example, among the aboriginal peoples of Australia and Africa-and such dances could have existed in the evolutionary past when Homo erectus acquired the cognitive capacity for deliberate imitation(Francis 1991).
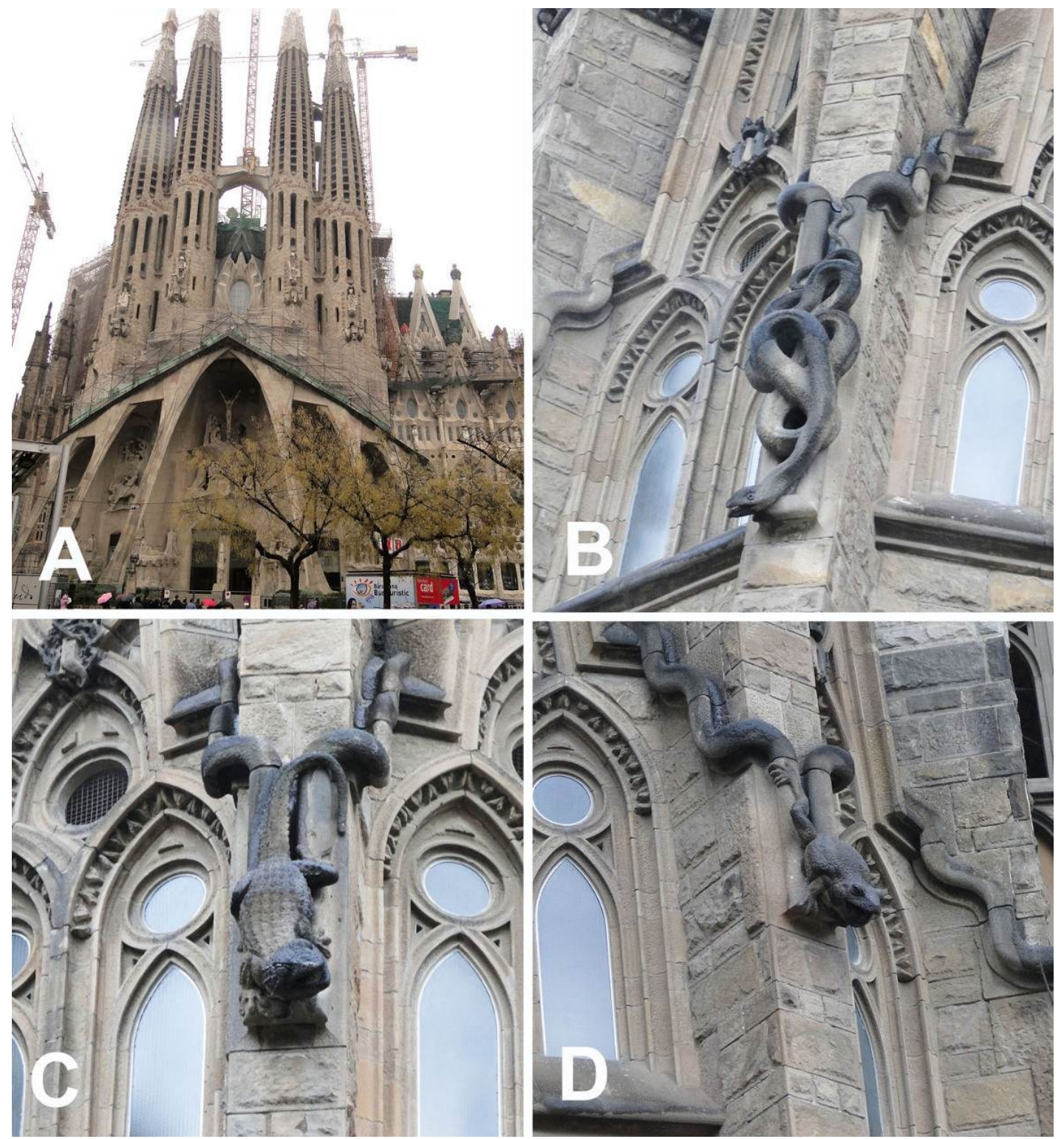

Figure 9. Cathedral of the Sacred Family (Sagrada Familia), Barcelona, Catalonia, Spain (A), with faunistic decorative element in its external architecture (B- snakes, C- lizards and D - frogs) serving as rain spouts. Photo credits: Rômulo R. N. Alves. 
Alves 2012. Relationships between fauna and people and the role of ethnozoology in animal conservation. Ethnobio Conserv 1:2
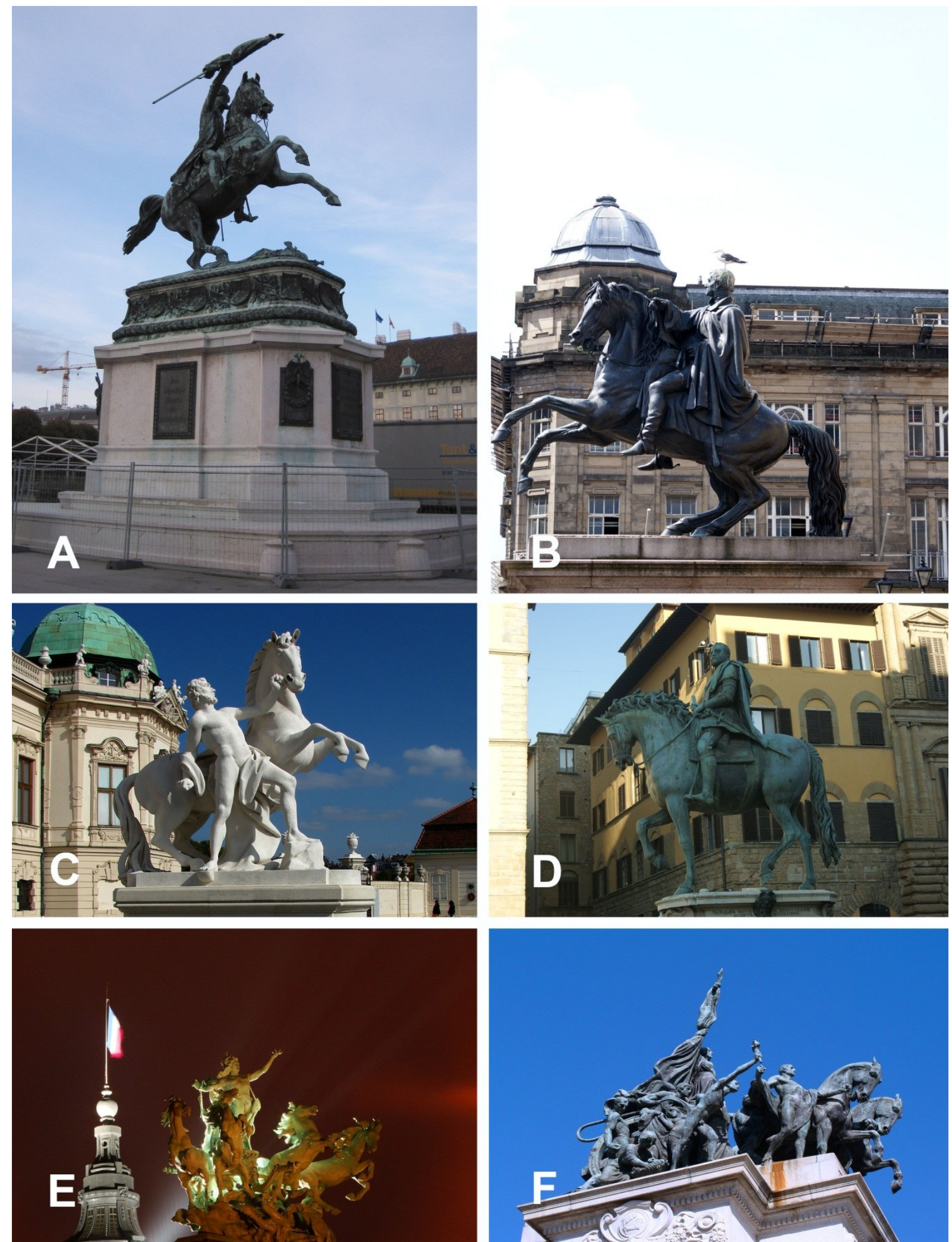

Figure 10. Equestrian statues in some cities of the world. A and C - Vienna, Austria; B- Edinburgh, Scotland; D - San Gimignano, Italy; E - Paris, France; F - São Paulo, Brazil. Photo credits: A - Rômulo R. N. Alves; B- Priscila F. L. MacCord; C- Maria S. Pereira; D - José S. Mourão; E - Edgley A. César; and F- Kleber S. Vieira. 


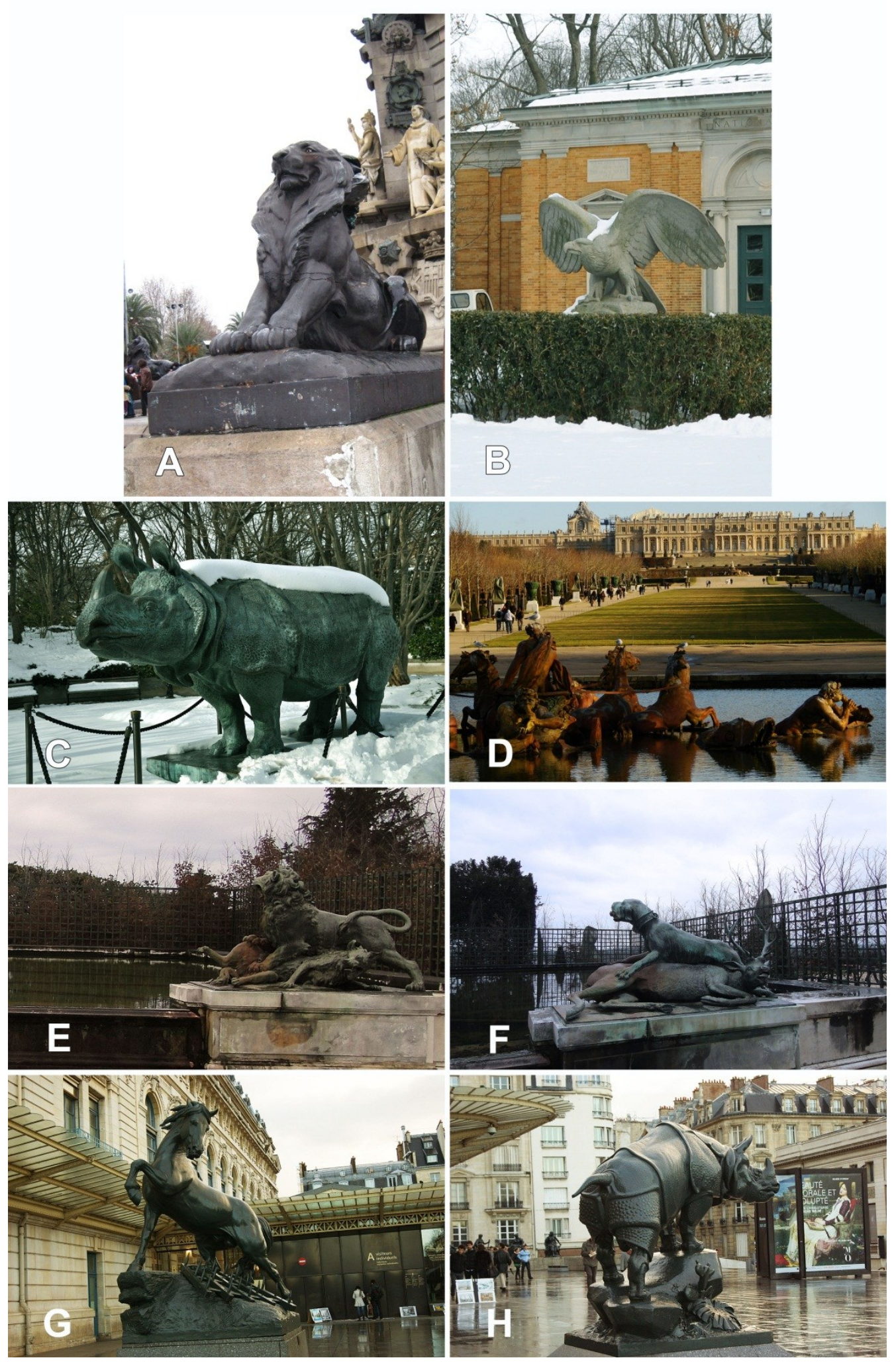

Figure 11. Examples of zoomorphic sculptures and statues. A - Lion statue at the base of the Columbus monument, Barcelona, Spain; B and C- Eagle and great Indian rhinoceros statues at the Bronx Zoo, New York, USA; Apollo Fountain (D) and animal sculptures (E and F) in Gardens of Palace of Versailles, Versailles, France; $G$ and $H$ - Statues of a horse and rhinoceros near the entrance to the Musée d'Orsay, Paris, France. Photo credits: A, E and F - Rômulo R. N. Alves; B and C- Itamar Barbosa; D - Edgley A. César; and G and H - José S. Mourão. 


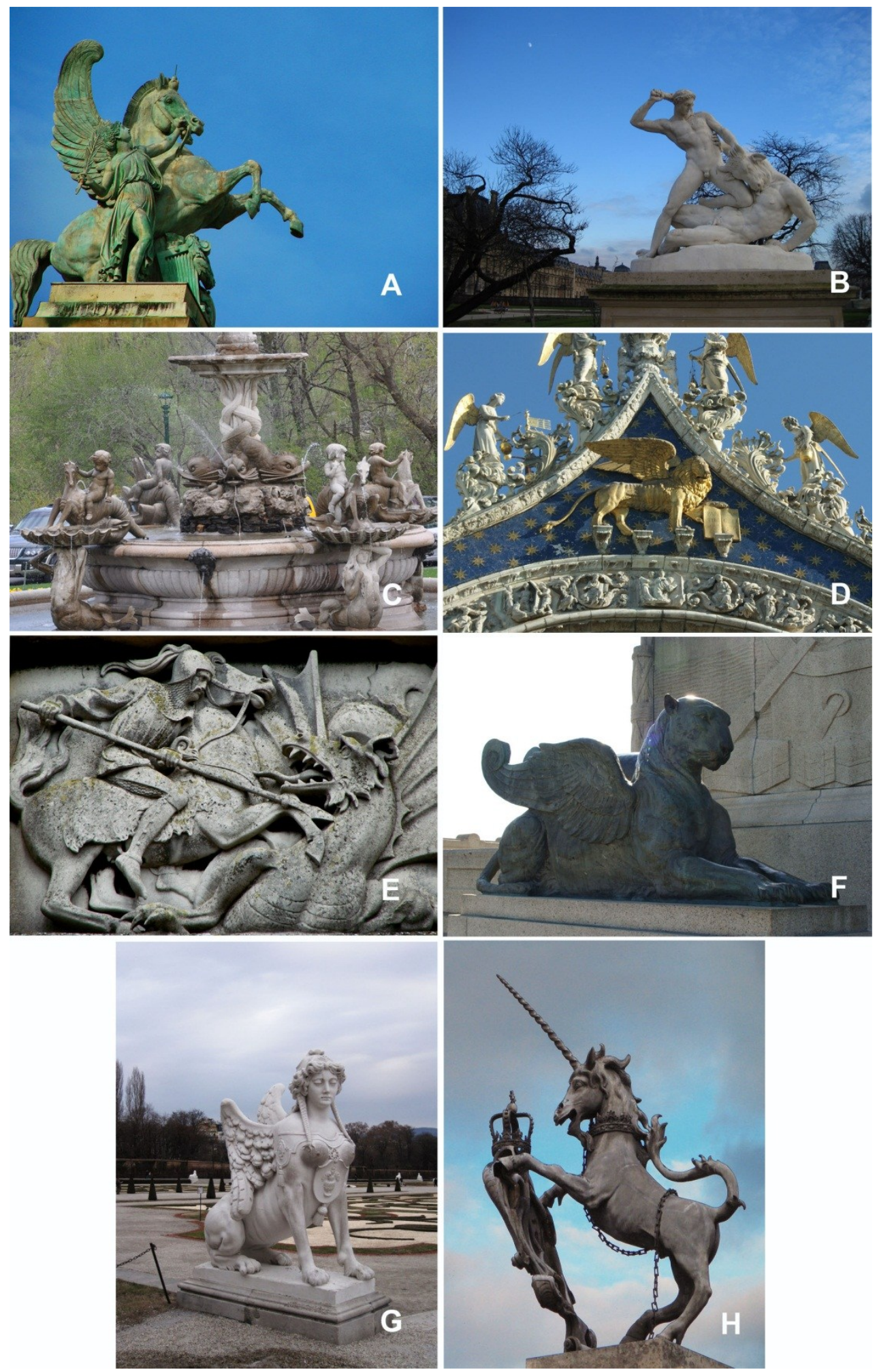

Figure 12. Mythical animal sculptures and statues decorating public spaces in some cities. A Pegasus sculpture on the roof of the Palais Garnier or Opera National de Paris, France; B- Statue of Theseus fighting the Minotaur in the Tuileries Gardens, Paris, France; C - Mythical animal sculptures in Rockefeller Fountain, Bronx Zoo, New York, USA; D - Winged lion, mascot of Venice, Italy, on top of San Marco Cathedral; E - Sculpture of St. George slaying the dragon at Windsor Castle, London, England; F- Winged lion in the Praça do Ipiranga, São Paulo, Brazil; G - Sphinx statue in Castle Belvedere gardens in Vienna, Austria; $\mathrm{H}$ - Unicorn statue at Hampton Court Palace, London, England. Photo credits: A, E and H - Edgley A. César; B - Rômulo R. N. Alves; C- Itamar Barbosa Lima; D José S. Mourão; G - Tacyana P. R. Oliveira; F - Kleber S. Vieira. 

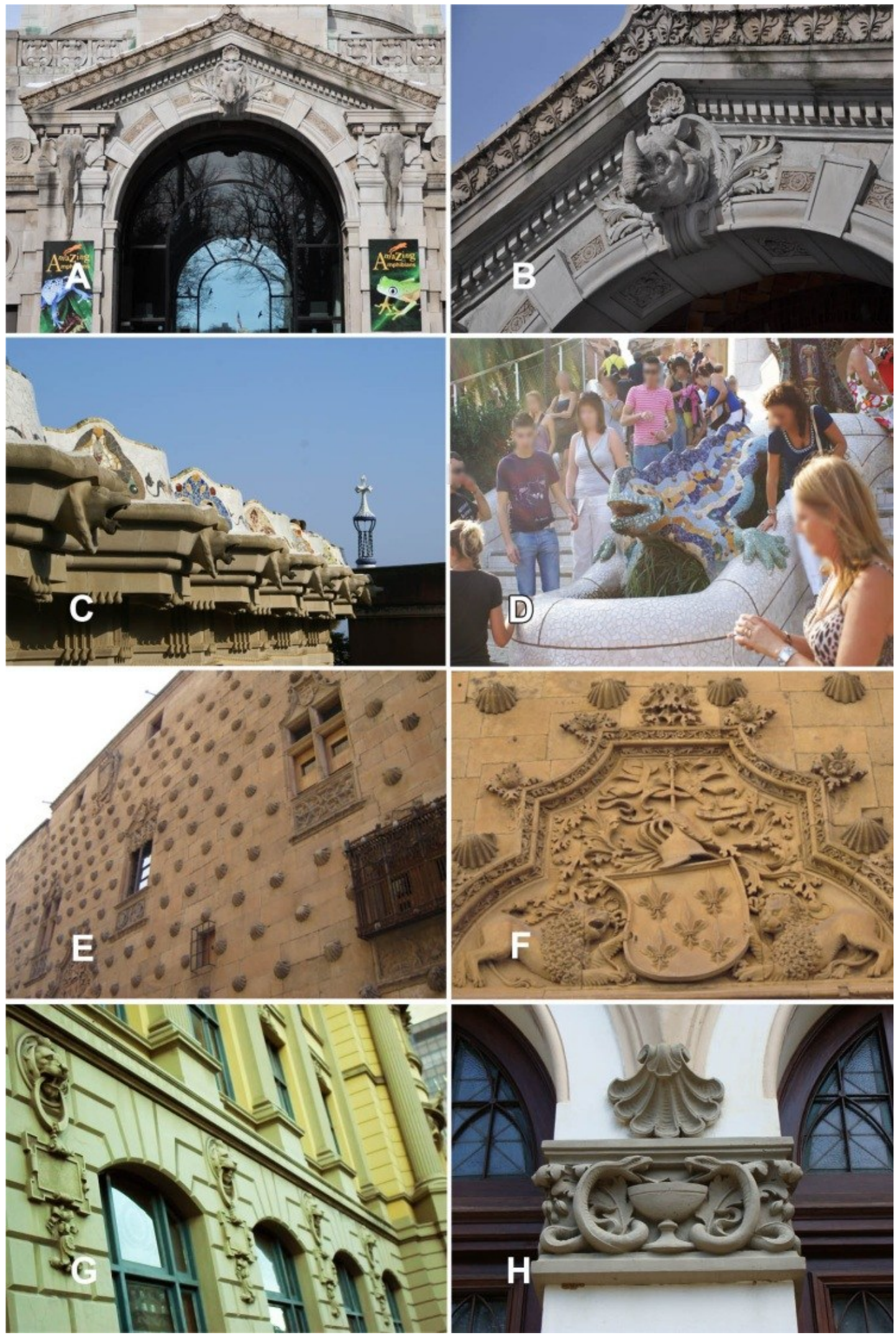

Figure 13. Animal sculptures as part of architecture of zoos and historical buildings. Animal sculptures decorating the Bronx Zoo (New York, USA) (A and B) and the Park Güell, Barcelona, Catalonia, Spain $(C$ and $D)$; Bivalve shells and lions decorating the wall of Casa de Las Conchas, Salamanca, Spain (E and F); Lion heads adorning the facade of the national library, Rio de Janeiro (G) and sculpted snakes of the Butantan Institute, São Paulo, Brazil $(\mathrm{H})$. Photo credits: A and B - Itamar Barbosa; C and D José S. Mourão; E and F- Ulysses Paulino de Albuquerque; G and H - Kleber S. Vieira. 

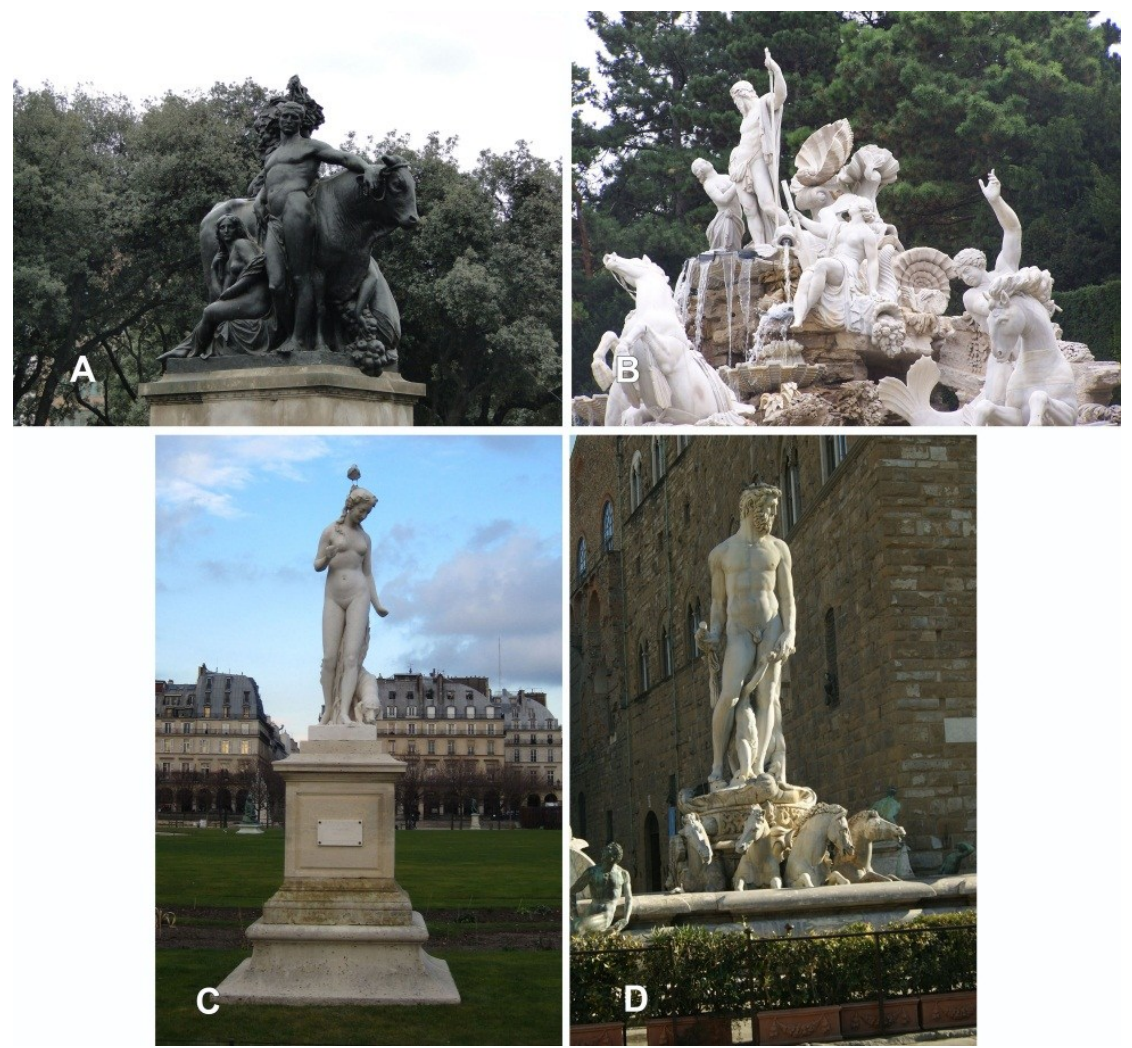

Figure 14. Representation of humans (or deities with human shape) with animals. A - Sculptures of bull (a symbol of Catalonia) together with humans, Barcelona, Spain. B - Neptune Fountain at Vienna's Schönbrunn Palace, with mythical animals, Vienna, Austria; C - Statue of woman and dog in the Tuileries Gardens, Paris, France; D- Neptune Fountain, the Roman god of the sea surrounded by water nymphs and animals in San Gimignano, Italy. Photo credits: A and C- Rômulo R. N. Alves; BMaria S. Pereira; and D - José S. Mourão.
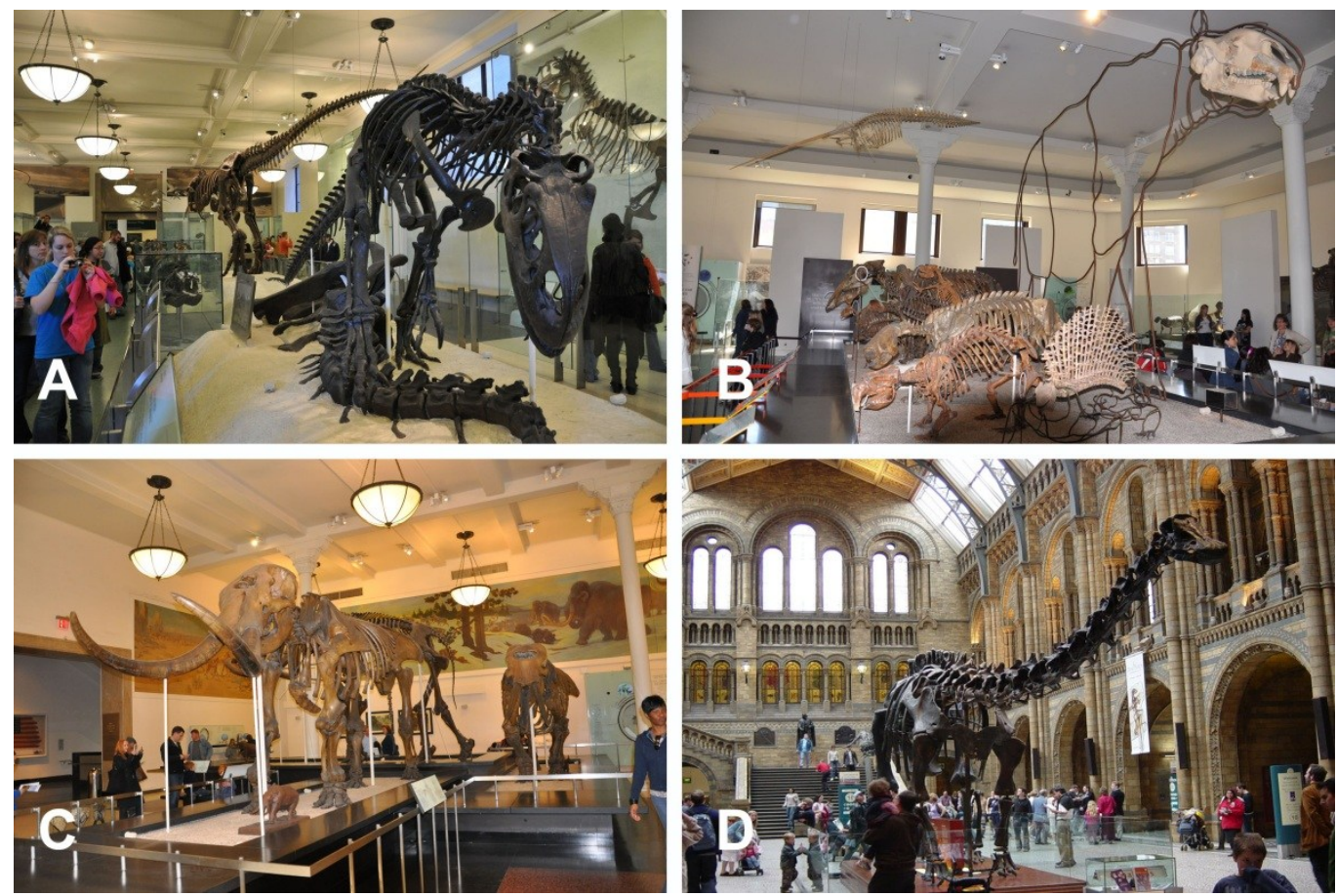

Figure 15. Skeletons of extinct animals on exhibition at the American Museum of Natural History, New York, USA (A, B and C) and Natural History Museum, London, England (D). Photo credits: Itamar Barbosa (A, B and C) and Edgley A. César (D). 
Alves 2012. Relationships between fauna and people and the role of ethnozoology in animal conservation. Ethnobio Conserv 1:2
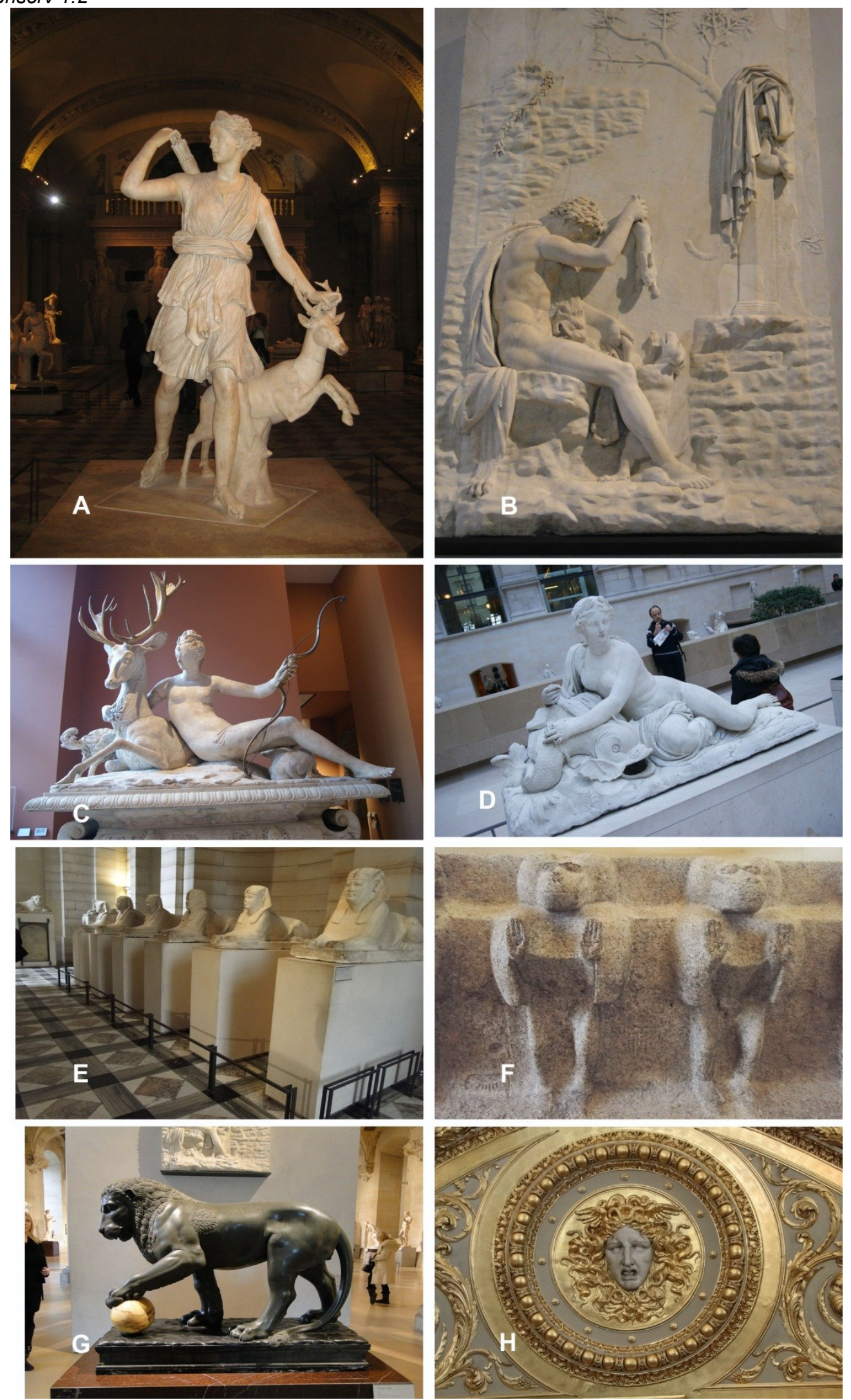

Figure 16. Anthropozoomorphical and animal representations in sculptures and statues exhibited in the Louvre Museum, Paris, France. A and C -Greek goddess Artemis (Latin: Diana), with a deer; B Sculpture of man feeding a rabbit to a dog; D - Mythical animal and Amphitrite, the wife of the Greek god of the sea, Poseidon (Roman: Neptune); E- Egyptian sphinxes; F - Baboons; G - Lion sculpture; $\mathrm{H}$ - Medusa (with snakes in place of hair). Photo credits: A, B, E, F, G and H-Rômulo R. N. Alves; C and D - José S. Mourão. 
Alves 2012. Relationships between fauna and people and the role of ethnozoology in animal conservation. Ethnobio Conserv 1:2
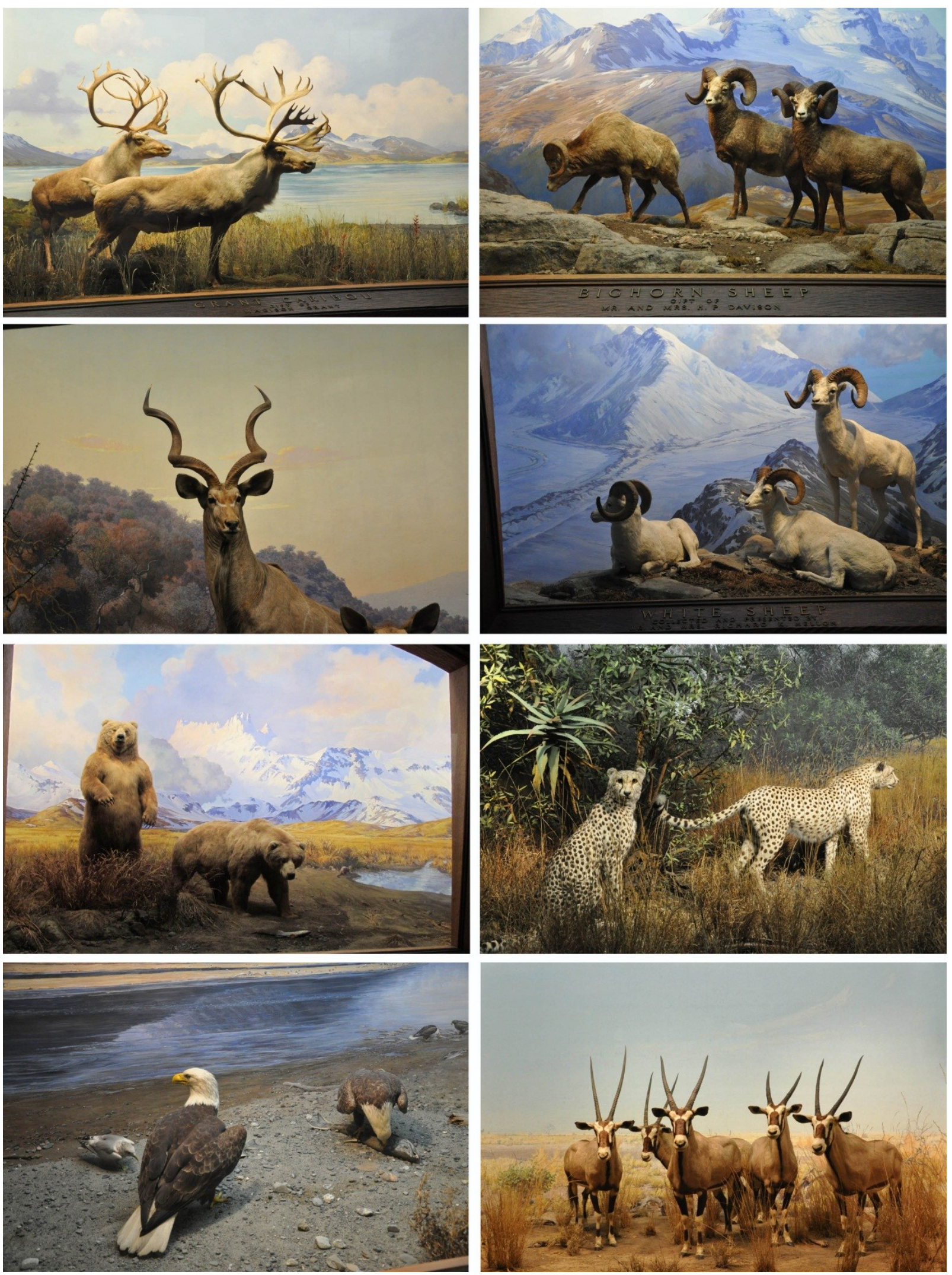

Figure 17. Dioramas of animals on exhibition at the American Museum of Natural History, New York, USA. Photo credits: Itamar Barbosa. 
The earliest musical instruments are found to derive from a common source: hunting implements. Loud instruments (percussion instruments, reeds, trumpets) were used to call or repulse prey and to signal between hunters. Some literacy sources from ancient Greece and China, as well as iconographic material from Egypt and Mexico, provide later descriptions of the music/hunt association (Lawergren 1988). Even today, some cultures provide examples of their music imitating natural sounds. In some instances, this feature is related to shamanistic beliefs or practice (Deschênes 2002; Hoppál 2006), but it may also serve as entertainment (game) or practical functions (luring animals in hunt) (Alves et al. 2009a; Bezerra et al. 2012; Deschênes 2002; Fernandes-Ferreira et al. 2012a; Kothari 2007).

Animals also hold an important place in written literature. Examples are the writings of Shakespeare, which contain over 70 abstractions appearing in animal form, and over 4,000 allusions are made to animals in his writings (Yoder 1947). The nineteenth and twentieth centuries produced such writers as Melville (speculating about a whale's feelings), Dickinson (who wrote over 300 poems featuring animals), Hemingway (who wrote about the fear experienced by a fish before it is about to be caught), Twain, and Steinbeck (Allen 1983). The animals' points of view, as depicted by these authors, served as a precursor of the anthropomorphic (the attribution of human characteristics to non-human entities) use of animals in many settings (Spears et al. 1996). Additionally, writers such as Nietzsche, Kafka, Max Ernst, D. H. Lawrence, and Darwin advanced philosophies that caused traditional boundaries between the animal world and that of human beings to appear insignificant while simultaneously expressing the idea that anthropomorphism exists to serve human psychological needs (Norris 1985).

Because of the close relationship between animals and human throughout history, animals have been used in all cultures to reflect the nature of humanity, symbolizing societal and individual human characteristics (Merrill 1990). The power of the human affinity with animals is manifest not only in direct interactions between people and animals but also through the process of using animals to symbolize many aspects of life (Lawrence 1997). The cultural importance of animals has resulted in their widespread use as symbols, icons and representations throughout history. The morals of Aesop's fables, as colourfully portrayed by animals, have continuing relevance to modern man (Spears et al. 1996). Societies have handed down morals through the continued use of animals to symbolically communicate important cultural values (Chesterton 1912). Examples of the use of animals as symbols are also found in religion. In the Bible, a donkey served to warn Balaam of God's will. The Bible also tells the story of a crafty, talking serpent who skilfully managed to deceive Adam and Eve in the Garden of Eden (Spears et al. 1996).

Animals provide multidimensional symbols that can be used to transmit cultural meanings (Morgado 1993). Robin (1977) argued that, from the earliest days of civilization, animals have been used symbolically to portray a wide range of human qualities, including the orderliness of the bees, the treachery of the hyena, the hypocrisy of the crocodile (crying "crocodile tears"), the cunning of the fox, the friendship/loyalty of the dog, the inconstancy of the chameleon and the peace of the turtle dove. As such, animal symbols are defined culturally and belong to the collective memory of members of society. They form the basis for "an inexhaustible repository which novelists, poets, artists, dramatists, film makers, and even advertisers draw on, either consciously or intuitively, when they wish to evoke an immediate yet profound response"(Rowland 1973). Even early humans saw animals as exemplifying human traits (Spears et al. 1996). 
Animals, both real and mythical, are used as national symbols in nations and monarchies (Collar et al. 2007; Sleeboom 2002). Most countries choose an animal that is closely related to the country as a national symbol. For example, the Andean Condor plays an important role in the folklore and mythology of the South American Andean regions, and is a national symbol of Argentina, Bolivia, Chile, Colombia, Ecuador and Peru (Herrmann et al. 2010; Reid 1957). The giraffe is a national symbol of Africa, and to many people the large herds of ungulates on the savannah symbolize the African environment and its history (Kaltenborn et al. 2006). In other cases, animals are chosen because they represent some coveted attribute such courage or strength. For example, the eagle of the USA is a symbol of strength and bravery (Ajala 1991) and, as a vehicle of communicating patriotism, the eagle is rivalled only by the flag, the Declaration of Independence, the Constitution, the National Anthem and the Pledge of Allegiance (Center and Walsh 1981). In some form or another, eagles are also a symbol for Armenia, Albania, Austria, Egypt, Germany, Mexico, Panama, Philippines, Poland, Romania, Russia and Serbia (Lawrence 1990). Large carnivores such as tigers and lions are also popular as national symbols (Figure 18). In England, for example, the use of the lion as a national symbol dates back to Richard I (a.k.a. Richard the Lion-heart, 1157-1199 AD), whose military exploits in the Crusades and death in battle fashioned the prototype brave, courageous English lion-heart (Hand 2002). The Royal Bengal Tiger is the national animal of both India and Bangladesh (Sexton 2011).
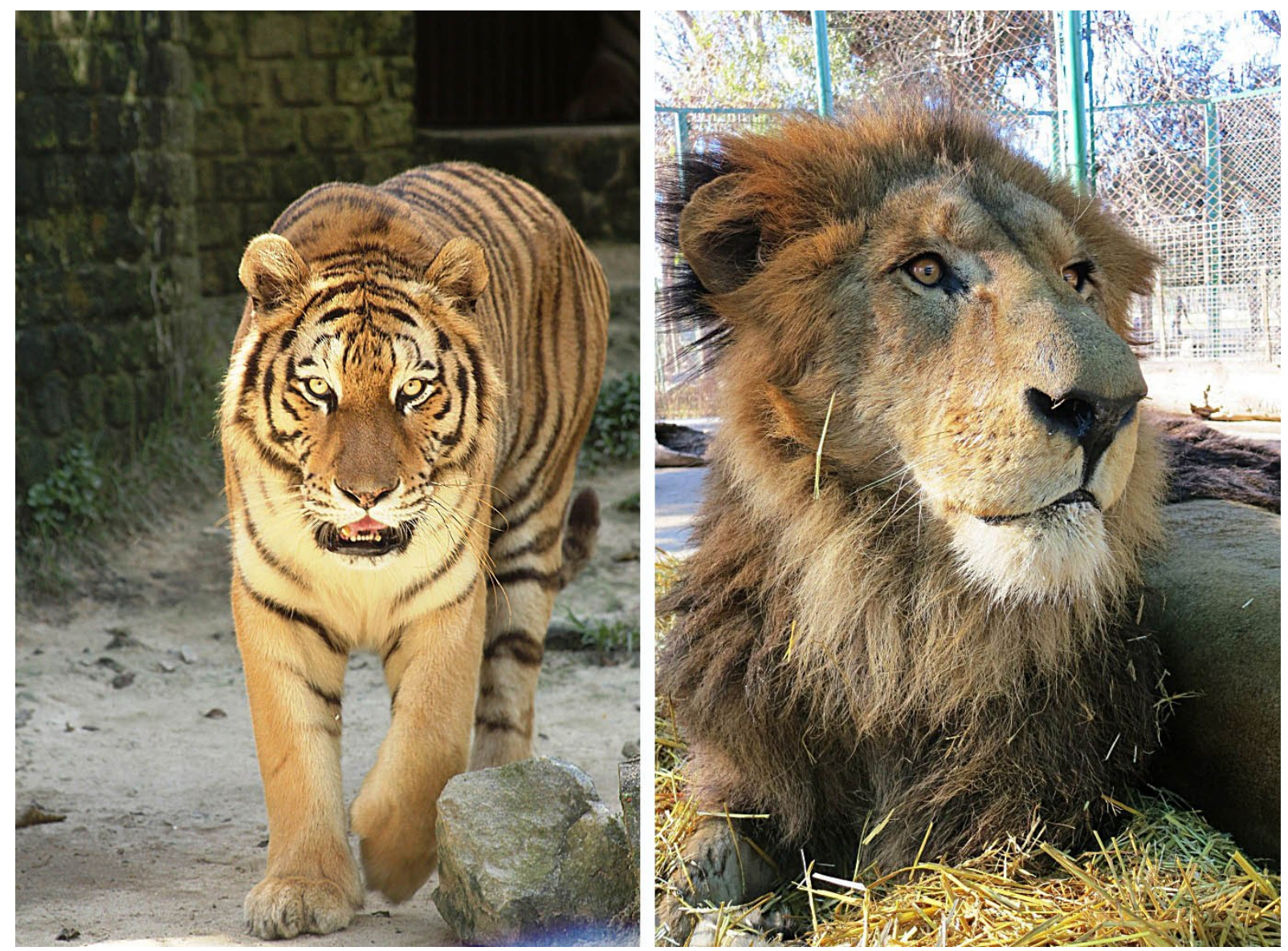

Figure 18. Big cats such as tigers (Panthera tigris) and lions (Panthera leo) have been a popular symbol of royalty, stateliness and bravery, where they are usually used as national symbols in various countries. Photo credits: Christinne C. Eloy. 
The symbolism of animals is particularly obvious in sport. The English see lions as brave, proud animals and the English football team symbol portrays three lions on the front of their football shirts. Australia is famous of course for kangaroos. The national rugby team is more commonly known as the Wallabies, a kind of small kangaroo. Similarly, the South African team is known as the Springboks, a type of African antelope, and New Zealanders, whether or not in the context of sport, are commonly known as Kiwis. A kiwi is a native New Zealand bird that cannot fly (BBC 2007). In Brazil, Straube (2010) analysing the symbology of birds in national football, recorded 51 official shields which showed one or even more bird species. The most popular team in the country (Flamengo), for example, is symbolized by a vulture.

\section{Animal as ornaments, decoration, tools and others purposes}

Since prehistoric times animal products that were readily available, such as horn, bone, ivory and antler, have been used by humans as ornaments and decorative materials (Pedersen 2004). Early humans lived alongside the animals they hunted, eating their meat, using their hide and putting their bones and tusks to use as building materials, or fashioning them into ornaments or weapons (Pedersen 2004). The contribution of animals to this aspect of human welfare is extensive and varied (Fitter 1986).

The use of animal bones for the production of various tools, artefacts and common objects, though less common than the use of stone and wood, was already well-known during the Old Stone Age (Palaeolithic) in Palestine and in many parts of the Near East, as well as in areas far removed from those locations (Oakley 1972). Objects made from bone included spear throwers, fishhooks, lance points, needlessome pierced with an eye for the stitching together of skins-and ritual ornaments. Many of the beautifully made implements, usually those that were smaller, were fashioned from bones. However, the available evidence indicates clearly that, with the exception of artefacts such as needles, which were commonly made of fish bones, they were usually produced from the bones of land animals. Similarly, the skins and hides that were the raw material for clothing and for a great many utilitarian objects were generally those of land animals until the invention of weaving. This has been demonstrated by archaeological discoveries interpreted through the labour and perception of many eminent ethnologists and historians (Neufeld 1973).

A wide variety of wildlife products have been used through time for decoration and ornamental purposes, including ivory, coral, turtle and mollusc shells, reptile and other skins, and feathers (Oldfield 2001; Pedersen 2004). Wild-animal-derived decorations and ornaments are often high-value luxury products. They may be bought for decoration, fashion, as a part of traditional wear or for luck and prestige. Some ornaments form an integral part of a local tradition-for example, combs made from bekko (tortoiseshell) are part of the traditional Japanese wedding outfit-but others are merely a response to the demands of fashion (Bagniewska and MacDonald 2010).

Birds are among the main groups to have been explored as a source of products for use as trappings or decoration (Collar et al. 2007; Kothari 2007). Initially, feathers were regarded as a status symbol. They were very much part of any tribal attire in all parts of the world. In Africa feathered headdresses or necklaces were worn by shamans or "witch doctors", possibly together with animal teeth and bird beaks. In South America, whole capes were covered in bright feathers, for example, 
the scarlet feathers of the ibis. Native Americans wore them as headdresses or jewellery and, in some cases, accorded them talismanic powers. Even in Scotland, the number of eagle feathers worn on the bonnet signified rank and, although it is an old custom, the rule still applies. Only the clan chief may wear three eagle feathers, and a chieftain may wear two (Pedersen 2004)

Throughout the world, people use bird plumes to decorate themselves, particularly to create headdresses. Styles vary enormously, as do the reasons for creating headdresses and for preferring certain bird feathers above others (Biebuyck and Van den Abbeele 1984). The plumes used and the manner in which they are worn may, for instance, mark the wearer's achievements, as in the coup complex of the Plains Indians. Alternatively, they may indicate initiatory status and knowledge as in, for example, the Baktaman of New Guinea. In other societies they may indicate social standing and wealth, and may even be worn to enhance the beauty of the rich, as in Edwardian England when the demands of "society belles" for bird of paradise plumes brought some of these majestic creatures to the verge of extinction in parts of Melanesia. Elsewhere, plumed headdresses may serve as regimental insignia to distinguish warriors clearly in battle as, for example, among the Zulu peoples in the last century. They may also be intended to confuse the enemy as to their opponents' numbers, such as the ostrich feather rings of the Masai. Other societies have included the plumes of certain birds in their headwear in the belief that this will effect some sympathetic transfer of the birds' qualities to them; for instance, that an owl's plumes might improve their night vision (Sillitoe 1988). Today, feathers are again popular in jewellery, most commonly hanging in pendant earrings or necklaces. They are often dyed, as most birds having naturally exotic, coloured plumage are protected by conservation treaties, although this does not always prevent their use. The feathers used come mostly from domestic fowl such as ducks, or from game birds (Pedersen 2004).

Marine animals also provide a series of products that are used and traded as curiosities, souvenirs, crafts, jewellery (Dias et al. 2011; Grey et al. 2005; Wood and Wells 1995) or as decorative, utilitarian or non-utilitarian artefacts, and even as contemplative items. Generally, these curiosities and souvenirs are manufactured using intact dead marine animals or their parts (Grey et al. 2005). Worldwide, the marine curio and souvenir market encompasses about 5,000 species of molluscs (bivalves and gastropods), 40 species of corals, and unknown numbers of sponges and echinoderms (Wood and Wells 1988). In the last two decades, efforts to document and quantify the marine species used in this trade have been made in several parts of the world, especially for the most widely used species of fish (Gössling et al. 2004; Grey et al. 2005; Vincent 1996), sea turtles (Tröeng and Drews 2004), molluscs (Dias et al. 2011; Gössling et al. 2004; Salamanca and Pajaro 1996; Wells 1981; Wood and Wells 1995; Wood and Wells 1988), corals (USCRTF 2000), and echinoderms (Lunn et al. 2008) most widely used.

Mollusc shells comprise the majority of marine curio trade items in terms of the number of species involved and the volume commercialized (Figure 19) (Wood and Wells 1988): in the Philippines alone approximately 1,000 species of molluscs are traded and sold (Wood and Wells 1995). Shell collecting was an extremely popular hobby in the nineteenth century. The ornamental/curio/souvenir shell trade has intensified in recent years with the rise of internet shopping (Gössling et al. 2004), and the development of tourism (especially in tropical countries) has increased the market for souvenirs, with a consequent pressure on marine resources. In Brazil, for example, a total of 126 species ( 41 bivalves and 85 gastropods) were found being 
sold individually as decorative pieces or incorporated into utilitarian objects (Dias et al. 2011). Marine fishes have been also exploited as marine curios, in particular groups such as sharks and seahorses (Grey et al. 2005; Rosa et al. 2011; Vincent 1996). Each year, several hundred thousand seahorses are captured for souvenirs. Dried seahorses are popular curios in Asia, Latin America and parts of Europe, and are fashioned into earrings, brooches and keychains (Rosa et al. 2011; Vincent et al. 2011).

Different mammal products (e.g. horn, leather and teeth) are also used as trappings and decoration (Pedersen 2004). Ivory was probably the earliest organic material used for human ornamentation (Kunz 1916). Sculptures made of ivory are known to science from more than 30,000 years ago (Conard 2003). Ivory is most commonly thought of as derived from elephants, but teeth or tusks from walruses, hippopotamuses, marine whales and dolphins, and members of the swine family such as wild boar and warthogs, have also been used (Pedersen 2004). For centuries people have viewed elephant ivory as a valuable commodity, used for carvings, jewellery, and other artefacts (Naylor 2005). The Trojans wore buckles and pins fashioned from elephant tusks, and adorned their war chariots with pieces of ivory. Two thousand years ago, the Romans honoured illustrious men with handsomely chiselled writing tablets and sceptres carved from ivory. From prehistoric times to the present day, ivory has been sought as a luxury item with multiple applications. Thus, the killing of elephants to satisfy the demand for ivory has presumably been the major factor in reducing elephant populations throughout most of history (Kingdon and Pagel 1997). Skins, furs, feathers and fibres from many mammal, reptile, bird and fish species are traded internationally to make clothing, boots and shoes, bags and other items (Oldfield 2001).

\section{Animal domestication}

As early humans developed into a socially and intellectually unique species, they intensified their dominion over other species, at the same time distancing themselves from others through the development of socially elaborate cultures (Kisling 2001a). These developments accelerated during the Neolithic period (8000$3000 \mathrm{BC}$ ) as environmental conditions emerged that were favourable for the settlement of new kinds of organized, and relatively permanent, communities. This in turn provided the impetus for animal domestication (Sulman 1982; Thomas 1956).

Humans have been domesticating animals for thousands of years, marking one of the great milestones in the development of civilization (Beck and Katcher 1996) in the first efforts to keep wild animals. Although it is now taken for granted, domestication was a long-term biological process; as such, domestication required the keeping of wild animals through many generations and was achieved only after significant changes were made in the behavioural, physical, and genetic attributes of the captive species. These necessary changes could not have been anticipated in advance, and so domestication was not pre-determined (Kisling 2001a)

Archaeological evidence suggests that distinctly domesticated animals began to emerge approximately 12,000 years ago. However, many of the animals on which humans most depend were domesticated between approximately 9,000 and 6,000 years before the present time in a region known as the Fertile Crescent, in southwest Asia (Reitz and Wing 2001). The domestication of animals allowed early human societies to enrich their diets with regular sources of meat, milk and skins (Alves and 
Souto 2010). Later, certain domesticated animals provided new sources of muscular energy as pack and mounted animals, or for the traction of ploughs and wagons (see next topic), thus multiplying man's productive capacity and spatial mobility (Ribeiro 1998).
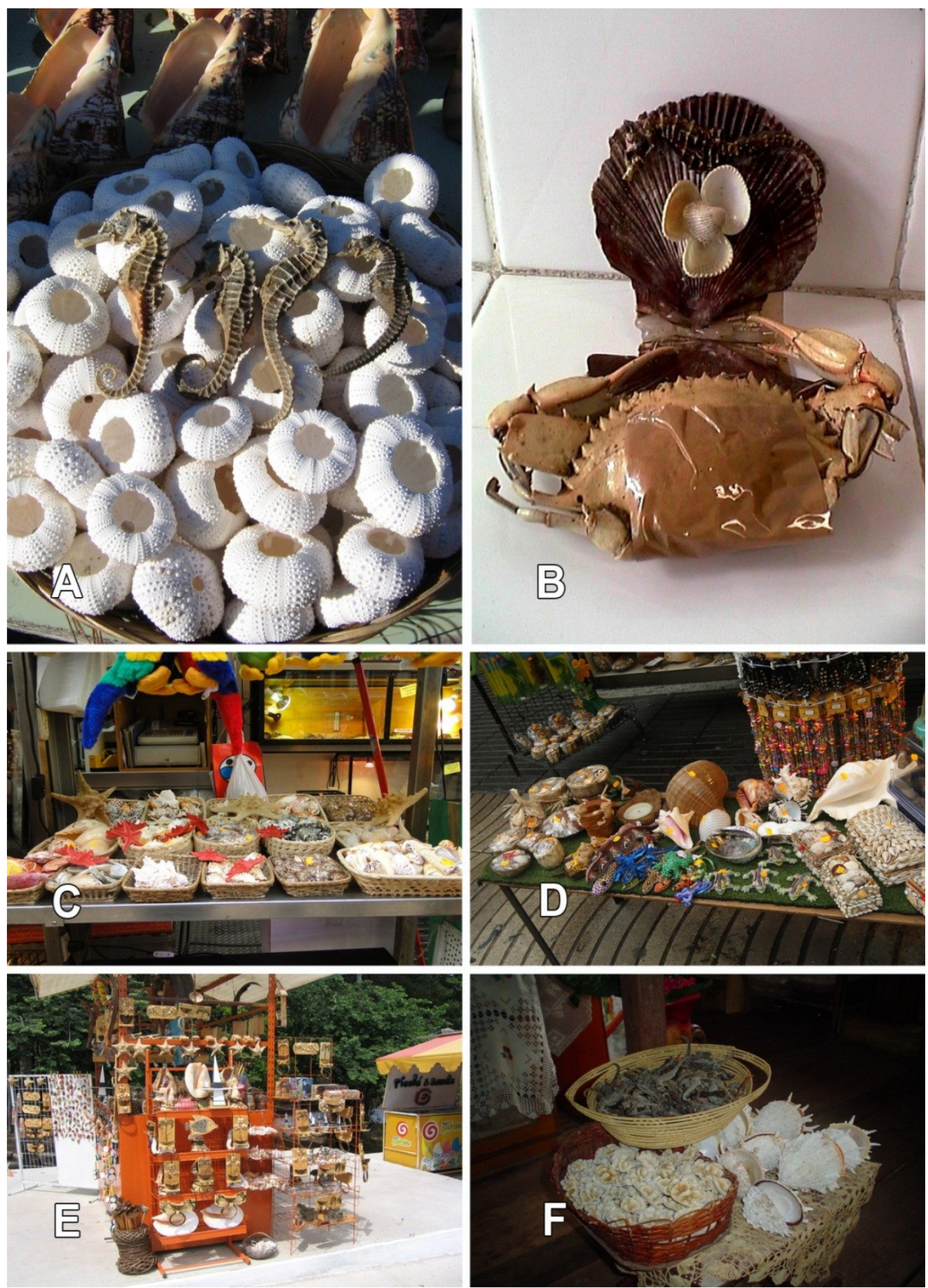

Figure 19. Some examples of animal products used as decorative objects. A - Sea urchin, mollusc shells and dried seahorse; B - Decorative items made of crab exoskeleton, mollusc shells and dried seahorse. Mollusc shells for sale in Las Ramblas, Barcelona, Spain (C and D) and at a temporary stall on Coqueirinho Beach, municipality of Conde, Paraíba State, NE Brazil (E); Mollusc shells, corals and dried seahorse for sale in municipality of Raposa, Maranhao State, NE Brazil $(F)$. Photo credits: A and B - lerecê Lucena Rosa; C and D - Tacyana P. R.Oliveira; E- Thelma L. P. Dias; and F - Rômulo R. N. Alves. 
The first domesticated animal was probably the wolf (Canis lupus) in the Middle Eastern region about 12,000 years ago, giving rise to dogs (Canis lupus familiaris-a subspecies of the wolf), which greatly aided human hunting activities (Allaby 2010; Alves et al. 2009a; Koster 2008). Cows, sheep, goats and pigs all furnished humans with meat and milk, while birds, in addition to their meat, provided eggs. Sheep and goats were domesticated in the Middle East between 7,000 and 9,000 years ago. Cattle were domesticated about 8,000 years ago in (modern-day) Iraq and, independently, about 7,000 years ago in Pakistan. Pigs were domesticated in the Orient about 9,000 years ago, and horses in southern Russia about 5,000 years ago (Allaby 2010). It is thought that geese were the first farm birds to be domesticated, although it is possible that ducks were domesticated at approximately the same time, as both birds were common in ancient Egypt. The Romans were familiar with Angolan chickens, and the original inhabitants of North America kept domesticated turkeys and may also have domesticated rabbits as a source of food. Animals that serve human needs as beasts of burden were likewise first domesticated in ancient times (although more recently than animals that produced meat and milk). Donkeys and camels were probably the first beasts of burden, with horses being acquired somewhat later. Mules have similarly been bred for thousands of years. Elephants have been associated with humans for hundreds of years, although they cannot be considered fully domestic animals as they rarely reproduce in captivity. Llamas have been beasts of burden since remote times in the Andean region of South America (Barsa 1969).

Currently, domestic animals remain critical to human development, providing nutrition, income, transportation, locomotive power, companionship and entertainment (Scanes 2003). Domestic animal diversity is an important part of world food resources. Foods derived from farm animals (meats, milk and eggs) contribute significantly to dietary intake of energy and nutrients and to the taste and enjoyment of meals (Givens et al. 2004; Hulshof et al. 1999). The livestock sector is also a dynamic part of the agricultural economy, supporting the livelihoods of many families, in particular the poorest households in developing countries (Delgado 1999; FAO 2009b)

\section{Animal traction and transport}

Several species of animals have been used for traction, as a source of power and for transport (Bowman 1977; Fitter 1986). The first evidence of traction ploughs dates back to around $3000 \mathrm{BC}$, although it is likely that similar ploughs were in use before this date. Sumerian pictograms and cylinder seals dating from the end of the fourth millennium BC first record the use of cattle power. Palaeopathological analysis of cattle bones has also suggested stress-induced conditions that might have been associated with the use of animals for traction (Sherratt 1981, 1983). The archaeological evidence suggests that cattle were probably the first species to be used for this purpose and that the earliest forms of harness for traction and power were developed using cattle, and subsequently transferred to and modified for other species. The horse is considered to be the animal on which specific riding techniques were first developed, though cattle and other animals had previously been used for carrying people. From about $3000 \mathrm{BC}$ onwards there is increasing evidence that, apart from cattle and horses, reindeer, onagers (wild asses), asses, Bactrian camels, 
dromedaries, buffaloes, yaks, and elephants were used for traction and transport (Bowman 1977).

Animals utilized throughout the world as a source of traction include horses, mules, asses, buffalo, cattle, camels, yaks, llamas, alpacas, reindeer, elephants, elk, moose, sheep, goats and dogs (Figure 20) (Goe and McDowell 1980). Today, draught animals and humans provide an estimated $80 \%$ of the power input to farms in developing countries (Pearson 2005). Across the whole planet there are approximately three hundred million animals which are specifically used as traction animals for vehicles and various items of agricultural equipment in urban areas (Jordão et al. 2011). Activities included pulling implements for cultivation and harvesting, including sledges and subsequently wheeled vehicles for both peaceful and military purposes, carrying packs, bricks and other construction materials, riding, tillage, weeding, water-carrying, rubbish collection, tourism and for ceremonial purposes such as weddings and festivals (Figure 20), and for driving machinery such as threshing, milking and irrigation equipment (Bowman 1977; Pritchard et al. 2005).

Though the development of motors driven by energy derived from fossil and nuclear fuels, wind, water and others sources, has considerably reduced the need for animal power and transport, there are many parts of the world where motor power is still inappropriate. For example, therefore, in mountainous terrain, in paddy fields, and in areas without roads or which are short of fossil and other fuels, the use of animals for traction and transport is dominant and is likely to remain so (Bowman 1977). Despite increased mechanization, three billion people living in 30 developing countries still depend on the traction power of animals for agricultural production and the transport of goods and people (Ramaswamy 1998).

Animal traction is in many parts of the world an affordable, appropriate and sustainable technology (Starkey et al. 1994). Although it is most commonly used in developing countries, many developed countries are seeing a resurgence of interest in the use of draught animal power (Bradbury 2002). In continental Europe, for example, farmers are increasingly viewing horsepower systems utilizing the latest horse-drawn equipment as a modern, ecologically and economically sound alternative for use in organic operations (Herold et al. 2009). In many parts of the developing world, including Asia, North Africa, Ethiopia, and the Americas, animal traction has provided an essential source of power for hundreds if not thousands of years (Starkey et al.1994).

Animal traction plays a vital role in both urban and rural transport (Bradbury 2002). In Eastern and Southern Africa it plays an important role in rural economies and helps to relieve the transport burdens of rural households (Denis 1999). In Brazil, especially in the northeastern region, traction animals are widely used, mainly on small rural properties, in several activities related to rural life. These activities range from soil preparation to harvesting, planting and transport of produce. Animals are also used to carry water, wood, for dragging logs and to transport people. In Africa, animals provide a more affordable and efficient way of moving goods over short distances and offer an efficient alternative to human transportation methods such as head loading (Anderson and Denis 1994). Both rural and urban businesses and entrepreneurs in South Africa utilize animal drawn carts for the transport of goods, with the profitability of animal power often exceeding motorized transport, depending on factors such as distance travelled and loading times (Starkey 1995). Animal transport also offers advantages in its ability to operate using low quality tracks and paths, and it does not require imported fuel. Arriaga and Jordan (1999) list the income-generating transport activities of the equids owned by poor small farmers in 
Mexico, supplementary to their role in agricultural cultivation. These activities include rental of the equid for transport purposes, transporting the harvest, distributing manure and fertilizers to fields, and other transport activities such as carrying building materials, and domestic chores including carrying of water and fuel wood, which would otherwise have to be transported manually.

It is important to remember that, in addition to furnishing a source of power, these same animals provide milk, fuel, wool, hair, off-spring, and by-products, such as hides, horns, hooves and meat at the end of their working lives (Goe and McDowell 1980). Although some authors point out that the relationship between domestic animals and humans has been mutualistic, with humans using animals as a workforce and using several animal products, but in turn providing shelter, food, general care and protection against predators (Heffner 1999; Jordão et al. 2011), there is an increasingly debated concern about the welfare of haulage animals. In the last few years several examples of abuse of haulage animals have been recorded, including stress and excessive tension caused by intense overload, injuries and the use of sharp instruments such as prickles and whipping to force animals to work beyond their capabilities. They are also deprived of food for a long time (and given bad quality food), including water and appropriate rest, as well as being deprived of behavioural freedom (Jordão et al. 2011). In some cases, animals that are sick or in advanced pregnancy are nonetheless forced to work (Ramaswamy 1998).

\section{Menageries, zoos and aquariums}

People have always upheld a certain fascination for wildlife. As previously discussed, animals have always inspired admiration and fear. Domestication allows the existence of close contact with several animal species that have been kept as pets until the present day. In order to contemplate dangerous, wild and exotic species, it was necessary to keep them in private collections, a practice recorded since ancient times and which has been perpetuated throughout history and has evolved into zoos and aquariums, institutions currently spread across the globe.

Well before the establishment of the places we call zoos, humans kept animals in captivity for diverse purposes, chiefly as creatures of worship (Zuckerman 1979). The first captive animals were almost certainly domesticated species kept for food-sheep, cattle, goats-and those kept for companionship, such as dogs and cats. Others were kept for religious reasons, as symbols of wealth and because powerful animals conferred superior status on their owners. Some species were believed to be incarnations of either gods or dead ancestors, and others were used as sacrifices. Some South American Indians kept certain bird species as currency (Morris 2011). By the third century BC, Romans had introduced violent uses of animals into their gladiatorial contests and triumphal processions (Zuckerman 1979). Gladiators fought each other or fought against wild animals that were kept in cages beneath the stadium (Hopkins and Beard 2011). A contest with a wild, half-starved animal was also a method of public execution. The games held in the Coliseum were hugely popular. The opening spectacle of the Coliseum games lasted for 100 days, and by its end more than 9,000 animals and 10,000 condemned prisoners had been killed (Allaby 2010). The Roman public had an insatiable appetite for such events, but well-to-do citizens also kept pets and small menageries. Dogs were popular, as were ponds stocked with colourful fish, aviaries and caged animals such as gazelles. 
Some people even kept pet lions, usually with their claws and teeth removed (Allaby 2010).

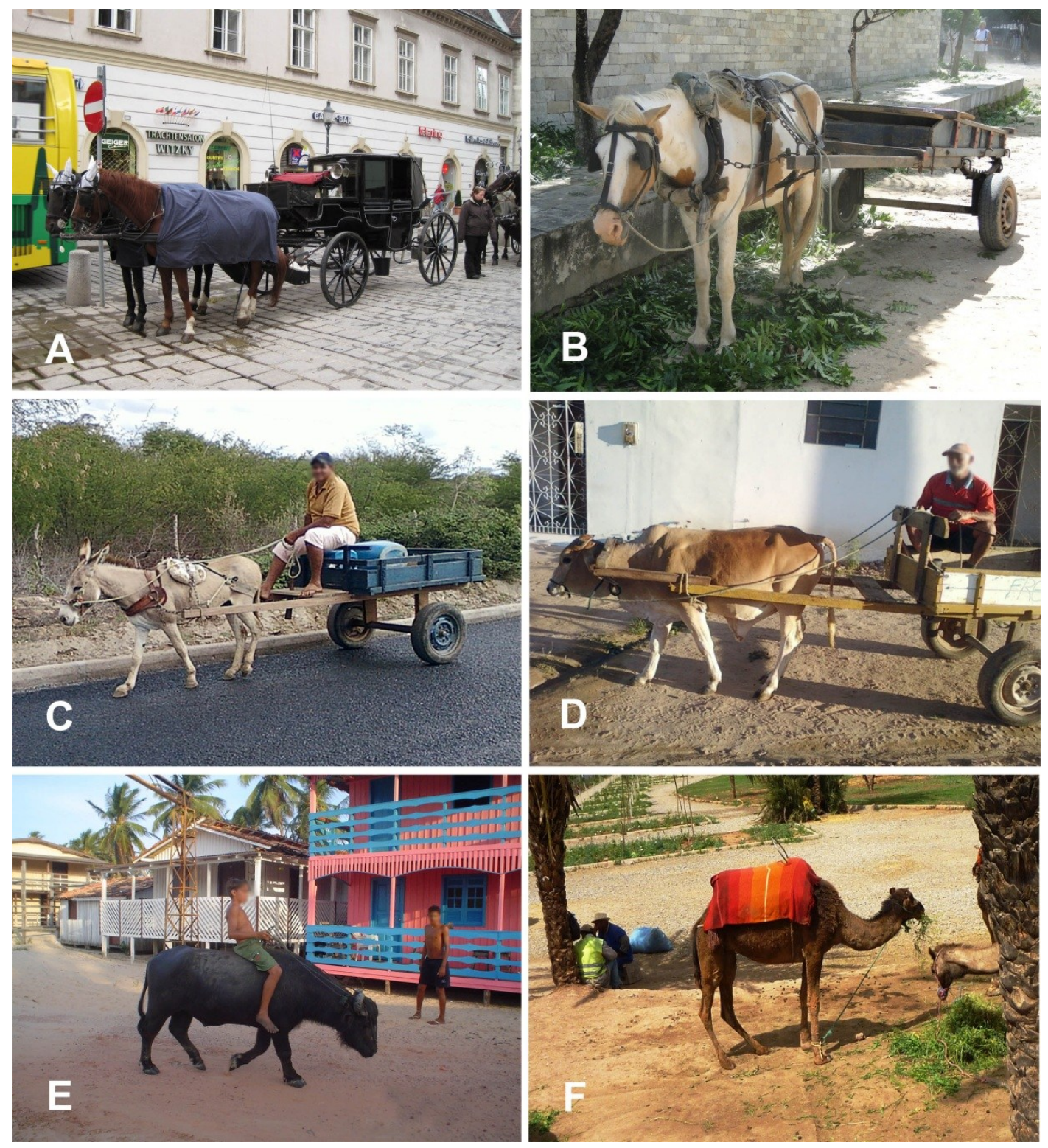

Figure 20. Examples of animals used for traction and transport. A - Horse-drawn carriage in Vienna, Austria; Horses (B), donkey (C) and bull (D) used for pulling carts with loads in the cities of Paraíba State, NE Brazil; D - A child mounted on a buffalo on Marajo Island, North Brazil, where they are used for transport and traction, and E - Dromedary in Marrakech, Morocco, used for transport. Photo credits: A - Tacyana P. R. Oliveira; B and E - Rômulo R. N. Alves; C and D - Márcia S. Z. Sousa; and F - lerecê Lucena Rosa.

The keeping of wild animals by humans has a very long history (Morris 2011). From the very earliest times rulers and wealthy aristocrats have assembled collections of wild or exotic animals and maintained them in parks or gardens adjacent to their palaces. The animals were not kept in captivity so that natural historians might study them, but for entertainment, and the animals themselves were usually chosen because, although exotic, they were not so violent as to be difficult or dangerous to manage (Allaby 2010). These private collections, or "menageries", of animals were maintained for entertainment or to impress visitors, and became status 
symbols for their princely owners (Allaby 2010; Anderson 1995). One such collection was the Versailles menagerie opened in 1665, when Louis XIV arranged a botanical garden and an enclosure for lions and elephants around his house in a pattern that is said to have inspired Bentham's Panoptican prison of the late eighteenth century (Mullan and Marvin 1998). In 1804, in keeping with the democratic order of postrevolutionary France, the royal animals were moved to Paris and a zoological garden at Jardin des Plantes was opened to the public (Anderson 1995).

In the Middle Ages, most European monarchs and many nobles owned menageries. In the eighteenth century, travelling collections of animals were popular in Europe and in America as a form of popular entertainment, and were also known as menageries. In 1716, in Boston, a lion became the first wild animal to be exhibited in America. Other animals quickly followed. In America these exhibitions were combined with circus shows based on clowns, acrobats, and other human as well as animal performers. A single ticket allowed entrance to both the circus and the menagerie, and the menagerie was as popular and important as the circus (Allaby 2010).

The modern zoo has its origins in the royal menageries of ages past, where animals were kept for the purposes of exhibition and entertainment for the privileged few (Bennett 1829). The earliest important Western European menageries after the Middle Ages began in the Italian, Portuguese, and Spanish courts. The most important transitions to the modern zoo took place in Vienna, Berlin and Paris. The oldest existing zoo, the Vienna Zoo in Austria, evolved from the Imperial Menagerie at the Schönbrunn Palace in Vienna, an aristocratic menagerie founded by the Habsburg monarchy (Strehlow 2000). The zoo was constructed by Adrian van Stekhoven in 1752 next to Schloss Schönbrunn at the order of the Holy Roman Emperor Francis I, husband of Maria Theresia, to serve as an imperial menagerie (Morris 2011; Strehlow 2000). It was centred around a pavilion intended for use for imperial breakfasts (Figure 21). The central pavilion and the menagerie building were built by Jean Nicolas Jadot de Ville-Issey (Baratay and Hardouin-Fugier 2004). A small zoo had already existed on the premises since 1540, but the complex was only opened to the public in 1779 (Kunze 2000).

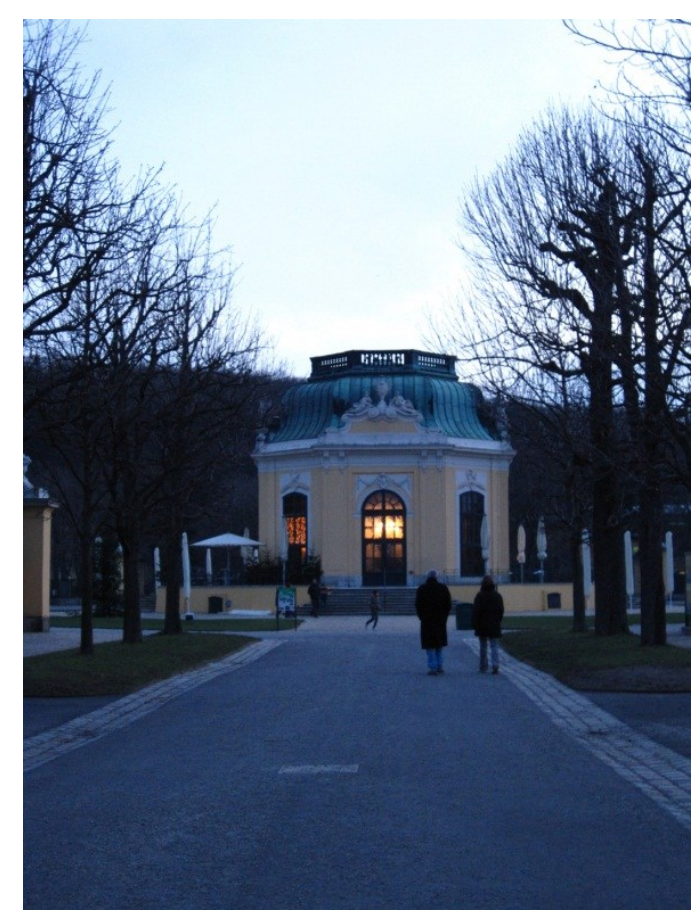

Figure 21. Octagonal Central pavilion of the Schönbrunn Zoo, Vienna, Austria, where the Imperial family used to go there to watch wild animals. Even today, this pavilion remains the zoo's historical centerpiece. Photo credits: Tacyana P. R.Oliveira. 
The admiration and fascination for wild animals are not restricted to those terrestrial species that are often kept in the menageries and zoos. In spite of the greater difficulties inherent in maintaining aquatic animals, especially larger ones, human interest in keeping them in captivity is also old. As pointed out by Clary and Wandersee (2005), editions of Punch magazine in the 1850 s and early 1860 s reveal several illustrations attesting to the popularity of aquaria in the home. Home aquaria led to public aquaria and, in 1853, the first public aquarium was opened in Regent's Park, London. Public aquaria soon followed in other English locations, as well as in Germany, France, and the United States. The aquarium concept, using selfcontained and self-sustaining systems, originated in England during the 1850s. Prior to this development, there were ornamental fish ponds, these being open systems supplied with water from nearby seas, lakes, or streams (Kisling 2001a).

Nowadays, zoos and aquariums are spread across the world in different cities (Figures 22 and 23) (Kisling 2001b; Yearbook 2012). More than 700 million people visit over 1300 zoos and aquariums globally each year (http:// www.waza.org/en/site/zoos-aquariums). Zoos and aquariums continue to evolve. Their role as cultural institutions is changing in many ways. At the same time they remain true to their traditional commitments concerning recreation, education, research and conservation (Kisling 2001a).
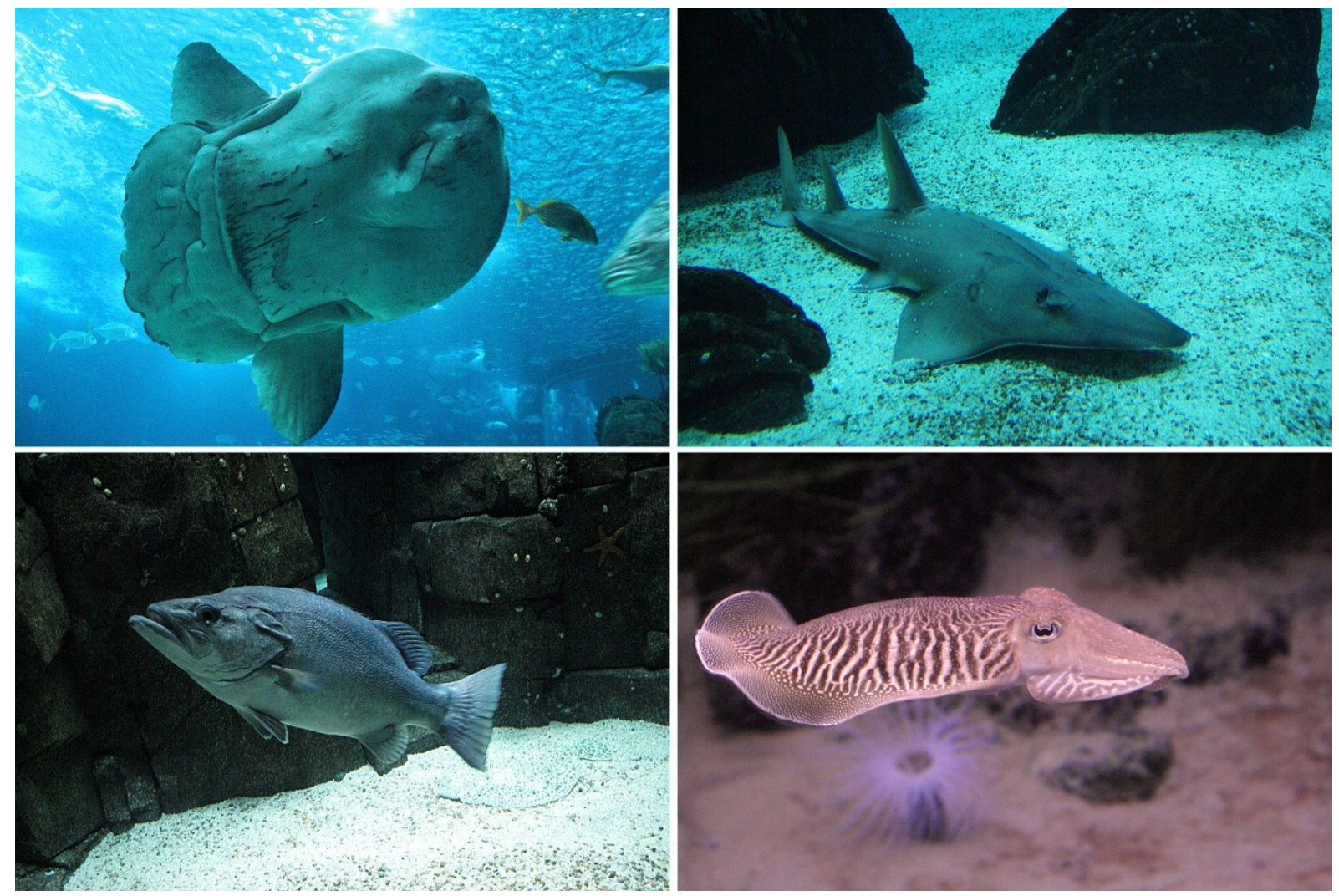

Figure 22. Some fishes and mollusc of the L'Aquàrium de Barcelona, Spain. Photo credits: José S. Mourão. 
Alves 2012. Relationships between fauna and people and the role of ethnozoology in animal conservation. Ethnobio Conserv 1:2
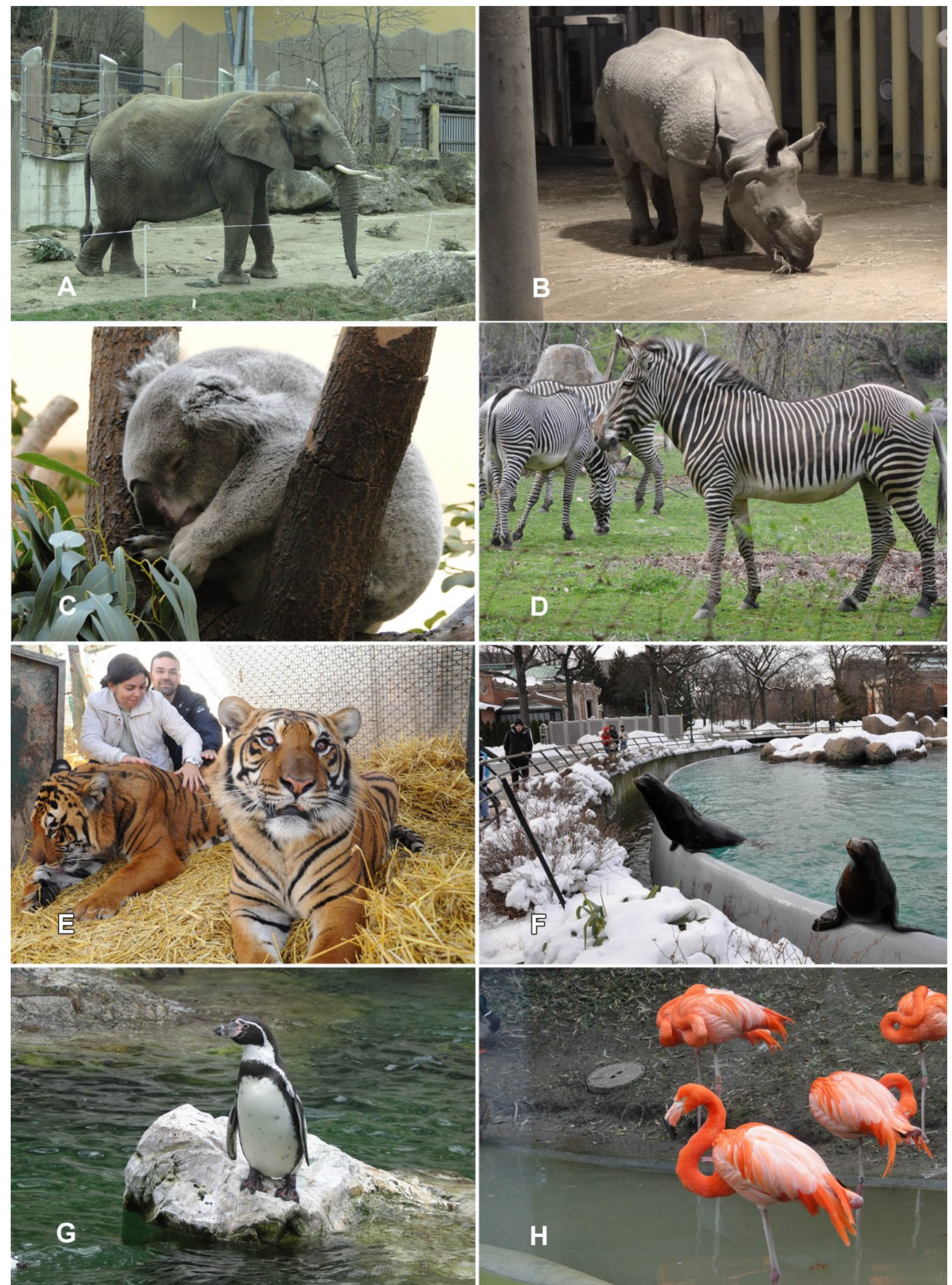

Figure 23. Some examples of animals kept in zoos. A, B,C,G and $H$ - Zoo Schönbrunn, Vienna, Austria (Photo credits: Rômulo R. N. Alves); E - Lujan Zoo, Buenos Aires, Argentina (Photo credits: Christinne C. Eloy); D and F - Bronx Zoo, New York, USA (Photo credits: Itamar Barbosa) 


\section{Ethnozoology and conservation}

Human beings simply represent one of the many species that constitute the biodiversity of the planet, linked through a series of relationships. This way, similar to any other organism, the human species influences the environment where it lives. However, as a results of both genetic and cultural evolution humans have become the dominant species on earth today (Ehrlich and Ehrlich 2008), a condition that has strengthened their influence on biodiversity. Ehrlich and Ehrlich (2008) highlight that "Homo sapiens has become so powerful that it can significantly undermine the ability of Earth's environment to support much of life - including our own". As the human population has grown and the power of technology has expanded, the scope and nature of this modification has changed drastically. Until recently, the term "humandominated ecosystems" would have elicited images of agricultural fields, pastures, or urban landscapes; now it applies with greater or lesser force to all of the Earth. Many ecosystems are dominated directly by humanity, and no ecosystem on the Earth's surface is free of pervasive human influence (Vitousek et al. 1997). Our actions have put humanity into a deep environmental crisis. We have destroyed, degraded, and polluted Earth's natural habitats-indeed, virtually all habitats have felt the influence of humans as the dominant species. As a result, the vast majority of populations and species of plants and animals-key working parts of human life support systemsare in decline, and many are already extinct (Sodhi and Ehrlich 2010).

Obviously, the influence of anthropic activities over other animals varies according to its intensity through history and depends on the human cultures with which animals interact. The effects of human actions over animal populations have not always had the impact expected. The exploitation of fauna, hunting and primitive fishing techniques, which are still perpetuated in some traditional communities, results in a lower pressure on the exploited animals population and in most cases allows sustainable use of fauna resources.

In the last few decades, however, human populations have grown, and the ways in which biodiversity is exploited are changing to meet the demands generated by this population growth. According to the FAO (2009a), the human population is set to reach nine billion by 2050 , meaning a greater demand for food, water and energy. As a consequence, pressures on wild species and natural ecosystems are becoming increasingly severe, resulting in an increase in hunting, fishing and other exploitation of the faunal resources. Unfortunately, because of overexploitation by humans, combined with loss of suitable habitat, conflicts with people, invasions by exotic species and disease and other causes, many species of animals are now considered to be endangered in the wild. Practically all threats which affect the animal species included in the IUCN Red List (see http://www.iucnredlist.org/) are direct or indirectly associated to anthropogenic activities.

This scenario represents a challenge in the quest for ways of exploiting animal resources but which minimize the impact on animal species, allowing its sustainable use. This challenge becomes more complicated as the human population grows, and new technologies allow a greater exploitation of aquatic and terrestrial animals to meet the demand for food. If we consider that, in some cases, human beings have lived and exploited fauna in a way which causes lower pressure on the species, while in other cases exploitation has caused serious impacts on them, it is urgent that animal conservation strategies try to reconcile human and conservation needs. It is therefore necessary to understand the multidimensional context (biological, social economic, cultural, politic and institutional factors) within which the interactions 
between humans and animals evolve. In this context, ethnozoological research is essential to conservation efforts. Such research can aid in the evaluation of the impacts human populations have on native animal species and in the development of sustainable management plans.

The global biodiversity crisis, caused mainly by anthropogenic actions, makes clear that ethnobiology can contribute considerably to conservation biology, especially considering that these disciplines show many similarities. As pointed out by Soule (1985), conservation biology was originally conceptualized as a "crisis" discipline, with the goal of providing the principles and tools for preserving biodiversity. Newing (2010) noted that like ethnobiology, conservation biology has a long history as a concept but emerged as an academic discipline in the 1980s, largely in response to the increasingly urgent need to address the perceived biodiversity crisis (Noss 1999). The mission to preserve biodiversity is clearly valuedriven and implies urgency, and yet the techniques of conservation biology are scientific. The research questions and methods are derived from a broad range of pure and applied fields (Saunders 2003). Many of the early conservation biologists were field biologists whose study sites faced an immediate threat of destruction from the impact of human activities, yet their professional training in ecology left them illequipped to deal with these threats. Conservation biology was then, from the beginning, an overtly mission-oriented discipline (Meine et al. 2006; Noss 1999). It aimed to develop new applied interdisciplinary perspectives and produce a generation of professionals who were better equipped to address the "human dimensions" of biodiversity conservation in a changing global context (Buscher and Wolmer 2007). Most of the content areas contributing to conservation biology are related to the natural sciences, but conservation biologists have acknowledged that biological knowledge alone is not sufficient to solve conservation problems (Mascia et al. 2003). In fact, Lidicker Jr et al. (1998) highlighted that "conservation needs conservation biologists for sure, but it also needs conservation sociologists, conservation political scientists, conservation chemists, conservation economists, conservation psychologists, and conservation humanitarians." I add to the list conservation ethnobiologists, who perfectly fit this scenario.

Because humans are the source of the problems as well as the hope for solutions (Saunders 2003), we cannot talk about biodiversity conservation without incorporating human dimensions. In this way, ethnobiological surveys may generate support for conservation efforts. In the case of fauna, a number of examples can be cited to illustrate the application of ethnozoology research to assisting animal conservation strategies. A good example is its potential application to solving problems of wildlife-human conflict, a widespread conservation issue of increasing concern to conservationists. Ethnozoological studies that investigate the human perception of species involved in these conflicts may provide crucial information with the aim of making their conservation efforts more effective. As pointed by Dickman (2010), social factors can play an extremely important role in human-wildlife conflict, yet are only considered relatively rarely. Animals play an important roles in the folklore of almost all cultures, and attitudes towards species can be substantially influenced by these means: for instance, mythology about vampirism is related to negative attitudes towards bats (Prokop et al. 2009), while beliefs that the aye-aye Daubentonia madagascarensis is a harbinger of doom mean it is often killed on sight, with some people believing that the entire village should be burned down and abandoned if an aye-aye is seen nearby (Glaw et al. 2008). These perceptions of certain species as innately evil or harmful mean that even if wildlife damage is 
entirely mitigated, residual fear and antagonism can lead nonetheless to continued persecution (Dickman 2010). Another example is found in research carried out by Ceríaco et al. (2011), on the subject of folklore and traditional ecological knowledge of geckos in Southern Portugal, where it is recorded that local populations hold some misconceptions of geckos as poisonous and carriers of dermatological diseases, and that the persistence of these ideas has led the population to a fear of and aversion to geckos, resulting in direct persecution, now one of the major conservation problems facing these animals. Education can help lessen hostility, but such deep-seated preconceptions tend to be hard to overcome and must be considered in conflict studies (Dickman 2010). Ceríaco (2010) points out that it is essential, from both a scientific and conservationist perspective, to understand the knowledge and perceptions that people have of these animals, since only then may hitherto unrecognized pertinent information and conservation problems be detected and resolved.

It is important to emphasize that, in some circumstances, folk beliefs, religious doctrines and species-specific taboos can be important in the conservation of declining or threatened species, and therefore such practices must be stimulated (Alves et al. 2010b). Primates exemplify this situation (Alves et al. 2010b; Shepherd et al. 2004). Some chimpanzee (Pan troglodytes) populations are not hunted because of their physical similarity to humans or because of folklore regarding an ancestral relationship with humans (Kortlandt 1986; Putra et al. 2008; Silva et al. 2005; Takeda 1998). In the village of Bossou (Republic of Guinea), the Manon people consider chimpanzees to be sacred, embodying the reincarnation of their ancestors, and believe that their ancestors' souls rest on the sacred hill of Gban. As the chimpanzee is a totem of the most influential family of Bossou, it is strictly forbidden to hunt or eat the chimpanzee (Yamakoshi 2005).

Human values and wildlife folklore strongly influence the effectiveness of conservation efforts (Alves et al. 2010b; Ceriaco 2012; Fernandes-Ferreira et al. $2012 b)$. Together with values and norms, world views underlie resource management systems and form the basis for decision-making and action (Claus et al. 2010). Failure to recognize the importance of the human dimension in animal conservation may be implied in negative consequences for management plans. The implementation of a successful management strategy fundamentally requires involvement of the main stakeholders, who must be made aware of the need to conserve natural resources as a guarantee for its sustainable exploitation.

Recent studies have shown that ethnozoology may be an important tool for use in undertaking faunal inventories and zoological and ecological research programmes (Alves and Souto 2010). This is not surprising, given that native or local populations have a profound knowledge of nature and of the biological resources they use (Alves et al. 2010d; Begossi et al. 1999; Hanazaki et al. 2009; Maass 1999; Mourão et al. 2006; Mourão and Nordi 2002, 2006; Nishida et al. 2006a,b). This has attracted attention throughout the world because traditional information and techniques have been found to complement scientific knowledge in areas such as the evaluation of environmental impacts, resource management and sustainable development (Johannes 1993; Morin-Labatut and Akatar 1992; Posey 1984; Sillitoe 1998). Individuals who retain considerable local or traditional zoological knowledge tend to be those who directly use those resources (such as hunters, fishermen, harvesters/collectors), as their success at harvesting or capturing animals is intimately linked to the quality and reliability of their ecological observations (Alves et al. 2005, 2009a; Alves and Nishida 2002; Begossi et al. 2008; Marques 1995; 
Mourão and Nordi 2003; Nordi et al. 2009; Rosa et al. 2005). As a result, these individuals retain a wide range of biological information that is able to complement traditional academic knowledge in zoology, ecology and biological conservation studies, and could be especially useful to studies of population biology, ethnology, resource evaluation and management, climate patterns and resource variations, interactions between species, relationships between abiotic factors and the fauna, ethnotaxonomy and the sustainable use and adaptative administration of natural resources (Alves and Nishida 2002; Berkes 1999; Rosa et al. 2005)

Examples show that local people can be trained as effective parataxonomists, greatly assisting in efforts to document and assess tropical biodiversity. Local collaborations also offer promising ways with which to improve natural resource management and conservation (Sheil and Lawrence 2004). Local people have already helped biologists to address goals ranging from taxonomic collection and developing estimates of local or even global species numbers (Anadón et al. 2010; Novotny et al. 2002), through to more applied concerns, such as raising conservation awareness among local communities (Basset et al. 2000) about developing national biodiversity policies (NBSAP 2000), refining timber harvesting approaches (Sheil et al. 2003), monitoring environmental impacts (Basset et al. 2001), and planning, implementing and evaluating conservation interventions (Danielsen et al. 2000; Lynam et al. 2004)

Local communities have extensive knowledge of their environments that may be used towards promoting collaborative conservation and management. Examples of such practices can be found at the Mamirauá Sustainable Development Reserve, Brazil (Castello 2004; Gillingham 2001), in Zimbabwe (Child 1996), in the Philippines (Pomeroy and Carlos 1997), and on the Pacific Islands (Michael and Lambeth 2000). Exclusion of local communities from the consultation/decision taking processes, on the other hand, may lead to the construction of public policies devoid of historical information, and without much social resonance (Alves and Rosa 2007). Ommer and Perry (2011) highlight that the management of the world's fish and fishermen remains deeply problematic, not least because, by separating fish from fishermen and by not recognizing the interdependence of these two, what are in fact interdependent problems have been treated separately.

Investigations of the regional uses of animals can also contribute to a valorization of the regional fauna from an ecological point of view as well as from economic and social standpoints, and can subsidize environmental management and species conservation plans that take into account the social and economic realities of the affected human populations (Alves and Nishida 2003; Cullen Jr et al. 2000; Rocha-Mendes et al. 2005). In many countries, especially those located in tropical regions that have great faunal diversity, the illegal commerce in wild animals removes many species from their natural environments. This is certainly one of the gravest threats to many populations of native species, and ethnozoological studies constitute an invaluable tool for understanding the socioeconomic and cultural context into which the commercialization of wild fauna is embedded-an essential aspect to the elaboration of conservation proposals. Lopes (2010) noted that ethnoecology studies have made many contributions to conservation efforts, including: initiating dialogues between local communities involved in or affected by conservation initiatives; suggesting better resource-use strategies (and management alternatives); monitoring the abundance of resources being used by human populations and the practical results of conservation management strategies; and a 
better understanding and interpretation of both general and complex ecological phenomena, environmental impacts and alterations.

\section{Final considerations}

For centuries, animals and humans have lived side by side (Boonen et al. 2012). As demonstrated in this review, close connections of dependence and codependence between humans and animals have been recorded throughout history, corroborating with Bryant (1979), who notes that the influence of animals in our lives is enormous and that our culture is richly infused with zoological components. Animals have played a wide range of roles in human life from the earliest days of recorded history, and the human species has had many kinds of interactions with others, including interactions that are predatory, competitive, parasitic, mutualistic and commensal (Baenninger 1995).

People eat animals, wear products made from them, watch them in zoos or on television, keep them in their houses and in factory farms, hunt them and experiment on them, and place them in mythology and stories (Philo and Wilbert 2000). Besides their utilitarian importance, these resources have been recognized in religion, art, music and literature and other different cultural manifestations of mankind. As expected, not all relationships between people and animals are in harmony, with antagonism being frequently the cases when animals are considered as competitors or harmful, sometimes reflecting a real situation, on other occasions reflecting diverse cultural aspects, such as folklore and religious traditions.

From an environmental perspective, the interactions between humans and animals can have negative impacts on the latter, when hunting by humans implies an additional pressure on species, or can equally have positive impacts, when cultural aspects impede their capture and killing. The degree of impact which human exploitation has on the fauna differs from continent to continent and from culture to culture. There are examples of human communities that use animal resources in a sustainable way; however, unfortunately, in the last few decades faunal exploitation through fishing and hunting has been intensified, reflecting the serious threats to the populations of exploited species. This scenario provides evidence that a more harmonious coexistence of human beings with other animals, or at least one which causes a lower impact, is an increasingly clear requirement in the context of animal conservation.

Humans influence and are affected by natural resource management issues. People are at the beginning, middle, and end of all management issues. Recognition of this central role will improve our ability to conserve nature (Jacobson and Duff 1998). In the case of faunal conservation, it is evident that an understanding of the cultural, economic, social, and traditional roles of played by animals is essential for establishing management plans directed towards sustainable use. It will be impossible to create meaningful animal conservation strategies without considering the interactions between people and animals - the focus of ethnozoological studiesmaking clear the importance of such research to animal conservation.

Ethnozoological studies also facilitate communication between researchers and the agents responsible for the elaboration of management plans and local human populations: this is of fundamental importance to the development of efficient conservation strategies (Alves and Souto 2010). The conservation of natural resources and biodiversity is indispensable not only for preserving genetic diversity 
but also for guaranteeing the subsistence of large numbers of people throughout the world.

\section{Acknowledgements}

To CNPq (Conselho Nacional de Desenvolvimento Científico e Tecnológico) for providing a research fellowship to the author. To CNPq/Edital Universal program (472623/2009-5 and 486005/2011-9) and to UEPB/PROPESQ (2008 and 2011) for financial support. My special thanks to all the researchers anf friends who allowed me to use their photos: Christinne C. Eloy, Dandara M. M. Bezerra, Edgley A. César, Hugo F. Ferreira, lerecê L. Rosa, Itamar B. Lima, Juarez C. B. Pezzuti, José A. A. Barbosa, José S. Mourão, Lívia E. T. Mendonça, Maine V. A. Confessor, Kleber S. Vieira, Márcia S. Z. Sousa, Maria S. Pereira, Priscila F. L. MacCord, Tacyana P. R. Oliveira, Tâmara P. R. Oliveira, Thelma L. P. Dias, Ulysses P. Albuquerque, Washington L.S. Vieira and Wedson M. S. Souto.

\section{References}

Adeola MO (1992) Importance of wild animals and their parts in the culture, religious festivals, and traditional medicine, of Nigeria. Environmental Conservation 19:125-134.

Ahmed A (1997) Live Bird Trade in Northern India. TRAFFIC-India.

Ajala VO (1991) The Image of Corporate Symbol. Africa Media Review 5:61-74.

Alakbarli F (2006) Medical manuscripts of Azerbaijan. Heydar Aliyev Foundation, Baku. 1 ed. 274p.

Albuquerque, Araújo E, Lima A, Souto A, Bezerra B, Freire EMX, Sampaio E, Casas FL, Moura G, Pereira G, Melo JG, Alves M, Rodal M, Schiel M, Neves RL, Alves RRN, Azevedo-Júnior S, Telino Júnior W (2012) Caatinga revisited: ecology and conservation of an important seasonal dry forest. Scientific World Journal 2012 (205182): 1-18

Alinei M (2000) A stratigraphic and structural approach to the study of magicoreligious motivations. Južnoslovenski filolog 56:75-92.

Allaby M (2010) Animals: from mythology to zoology. 1 ed. Facts On File, Inc., New York.

Allen M (1983) Animals in American literature. 1 ed. University of Illinois Press, $224 p$.

Alvard MS, Robinson JG, Redford KH, Kaplan H (1997) The Sustainability of Subsistence Hunting in the Neotropics. Conservation Biology 11:977-982.

Alves RRN, Albuquerque UP (2012a) Ethnobiology and conservation: Why do we need a new journal? Ethnobiology and Conservation 1:1-3.

Alves RRN, Albuquerque UP (2012b) Animals as a Source of Drugs: Bioprospecting and Biodiversity Conservation. In: Alves RRN, Rosa IL (eds) Animals in Traditional Folk Medicine: Implications for conservation. 1 ed. Springer-Verlag, Berlin Heidelberg, pp. 67-89.

Alves RRN, Nishida A, Hernandez M (2005) Environmental perception of gatherers of the crab 'caranguejo-uca' (Ucides cordatus, Decapoda, Brachyura) affecting their collection attitudes. Journal of Ethnobiology and Ethnomedicine 1(10): 1-8. 
Alves RRN, Alves HN (2011) The faunal drugstore: Animal-based remedies used in traditional medicines in Latin America. Journal of Ethnobiology and Ethnomedicine 7 (9): 1-43.

Alves RRN, Souto WMS, Mourão JS (2010a) A Etnozoologia no Brasil: Importância, Status atual e Perspectivas. 1 ed. NUPEEA, Recife, PE, Brazil.

Alves RRN, Souto WMS, Barboza RRD (2010b) Primates in traditional folk medicine: a world overview. Mammal Review 40:155 - 180.

Alves RRN, Barboza RRD, Souto WMS (2010c) A Global overview of canids used in traditional medicines. Biodiversity and Conservation 19:1513-1522.

Alves RRN, Nogueira E, Araujo H, Brooks S (2010d) Bird-keeping in the Caatinga, NE Brazil. Human Ecology 38:147-156.

Alves RRN, Mendonça LET, Confessor MVA, Vieira WLS, Lopez LCS (2009a) Hunting strategies used in the semi-arid region of northeastern Brazil. Journal of Ethnobiology and Ethnomedicine 5:1-50.

Alves RRN, Léo Neto NA, Santana GG, Vieira WLS, Almeida WO (2009b) Reptiles used for medicinal and magic religious purposes in Brazil. Applied Herpetology 6:257-274.

Alves RRN, Lima JRF, Araújo HF (2012) The live bird trade in Brazil and its conservation implications: an overview. Bird Conservation International, doi 10.1017/S095927091200010X:1-13.

Alves RRN, Nishida AK (2002) A ecdise do caranguejo-uçá, Ucides cordatus L. (DECAPODA, BRACHYURA) na visão dos caranguejeiros. Interciencia 27:110-117.

Alves RRN, Nishida AK (2003) Aspectos socioeconômicos e percepção ambiental dos catadores de caranguejo-uçá Ucides cordatus cordatus (L. 1763) (Decapoda, Brachyura) do estuário do Rio Mamanguape, Nordeste do Brasil. Interciencia 28:36-43.

Alves RRN, Rosa IL (2005) Why study the use of animal products in traditional medicines? Journal of Ethnobiology and Ethnomedicine 1:1-5.

Alves RRN, Rosa IL (2007) Biodiversity, traditional medicine and public health: where do they meet? Journal of Ethnobiology and Ethnomedicine 3:9.

Alves RRN, Rosa IL (2012) Animals in Traditional Folk Medicine: Implications for Conservation. 1 ed. Springer-Verlag, Berlin Heidelberg.

Alves RRN, Rosa IL, Santana GG (2007) The Role of Animal-derived Remedies as Complementary Medicine in Brazil. BioScience 57: 949-955.

Alves RRN, Souto WMS (2010) Etnozoologia: conceitos, considerações históricas e importância. In: Alves RRN, Souto WMS, Mourão JS (eds) A Etnozoologia no Brasil: Importância, Status atual e Perspectivas. 1 ed. NUPEEA, Recife, PE, Brazil, pp. 19-40.

Alves RRN, Souto WMS (2011) Ethnozoology in Brazil: current status and perspectives. Journal of Ethnobiology and Ethnomedicine 7:22

Alves RRN, Vieira KS, Santana GG, Vieira WLS, Almeida WO, Souto WMS, Montenegro PFGP, Pezzuti JCB (2011) A review on human attitudes towards reptiles in Brazil. Environmental Monitoring and Assessment, Doi: 10.1007/ s10661-011-2465-0.

Alves RRN, Vieira WLS, Santana GG (2008) Reptiles used in traditional folk medicine: conservation implications. Biodiversity and Conservation 17:2037-2049. 
Anadón JD, Giménez A, Ballestar R (2010) Linking local ecological knowledge and habitat modelling to predict absolute species abundance on large scales. Biodiversity and Conservation 19:1443-1454.

Anderson K (1995) Culture and nature at the Adelaide Zoo: at the frontiers of'human'geography. Transactions of the Institute of British Geographers 20:275-294.

Anderson M, Denis R (1994) Improving Animal Based Transport: Options, Approaches, Issues and Impact. Technical Centre for Agricultural and Rural Cooperation, The Netherlands.

Andrews C (1990) The ornamental fish trade and fish conservation. Journal of Fish Biology 37:53-59.

Angulo A (2008) Consumption of Andean frogs of the genus Telmatobius in Cusco, Peru: Recommendations for their conservation. Traffic Bulletin 21:95-97.

Arriaga C, Jordan LVB (1999) Economics of Draught Animal Ownership in Smallholder campesino (peasant) Hill slope Agricultural Production Systems in the State of Mexico. Centre for Tropical Veterinary Medicine, University of Edinburgh, Edinburgh.

Ashwell D, Walston N (2008) An overview of the use and trade of plants and animals in traditional medicine systems in Cambodia. 1 ed. TRAFFIC Southeast Asia, Greater Mekong Programme, Ha Noi, Vietnam.

Ávila-Pires FD (1989) Zoonoses: hospedeiros e reservatórios. Cadernos de Saúde Pública 5:82-97.

Baenninger $\mathrm{R}$ (1995) Some consequences of animal domestication for humans. Anthrozoos: A Multidisciplinary Journal of The Interactions of People \& Animals 8:69-77.

Bagniewska J, MacDonald D (2010) Executive summary of the report Animal welfare, international development, biodiversity conservation - the road to peaceful coexistence University of Oxford.

Bailey N (2000) Global and Historical Perspectives on Market Hunting: Implications for the African Bushmeat Crisis. Sustainable Development and Conservation Biology - University of Maryland and Bushmeat Crisis Task Force Silver Spring, Maryland.

Bakarr MI, Fonseca G, Mittermeier RA, Rylands AB, Painemilla KW (2001) Hunting and bushmeat utilisation in the African rainforest: perspectives towards a blueprint for conservation action. Conservation International, Washington, DC.

Baky J (1980) Human and Animals. 1 ed. The HW Wilson Company, New York.

Baratay E, Hardouin-Fugier E (2004) Zoo: A history of zoological gardens in the West. 1 ed. Reaktion books.

Barsa E (1969) Os animais e a subsistência. . Enciclopédia Britânica, São Paulo.

Basset Y, Charles E, Hammond DS, Brown VK (2001) Short term effects of canopy openness on insect herbivores in a rain forest in Guyana. Journal of Applied Ecology 38:1045-1058.

Basset Y, Novotny V, Miller SE, Pyle R (2000) Quantifying biodiversity: experience with parataxonomists and digital photography in Papua New Guinea and Guyana. BioScience 50:899-908.

Basso KH (1996) Wisdom Sits in Places: Landscape and Language Among the Western Apache. 1 ed. University of New Mexico Press. 
BBC WS (2007) National Symbols. [http://downloads.bbc.co.uk/china/assets/pdf/national_symbols_worksheet.pdf]

Beardsworth A, Bryman A (2001) The wild animal in late modernity: The case of the Disneyization of zoos. Tourist Studies 1:83-104.

Beck AM, Katcher AH (1996) Between pets and people: The importance of animal companionship. 1 ed. Purdue Univ Pr.

Begossi A, Clauzet M, Figueiredo JL, Guarano L, Lima R, Lopes PFM, Souza MR, Silva AL, Silvano RAM (2008) Are biological species and high-ranking categories real? Fish folk taxonomy in the Atlantic Forest and the Amazon (Brazil). Current Anthropology 49:291-302.

Begossi A, Silvano RAM, Amaral BD, Oyakama OT (1999) Uses of Fish and Game by Inhabitants of an Extrative Reserve (Upper Juruá, Acre, Brazil). Environment, Development and Sustainability 1:73-93.

Bell JC, Palmer SR, Payne JM (1988) The zoonoses (infections transmitted from animals to man). $1 \mathrm{ed}$. Arnold, London.

Bengis RG, Leighton FA, Fischer JR, Artois M, Mörner T, Tate CM (2004) The role of wildlife in emerging and re-emerging zoonoses. Rev. sci. tech. Off. int. Epiz. 23:497-511.

Bennett EL, Robinson JG (2000) Hunting of Wildlife in Tropical Forests. The World Bank Environment Department Papers, 1-42.

Bennett ET (1829) The Tower menagerie: comprising the natural history of the animals contained in that establishment; with anecdotes of their characters and history. 1 ed. Jennings, London.

Berkes F (1999) Sacred Ecology: Traditional ecological knowledge and resource management. 1 ed. Taylor \& Francis, Philadelphia, USA.

Berkes F (2001) Religious traditions and biodiversity. Encyclopedia of Biodiversity 5:109-120.

Berkes F (2008) Sacred Ecology. 1 ed. Routledge, London and New York.

Bezerra DMM, Araujo HFP, Alves RRN (2012) Captura de aves silvestres no semiárido brasileiro: técnicas cinegéticas e implicações para conservação. Tropical Conservation Science 5:50-66.

Bezzel E, Prinzinger R (1990) Ornithologie. 1 ed. Verlag Eugen Ulmer, Stuttgart.

Biebuyck DP, Van den Abbeele N (1984) The power of headdresses: a crosscultural study of forms and functions. Leopold III Foundation for Exploration \& Nature Conservation, Brussels.

Bishop LJ, Nolen AL (2001) Animals in research and education: ethical issues. Kennedy Institute of Ethics Journal 11:91-113.

Bogart RE, Duberstein JN, Slobe DF (2009) Strategic communications and its critical role in bird habitat conservation: understanding the socialecological landscape. Proceedings of the fourth international partners in flight conference. Texas, USA. Pp 441-452.

Bondad-Reantaso MG, Subasinghe RP, Josupeit H, Junning C, Xiaowei Z (2012) The role of crustacean fisheries and aquaculture in global food security: Past, present and future. Journal of Invertebrate Pathology 110:158-165.

Boonen R, Aerts S, Meganck M, De Tavernier J (2012) Feed efficiencies in animal production: a non-numerical analysis. Climate Change and Sustainable Development: Ethical Perspectives on Land Use and Food Production. 1 ed. Wageningen Academic Pub, pp. 196-201.

Bowman JC (1977) Animals for man. 1 ed. Edward Arnold., London. 
Bradbury H (2002) The gharry horses of gonder project management interventions to improve the welfare of the gharry horses of Gonder Ethiopia. MSc. Dissertation. University of Wales, Bancor, UK.

Broad S (2001) The nature and extent of legal and illegal trade in wildlife. Hughes Hall, International and Africa Resources Trust. TRAFFIC, Cambridge.

Brodie SJ, Biley FC (1999) An exploration of the potential benefits of petfacilitated therapy. Journal of Clinical Nursing 8:329-337.

Brown C (2004) Emerging zoonoses and pathogens of public significance - an overview. Revue Scientifique et Technique, Office International Epizooties 23:435-442.

Bryant CD (1979) The zoological connection: Animal-related human behavior. Social Forces 58:399-421.

Bueno FGC (2009) Homem que não ladra, cão que não morde: A Comunicação Interespécies marcando a Cultura pós-moderna. MSc. dissertation, Universidade de Sorocaba, Sorocaba, SP.

Burgos S, Burgos SA (2007) Influence of exotic bird and wildlife trade on avian influenza transmission dynamics: Animal-human Interface. International Journal of Poultry Science 6:535-538.

Buscher B, Wolmer W (2007) Introduction: The politics of engagement between biodiversity conservation and the social sciences. Conservation and Society 5:1-21.

Call E (2006) Mending the Web of Life: Chinese Medicine and Species Conservation. 1 ed. International Fund for Animal Welfare, Massachusetts.

Callicott JB (1994) Earth's Insights: A Multicultural Survey of Ecological Ethics from the Mediterranean Basin to the Australian Outback. 1 ed. University of California Press, Berkeley CA.

Carrete M, Tella JL (2008) Wild-bird trade and exotic invasions: a new link of conservation concern? Frontiers in Ecology and the Environment 6:207-211.

Carvalho JCM (1951) Relações entre os índios do Alto Xingu ea fauna regional. Publicações avulsas do Museu Nacional. $32 \mathrm{p}$.

Castello L (2004) A method to count pirarucu Arapaima gigas: Fishers, assessment, and management. North American Journal of Fisheries Management 24:379-389.

Center AH, Walsh FE (1981) Public Relations Practices: Case Studies. 1 ed. Prentice-Hall, Inc., New Jersey.

Ceriaco LMP (2012) Human attitudes towards herpetofauna: The influence of folklore and negative values on the conservation of amphibians and reptiles in Portugal. Journal of Ethnobiology and Ethnomedicine 8:8.

Ceríaco LMP (2010) Human Attitudes Towards Herpetofauna: How preferences, fear and beliefs can influence the conservation of reptiles and amphibians. MSc. dissertation, Universidade de Évora, Évora.

Ceríaco LMP, Marques MP, Madeira NC, Vila-Viçosa CM, Mendes P (2011) Folklore and traditional ecological knowledge of geckos in Southern Portugal: implications for conservation and science. Journal of Ethnobiology and Ethnomedicine 7:26.

Chan SW (2006) Religious Release of Birds in Hong Kong. MSc. dissertation, University of Hong Kong. 
Chapin FS, Whiteman G (1998) Sustainable development of the boreal forest: interaction of ecological, social, and business feedbacks. Conservation Ecology 2:12.

Chapin III FS, Zavaleta ES, Eviner VT, Naylor RL, Vitousek PM, Reynolds HL, Hooper DU, Lavorel S, Sala OE, Hobbie SE (2000) Consequences of changing biodiversity. Nature 405:234-242.

Chauvet JM, Deschamps EB, Hillaire C, Bahn P (1996) Dawn of art: the Chauvet Cave: the oldest known paintings in the world. 1 ed. HN Abrams.

Check E (2004) Health concerns prompt US review of exotic-pet trade. Nature 427:277-277.

Chemas RC (2010) A zooterapia no âmbito da medicina civilizada. I. Organoterapia humana e animal stricto sensu. In: Costa-Neto EM, Alves RRN (eds) Zooterapia: Os Animais na Medicina Popular Brasileira. 1 ed. NUPEEA, Recife, PE, Brazil, pp. 75-102.

Chesterton GK (1912) Aesop's Fables, Introduction. 1 ed. Crown Publishers.

Child B (1996) The practice and principles of community-based wildlife management in Zimbabwe: the CAMPFIRE programme. Biodiversity and Conservation 5:369-398.

Chivian E (2002) Biodiversity: Its Importance to Human Health. Center for Health and the Global Environment. Harvard Medical School Cambridge, USA.

Chomel BB (2002) Zoonosis bacterianas de aparición reciente. Rev Panam Salud Publica 11:50-55.

Chomel BB (2003) Control and prevention of emerging zoonoses. Journal of veterinary medical education 30:145-147.

Chomel BB, Belotto A, Meslin FX (2007) Wildlife, exotic pets, and emerging zoonoses. Emerging Infectious Diseases 13:6-11.

Chorilli M, Michelin DC, Salgado HRN (2009) Animais de laboratório: o camundongo. Revista de Ciências Farmacêuticas Básica e Aplicada 28:11-23.

Clark S, Rehding A (2001) Introduction. In: Clark S, Rehding A (eds) Music theory and natural order from the renaissance to the early twentieth century. $1 \mathrm{ed}$. Cambridge University Press, Cambridge, MA, pp. 1-13.

Clark $X$ (1879) Animal music, its nature and origin. The American Naturalist 13:209-223.

Clary RM, Wandersee JH (2005) Through the looking glass: the history of aquarium views and their potential to improve learning in science classrooms. Science \& Education 14:579-596.

Claus CA, Chan KMA, Satterfield T (2010) The roles of people in conservation. In: Sodhi NS, Ehrlich PR (eds) Conservation biology for all. 1 ed. Oxford University Press, New York, pp. 262-283.

Cleaveland S, Laurenson MK, Taylor LH (2001) Diseases of humans and their domestic mammals: pathogen characteristics, host range and the risk of emergence. Philosophical Transactions of the Royal Society of London. Series B: Biological Sciences 356:991-999.

Clément $D$ (1998) The historical foundations of ethnobiology (1860-1899). Journal of Ethnobiology 18:161-161.

Cleva S (2006) U. S. Conservation laws and treaties: support for the web. In: Call $E$ (ed) Mending the web of life: Chinese Medicine \& Species Conservation. 1 ed. Signature Book Printing, Inc., Beijing, pp. 199-214.

Clottes J (2003) Chauvet Cave: the art of earliest times. 1 ed. University of Utah Press. 
Collar NJ, Long AJ, Jaime PRG (2007) Birds and People: Bonds in a Timeless Journey. 1 ed. BirdLife International.

Conard NJ (2003) Palaeolithic ivory sculptures from southwestern Germany and the origins of figurative art. Nature 426: 830-837.

Cruikshank J (2005) Do Glaciers Listen? Local Knowledge, Colonial Encounters, and Social Imagination. $1 \mathrm{ed}$. UBC Press, Vancouver BC.

Cullen Jr L, Bodmer RE, Padua CV (2000) Effects of hunting in habitat fragments of the Atlantic forests, Brazil. Biological Conservation 95:49-56.

Cunningham $A B$ (2001) Applied ethnobotany: people, wild plant use and conservation. 1 ed. Earthscan/James \& James.

Cushing DH (1988) The provident sea. 1ed. Cambridge Univ Pr, Cambridge.

Danielsen F, Balete DS, Poulsen MK, Enghoff M, Nozawa CM, Jensen AE (2000) A simple system for monitoring biodiversity in protected areas of a developing country. Biodiversity and Conservation 9:1671-1705.

De Smet PAGM (1991) Is there any danger in using traditional remedies? . J Ethnopharmacol. 32:43-50.

Delgado CL (1999) Livestock to 2020: The next food revolution. Intl Food Policy Res Inst.

Delgado CL, Wada N, Rosegrant MW, Meijer S, Ahmed M (2003) Outlook for fish to 2020: meeting global demand. Food Policy Report. International Food Policy Research Institute, Washington (D. C.).

Denis R (1999) Meeting the Challenges of Animal Based Transport. Intermediate Technology Publications, London.

Deschênes B (2002) "Inuit Throat-Singing". Musical Traditions. The Magazine for Traditional Music Throughout the World. [http://www.mustrad.org.uk/articles/inuit.htm]

Dias TLP, Leo Neto NA, Alves RRN (2011) Molluscs in the marine curio and souvenir trade in NE Brazil: species composition and implications for their conservation and management. Biodiversity and Conservation 20:23932405.

Dickman AJ (2010) Complexities of conflict: the importance of considering social factors for effectively resolving human-wildlife conflict. Animal Conservation 13:458-466.

Digard JP (1990) L'homme et les animaux domestiques: anthropologie d'une passion. 1 ed. Fayard, Paris.

Dossey AT (2010) Insects and their chemical weaponry: New potential for drug discovery. Natural product reports 27:1737-1757.

Drew JA (2005) Use of Traditional Ecological Knowledge in Marine Conservation. Conservation Biology 19:1286-1293.

Ehrlich PR, Ehrlich AH (2008) The dominant animal: human evolution and the environment. 1 ed. sland $\mathrm{Pr}$.

Emery KF (2007) Assessing the impact of ancient Maya animal use. Journal for Nature Conservation 15:184-195.

European Commission (2011) Biodiversity and Health. http://ec.europa.eu/environment/integration/research/newsalert/pdf/FB2.pdf Accessed 29 April 2012

Fa JE, Currie D, Meeuwig J (2003) Bushmeat and food security in the Congo Basin: linkages between wildlife and people's future. Environmental Conservation 30:71-78. 
Fagundes DJ, Taha MO (2004) Modelo animal de doença: critérios de escolha e espécies de animais de uso corrente. Acta Cir Bras 19:59-65.

FAO (2009a) Feeding the world in 2050. Food and Agriculture Organization of the United Nations, Rome. Report.

FAO (2009b) The State of Food and Agriculture, Livestock in the balance. Food and Agriculture Organization, Rome.

FAO (2009c) The state of world fisheries and aquaculture 2008. FAO Fisheries Department. , Rome (Italy).

FAO (2011) Global Capture Production Statistics Dataset 1950-2009 and Global Aquaculture Production Statistics dataset (Quantity and Value) 19502009. [http://www.fao.org/fishery/statistics/software/fishstat/en]

FAO (2010) What future for inland fisheries?. The State of World Fisheries and Aquaculture 2010 FAO, Food and Agriculture Organization of the United Nations, Rome, Italy.

FAO (2012) Fish utilization. [http://www.fao.org/fishery/topic/2888/en]

Faulkner DJ (1998) Marine natural products. Natural product reports 15:113-158.

Ferguson NM, Cummings DAT, Cauchemez S, Fraser C, Riley S, Meeyai A, lamsirithaworn S, Burke DS (2005) Strategies for containing an emerging influenza pandemic in Southeast Asia. Nature 437:209-214.

Fernandes-Ferreira H, Mendonça SV, Albano C, Ferreira FS, Alves RRN (2012a) Hunting, use and conservation of birds in Northeast Brazil. Biodiversity and Conservation, 21 (1): 221-244.

Fernandes-Ferreira H, Cruz RL, Borges-Nojosa DM, Alves RRN (2012b) Crenças Associadas a Serpentes no Estado do Ceará, Nordeste do Brasil. Sitientibus 11:153-163.

Fischer-Kowalski M, Weisz H (1999) Society as hybrid between material and symbolic realms: Toward a theoretical framework of society-nature interaction. Advances in Human Ecology 8:215-252.

Fitter RSR (1986) Wildlife for man: how and why we should conserve our species. 1 ed. Collins, London, London.

Foster MS, James SR (2002) Dogs, Deer, or Guanacos: Zoomorphic Figurines from Pueblo Grande, Central Arizona. Journal of Field Archaeology 29:165176.

Francis ST (1991) The origins of dance: The perspective of primate evolution. Dance Chronicle 14:203-220.

Franke J, Telecky TM (2001) Reptiles as pets: an examination of the trade in live reptiles in the United States. Report. Humane Society of the United States, Washington (DC).

Franklin A (1999) Animals \& modern cultures - A sociology of Human-Animal Relations in Modernity. 1 ed. Sage, London.

Friend M (2006) Disease emergence and resurgence: the wildlife-human connection. US Department of the Interior, US Geological Survey, Report.

Fusetani N (2000) Drugs from the Sea. 1 ed. S Karger Pub.

García-Quijano CG, Pitchon A (2010) Aquatic Ethnobiology. In: Stepp JR (ed) Ethnobiology. 1 ed. Encyclopedia of Life Support Systems (EOLSS),UNESCO, Oxford, UK.

Garcia G (2012) A fauna brasileira escondida na Catedral da Sé. [http://www.saopauloantiga.com.br/a-fauna-brasileira-na-catedral-da-se/]

Accessed 29 April 2012 
Geist HJ, Lambin EF (2002) Proximate causes and underlying driving forces of tropical deforestation. BioScience 52:143-150.

Gilbert M, Sokha C, Joyner PH, Thomson RL, Poole C (2012) Characterizing the trade of wild birds for merit release in Phnom Penh, Cambodia and associated risks to health and ecology. Biological Conservation 153:10-16.

Gillingham S (2001) Social organization and participatory resource management in Brazilian ribeirinho communities: A case study of the Mamiraua Sustainable Development Reserve, Amazonas. Society \&Natural Resources 14:803-814.

Givens DI, Allison R, Cottrill B, Blake JS (2004) Enhancing the selenium content of bovine milk through alteration of the form and concentration of selenium in the diet of the dairy cow. Journal of the Science of Food and agriculture 84:811-817.

Glaw F, Vences M, Randrianiania RD (2008) Killed aye-aye (Daubentonia madagascariensis) exposed on the gallows in northeastern Madagascar. Lemur News 13:6-7.

Glickman LT, Fairbrother A, Guarino AM, Bergman HL, Buck WB (1991) Animals as sentinels of environmental health hazards. National Research Council, Committee on Animals as Monitors of Environmental Hazards, Washington, DC.

Goe MR, McDowell RE (1980) Animal traction: guidelines for utilization. 1 ed. Cornell International agriculture, New York.

Goh TY, O'Riordan RM (2007) Are tortoises and freshwater turtles still traded illegally as pets in Singapore? Oryx 41:97-100.

Gonwouo LN, Rödel MO (2008) The importance of frogs to the livelihood of the Bakossi people around Mount Manengouba, Cameroon, with special consideration of the Hairy Frog, Trichobatrachus robustus. Salamandra 44:23-34.

Gössling S, Kunkel T, Schumacher K, Zilger M (2004) Use of molluscs, fish, and other marine taxa by tourism in Zanzibar, Tanzania. Biodiversity and Conservation 13:2623-2639.

Grey M, Blais MA, Vincent ACJ (2005) Magnitude and trends of marine fish curio imports to the USA. Oryx 39:413-420.

Gross DR (1975) Protein Capture and Cultural Development in the Amazon Basin. American Anthropologist 77:526-549.

Haberl H, Winiwarter V, Andersson K, Ayres RU, Boone C, Castillo A, Cunfer G, Fischer-Kowalski M, Freudenburg WR, Furman E (2006) From LTER to LTSER: Conceptualizing the socioeconomic dimension of long-term socioecological research. Ecology and Society 11:13.

Haggan N (2011) You don't know what you've got 'Til it's Gone: The Case for Spiritual Values in Marine Ecosystem Management. In: Ommer RE, Perry RI, Cochrane K, Cury P (eds) World Fisheries: A Social-Ecological Analysis. 1 ed. Wiley Online Library, Oxford, UK, pp. 224-246.

Hamblin NL (1985) The role of marine resources in the Maya economy: a case study from Cozumel, Mexico. Prehistoric lowland Maya environment and subsistence economy 1 ed. Cambridge: Harvard university, The Peabody museum of american archaeology and ethnology, pp. 159-173.

Hammond PB, Aronson AL (1964) Lead poisoning in cattle and horses in the vicinity of a smelter. Annals of the New York Academy of Sciences 111:595611. 
Hanazaki N, Alves RRN, Begossi A (2009) Hunting and use of terrestrial fauna used by Caicaras from the Atlantic Forest coast (Brazil). Journal of Ethnobiology and Ethnomedicine 5:36.

Hand D (2002) Football, cultural identities and the media: a research agenda. 1 ed. CABI Publishing.

Hardy A (2003) Animals, disease, and man: making connections. Perspectives in biology and medicine 46:200-215.

Heffner HE (1999) The symbiotic nature of animal research. Perspectives in biology and medicine 43:128-139.

Herold P, Schlechter P, Scharnhölz R (2009) Modern use of horses inorganic farming. [http://hippotese.free.fr/blogdocs5/agri-bio-Horses-in-organicfarming_FECTU-IGZ.pdf] Accessed 05 April 2012

Herrmann T, Costina MI, Costina AM (2010) Roost sites and communal behavior of Andean condors in Chile. Geographical Review 100:246-262.

Holley D (2009) The History of Modern Zoology. [http://suite101.com/article/thehistory-of-modern-zoology-a135787] Accessed 05 April 2012

Hoover C (1998) The US role in the international live reptile trade: Amazon tree boas to Zululand dwarf chameleons. TRAFFIC North America

Hopkins K, Beard M (2011) The Colosseum. 1 ed. Profile Books

Hoppál M (2006) Music of Shamanic Healing. In: Kilger G (ed) Macht Musik. Musik als Glück und Nutzen für das Leben. 1 ed. Wienand Verlag, Köln

Hulshof KF, van Erp-Baart MA, Anttolainen M, Becker W, Church SM, Couet C, Hermann-Kunz E, Kesteloot H, Leth T, Martins I (1999) Intake of fatty acids in Western Europe with emphasis on trans fatty acids: the transfair study. European Journal of Clinical Nutrition 53:143-157.

Hunt B, Vincent ACJ (2006) Scale and sustainability of marine bioprospecting for pharmaceuticals. AMBIO: A Journal of the Human Environment 35:57-64.

Hurn S (2012) Humans and Other Animals: Cross-Cultural Perspectives on Human-Animal Interactions. PlutoPress, London.

IFAW (2011) Traditional Medicine. [http://www.ifaw.org/sites/default/files/Q\&A\%20Traditional\%20medicine.pdf] Accessed 30 March 2012

Inskip C, Zimmermann A (2009) Human-felid conflict: a review of patterns and priorities worldwide. Oryx 43:18-34.

Ireland CM, Copp BR, Foster MP, McDonald LA, Radisky DC, Swersey JC (1993) Biomedical potential of marine natural products. Marine Biotechnology 1:143.

Jacobson SK, Duff MD (1998) Training idiot savants: the lack of human dimensions in conservation biology. Conservation Biology 12:263-267.

Jepson P, Ladle RJ (2005) Bird-keeping in Indonesia: conservation impacts and the potential for substitution-based conservation responses. Oryx 39:442448.

Johannes RE (1993) Integrating traditional ecological knowledge and management with environmental impact assessment. In: Inglis JT (ed) Traditional Ecological Knowledge: Concepts and Cases. 1 ed. International Program on Traditional Ecological Knowledge and International Development Research Centre, Ottawa, Canada, pp. 33-39.

Jordão LR, Faleiros RR, Aquino Neto HM (2011) Animais de trabalho e aspectos éticos envolvidos: revisão crítica. Acta Veterinaria Brasilica 5:33-40. 
Jorgenson $\mathrm{J}$ (1997) Therapeutic use of companion animals in health care. Journal of Nursing Scholarship 29:249-254.

Jorgenson JP (1998) The impact of hunting on wildlife in the Maya Forest of Mexico. Timber, tourists and temples: Conservation and development in the Maya forests of Belize, Guatemala and Mexico. 1 ed. Island Press, Washington D.C., pp. 179-194.

Kahn LH (2006) Confronting Zoonoses, Linking Human and Veterinary Medicine. Emerging Infectious Diseases 12:556-561.

Kalof L, Resl B (2007) A Cultural History of Animals: In antiquity. 1 ed. Berg

Kaltenborn B, Bjerke T, Nyahongo J, Williams D (2006) Animal Preferences and Acceptability of Wildlife Management Actions around Serengeti National Park, Tanzania. Biodiversity and Conservation 15:4633-4649.

Karesh WB, Cook RA, Gilbert M, Newcomb J (2007) Implications of wildlife trade on the movement of avian influenza and other infectious diseases. Journal of Wildlife Diseases 43:S55-S59.

Kingdon J, Pagel M (1997) The Kingdon field guide to African mammals. 1 ed. Academic Press London.

Kirkwood JK (1987) Animals at home--pets as pests: a review. Journal of the Royal Society of Medicine 80:97-100.

Kisling VN (2001a) Ancient collections and menageries. In: Kisling VN (ed) Zoo and aquarium history: ancient animal collections to zoological gardens. $1 \mathrm{ed}$. CRC Press, London, pp. 1-47.

Kisling VN (2001b) Zoo and aquarium history: Ancient animal collections to zoological gardens. 1 ed. CRC Press, London.

Klemens MW, Thorbjarnarson JB (1995) Reptiles as a food resource. Biodiversity and Conservation 4:281-298.

Klingender F (1971) Animals in Art and Thought to the End of the Middle Ages. 1 ed. Routledge

Kortlandt $A$ (1986) The use of stone tools by wild-living chimpanzees and earliest hominids. Journal of human Evolution 15:77-132.

Koster J (2008) The impact of hunting with dogs on wildlife harvests in the Bosawas Reserve, Nicaragua. Environmental Conservation 35:211-220.

Kothari A (2007) Birds in our lives. 1 ed. Universities Press,

Krauss H (2003) Zoonoses: infectious diseases transmissible from animals to humans. 1 ed. Amer Society for Microbiology Press.

Kruse H, Kirkemo AM, Handeland K (2004) Wildlife as source of zoonotic infections. Emerging Infectious Diseases 10:2067-2072.

Kunin WE, Lawton JH (1996) Does biodiversity matter? Evaluating the case for conserving species. In: Gaston KJ (ed) Biodiversity: a biology of numbers and differences. 1 ed. Oxford: Blackwell Science, pp. 283-308.

Kunz GF (1916) Ivory and the Elephant in Art. 1 ed.Doubleday, Page and Co., New York.

Kunze G (2000) Tiergarten Schönbrunn. 1 ed. LW Werbe- und VerlagsgmbH, Vienna.

Kyselý R (2008) Frogs as a part of the Eneolithic diet. Archaeozoological records from the Czech Republic (Kutná Hora-Denemark site, Rivnác Culture). Journal of Archaeological Science 35:143-157.

Lawergren B (1988) The Origin of Musical Instruments and Sounds. Anthropos 83:31-45. 
Lawrence EA (1990) Symbol of a nation: the bald eagle in American culture. Journal of American Culture 13:63-69.

Lawrence EA (1997) Hunting the wren: transformation of bird to symbol: a study in human-animal relationships. 1 ed. Univ Tennessee Press.

Leakey RE (1981) The making of mankind. 1 ed. Dutton New York.

Lee SKH (1999) Trade in traditional medicine using endangered species: an international context. Proceedings of the second Australian Symposium on traditional medicine and wildlife conservation, Melbourne Australia.

Leo Neto NA, Alves RRN (2010) A Natureza sagrada do Candomblé: análise da construção mística acerca da Natureza em terreiros de candomblé no Nordeste de Brasil. Interciencia 35:568-574.

Léo Neto NA, Brooks SE, Alves RRN (2009) From Eshu to Obatala: animals used in sacrificial rituals at Candomble "terreiros" in Brazil. Journal of Ethnobiology and Ethnomedicine 5:1-23.

Leo Neto NA, Mourão JS, Alves RRN (2011) "It all begins with the head": initiation rituals and the symbolic conceptions of animals in Candomblé. Journal of Ethnobiology 31:244-261.

Leo Neto NA, Voeks RA, Dias TLP, Alves RRN (2012) Mollusks of Candomble: symbolic and ritualistic importance. Journal of Ethnobiology and Ethnomedicine 8:10.

Lidicker Jr WZ, Meffe GK, Noss RF, Jacobson SK (1998) Revisiting the Human Dimension in Conservation Biology. Conservation Biology 12:1168-1172.

Lilley B, Lammie P, Dickerson J, Eberhard M (1997) An increase in hookworm infection temporally associated with ecologic change. Emerging Infectious Diseases 3:391-393.

Liu X, Mcgarrity ME, Li Y (2012) The influence of traditional Buddhist wildlife release on biological invasions. Conservation Letters 5:107-114.

Lopes PFM, Silvano R, Begossi A (2010) Da Biologia a Etnobiologia - Taxonomia e etnotaxomia, ecologia e etnoecologia. In: Alves RRN, Souto WMS, Mourão JS (eds) A Etnozoologia no Brasil: Importância, Status atual e Perspectivas. 1 ed. NUPEEA, Recife, PE, Brazil, pp. 67-94.

Lugira AM (2009) African Traditional Religion. 1 ed. Chelsea House Pub, New York.

Lunn KE, Noriega MJV, Vincent ACJ (2008) Souvenirs from the sea: an investigation into the curio trade in echinoderms from Mexico. Traffic Bulletin 22:19-32.

Lynam T, Cunliffe R, Mapaure I (2004) Assessing the importance of woodland landscape locations for both local communities and conservation in Gorongosa and Muanza Districts, Sofala Province, Mozambique. Ecology and Society 9:1-24.

Maass $P$ (1999) The cultural context of biodiversity conservation. In: Markussen M, Buse R, Garrelts H, Costa MAM, Menzel S, Marggraf R (eds) Valuation and Conservation of Biodiversity: Interdisciplinary Perspectives on the Convention on Biological Diversity 1ed. Springer, Berlim, pp. 315-342.

MacKinney LC (1946) Animal substances in materia medica. Journal of the history of medicine and allied sciences 1:149-170.

Malamud R, Kalof L, Pohl-Resl B (2007) A Cultural History of Animals in the Modern Age. 1ed. Berg Publishers, Oxford, UK.

Manning A, Serpell J (1994) Animals and human society: Changing perspectives. 1 ed. Psychology Press, London. 
Marques JGW (1995) Pescando pescadores: etnoecologia abrangente no baixo São Francisco alagoano. 1 ed. NUPAUB-USP, São Paulo, BR.

Marques JGW (1997) Fauna medicinal: Recurso do ambiente ou ameaça à biodiversidade? Mutum 1:4

Mascia MB, Brosius JP, Dobson TA, Forbes BC, Horowitz L, McKean MA, Turner NJ (2003) Conservation and the social sciences. Conservation Biology 17:649650.

Masson MA (1999) Animal Resource Manipulation in Ritual and Domestic Contexts at Postclassic Maya Communities. World Archaeology 31:93-120.

Masson MA, Peraza Lope C (2008) Animal use at the Postclassic Maya center of Mayapán. Quaternary International 191:170-183.

Mathews FS (1910) Field book of wild birds and their music. 1 ed. The Knickerbocker Press, New York.

Matuszek S (2010) Animal-facilitated therapy in various patient populations: systematic literature review. Holistic Nursing Practice 24:187.

McClure HE, Chaiyaphun S (1971) The sale of birds at the Bangkok "Sunday Market", Thailand. Natural History Bulletin of the Siam Society 24:41-78.

McCluskey BJ (2003) Use of sentinel herds in monitoring and surveillance systems Salman. Animal disease surveillance and survey systems: methods applications lowa. 1 ed. lowa State Press, pp. 119-133.

McKillop H (1984) Prehistoric Maya reliance on marine resources: Analysis of a midden from Moho Cay, Belize. Journal of Field Archaeology 11:25-35.

McKillop HI (1985) Prehistoric exploitation of the manatee in the Maya and circum-Caribbean areas. World Archaeology 16:337-353.

McNeely JA (2001) Religions, traditions and biodiversity. COMPAS Magazine, 20-22.

Meine C, Soule M, Noss RF (2006) “A Mission Driven Discipline": the Growth of Conservation Biology. Conservation Biology 20:631-651.

Mendonça LET (2012) Atividades cinegéticas por populações rurais e urbanas do município de Pocinhos, Estado da Paraíba, Brasil: uma abordagem etnozoológica. MSc. dissertation, Universidade Federal da Paraíba.

Merrill BR (1990) 'Behold the Lamb of God': The Savior's Use of Animals as Symbols. [http://www.schoolofabraham.com/Animals\%20as\%20Symbols.htm]. Accessed 30 April 2012.

Michael K, Lambeth L (2000) Fisheries management by communities: a manual on promoting the management of subsistence fisheries by Pacific Island communities. 1 ed. Secretariat of the Pacific Community. Multipress, Noumea, New Caledonia.

Moazami M (2005) Evil Animals in the Zoroastrian Religion. History of Religions 44:300-317.

NBSAP, National Biodiversity Strategy and Action Plan (2000). Report United Nations Environment Programme.

Mohneke M, Onadeko AB, Hirschfeld M, Rödel MO (2010) Fried and dried: amphibians in local and regional food markets in West Africa. Traffic Bulletin 22:117-128.

Mohneke M, Onadeko AB, Rödel MO (2009) Exploitation of frogs - a review with a focus on West Africa. Salamandra 45:193-202.

Moquin-Tandon A (1861) Elements of medical zoology. 1 ed. Baillière. 
Mora C, Myers RA, Coll M, Libralato S, Pitcher TJ, Sumaila RU, Zeller D, Watson R, Gaston KJ, Worm B (2009) Management effectiveness of the world's marine fisheries. PLoS Biology 7:e1000131.

Morgado MA (1993) Animal trademark emblems on fashion apparel: A semiotic interpretation. Clothing and Textiles Research Journal 11:31-38.

Morin-Labatut G, Akatar S (1992) Traditional Knowledge: a resource to manage and share. Development 4: 24-30.

Morris D (2011) A short history of zoos. In: Rees PA (ed) An introduction to zoo biology and management. 1 ed. Wiley-Blackwell, pp. 31-48.

Morris R, Morris D (1965) Men and snakes. 1 ed. McGraw-Hill,

Mourão JS, Araujo HFP, Almeida FS (2006) Ethnotaxonomy of mastofauna as practised by hunters of the municipality of Paulista, state of ParaíbaBrazil. Journal of Ethnobiology and Ethnomedicine 2:7.

Mourão JS, Nordi N (2002) Comparações entre as Taxonomias Folk e Científica para peixes do Estuário do Rio Mamanguape, Paraíba-Brasil. Interciencia 27:664-668.

Mourão JS, Nordi N (2003) Etnoictiologia de Pescadores Artesanais do Estuário do Rio Mamanguape, Paraíba, Brasil. Boletim do Instituto de Pesca 29:9-17.

Mourão JS, Nordi N (2006) Pescadores, peixes, espaço e tempo: uma abordagem Etnoecológica. Interciencia 31:358-363.

Mullan B, Marvin G (1998) Zoo culture. 1 ed. Univ of Illinois Pr.

Nakanishi K (1999) An historical perspective of natural products chemistry. In: Ushio S (ed) Comprehensive Natural Products Chemistry. 1 ed. Elsevier Science B.V., Amsterdam, pp. 23-40.

Nash SV (1993) Sold for a song The trade in Southeast Asian non-cities birds. Report, Traffic International. Cambridge.

Nasi R, Brown D, Wilkie D, Bennett E, Tutin C, van Tol G, Christophersen T (2008) Conservation and use of wildlife-based resources: the bushmeat crisis. Secretariat of the Convention on Biological Diversity, Montreal, and Center for International Forestry Research (CIFOR), Bogor.

National Institutes of Health ( 1987) The health benefits of pets (1988-216-107). 1 ed. US Government Printing Office, Washington, DC.

Naylor RL, Goldburg RJ, Primavera JH, Kautsky N, Beveridge MCM, Clay J, Folke C, Lubchenco J, Mooney H, Troell M (2000) Effect of aquaculture on world fish supplies. Nature 405:1017-1024.

Naylor RT (2005) The underworld of ivory. Crime, law and social change 42:261295.

Netting FE, Wilson CC, New JC (1987) The human-animal bond: Implications for practice. Social Work 32:60-64

Neufeld E (1973) Fabrication of Objects from Fish and Sea Animals in Ancient Israel. Journal of the Ancient Near Eastern Society of Columbia University 5:314-315.

Newing $\mathrm{H}$ (2001) Bushmeat hunting and management: implications of duiker ecology and interspecific competition. Biodiversity and Conservation 10:99118.

Newing $H$ (2010) Bridging the gap: interdisciplinarity, biocultural diversity and conservation. In: Pretty J, Pilgrim S (eds) Nature and Culture: Revitalising the Connection. 1 ed. Earthscan, London, UK, pp. 23-40.

Nightingale F (1969) Notes on nursing. 1 ed. Dover Publications, New York. 
Nikoloudis S (2001) Animal sacrifice in the Mycenaean world. Journal of Prehistoric Religion 15:32-38.

Nishida AK, Nordi N, Alves RRN (2006a) Mollusc Gathering in Northeast Brazil: An Ethnoecological Approach. Human Ecology 34:133-145.

Nishida AK, Nordi N, Alves RRN (2006b) Molluscs production associated to lunar-tide cycle: a case study in Paraíba State under ethnoecology viewpoint. Journal of Ethnobiology and Ethnomedicine 2:6.

Nordi N, Nishida AK, Alves RRN (2009) Effectiveness of Two Gathering Techniques for Ucides cordatus in Northeast Brazil: Implications for the Sustainability of Mangrove Ecosystems. Human Ecology 37:121-127.

Norris M (1985) Beasts of the Modern Imagination: Darwin, Nietzsche, Kafka, Ernst, and Lawrence. 1 ed. Johns Hopkins University Press, Baltimore, MD.

Noss $R$ (1999) Is there a special conservation biology? Ecography 22:113-122.

Novotny V, Basset Y, Miller SE, Weiblen GD, Bremer B, Cizek L, Drozd P (2002) Low host specificity of herbivorous insects in a tropical forest. Nature 416:841-844.

Ntiamoa-Baidu Y (1997) Wildlife and food security in Africa. Food \& Agriculture Organization of the UN (FAO).

Oakley KP (1972) Man the Tool-maker. 1 ed. British Museum (Natural History).

Ojasti J (1997) Wildlife utilization in Latin America: current situation and prospects for sustainable management. Food and Agriculture Organization of the United Nations, Rome.

Ojasti J, Dallmeier F (2000) Manejo de Fauna Silvestre Neotropical. 1 ed. Smithsonian Institution/MAB Biodiversity Program, Washington D.C.

Oldfield $S$ (2001) The trade in wildlife: regulation for conservation. 1 ed. Earthscan Publications Ltd London.

Olupona JK (1993) Some notes on animal symbolism in African religion and culture. Anthropology and Humanism 18:3-12.

Ommer RE, Perry RI (2011) Introduction. In: Ommer RE, Perry RI, Cochrane K, Cury P (eds) World Fisheries: A Social-Ecological Analysis. 1 ed. Blackwell Publishing Ltd., pp. 3-8.

Patz JA, Graczyk TK, Geller N, Vittor AY (2000) Effects of environmental change on emerging parasitic diseases. international Journal for Parasitology 30:1395-1405.

Pauwels OSG, Rodel MO, Toham AK (2003) Leptopelis notatus (Anura: Hyperoliidae) in the Massif du Chaillu, Gabon: from ethnic wars to soccer. Hamadryad 27:271-273.

Pearson RA (2005) Contributions to Society: Draught and Transport. Encyclopedia of Animal Science. 1 ed. Marcel Dekker Inc., USA, pp. 248-250.

Pedersen MC (2004) Gem and Ornamental Materials of Organic Origin. 1 ed. Elsevier Butterworth-Heinemann.

Pentenero L (2001) Los animales ayudan a afrontar problemas. La Nación, Bogotá.

Peres CA (2000) Effects of subsistence hunting on vertebrate community structure in Amazonian forests. Conservation Biology 14:240-253.

Pérez JM (2009) Parasites, Pests, and Pets in a Global World: New Perspectives and Challenges. Journal of Exotic Pet Medicine 18:248-253.

Pezzuti JCB, Rebêlo GH, Silva DF, Lima JP, Ribeiro MC (2004) A Caça ea Pesca no Parque Nacional do Jaú. Janelas para a Biodiversidade no Parque Nacional do Jaú Uma estratégia para o estudo da biodiversidade na Amazônia. 
1 ed. Borges, SH, Iwanaga, S. Durigan, CC \& Pinheiro, MR (eds.) Fundação Vitória Amazônica, Manaus, pp. 213-230.

Pezzuti JCB, Silva DF, Rebelo GH, Lima JP (2008) A captura de quelônios no

Parque Nacional do Jaú, Amazonas. In: Silva FPC, Gomes-Silva DA, Melo JS, Nascimento VM (eds) Coletânea de Textos: manejo e monitoramento de fauna silvestre em florestas tropicais, 1 ed. Belém, pp. 150-156.

Philo C, Wilbert C (2000) Animal spaces, beastly places: New geographies of human-animal relations. 1 ed. Psychology Press.

Pohl M (1976) Ethnozoology of the Maya: An analysis of fauna from five sites in Petén, Guatemala. 1 ed. Harvard University, Boston.

Pohl M (1981) Ritual continuity and transformation in Mesoamerica: Reconstructing the ancient Maya cuch ritual. American Antiquity 46:513529.

Pomeroy RS, Carlos MB (1997) Community-based coastal resource management in the Philippines: a review and evaluation of programs and projects, 1984-1994. Marine Policy 21:445-464.

Posey DA (1984) Etnoecology as applied anthropology in Amazonian development. Hum. Organ. 43:95-107.

Prins HHT, Grootenhuis JG, Dolan TT (2000) Wildlife conservation by sustainable use. 1 ed. Kluwer Academic Pub,

Pritchard JC, Lindberg AC, Main DCJ, Whay HR (2005) Assessment of the welfare of working horses, mules and donkeys, using health and behaviour parameters. Preventive Veterinary Medicine 69:265-283.

Prokop P, Fancovicova J, Kubiatko M (2009) Vampires are still alive: Slovakian students' attitudes toward bats. Anthrozoos: A Multidisciplinary Journal of The Interactions of People \& Animals 22:19-30.

Putra Y, Masy'ud B, Ulfah M (2008) Diversity of Medicinal Animals in Betung Kerihun National Park, West Kalimantan, Indonesia. Media Konservasi 13:815.

Quave CL, Lohani U, Verde A, Fajardo J, Rivera D, Obón C, Valdes A, Pieroni A (2010) A comparative assessment of zootherapeutic remedies from selected areas in Albania, Italy, Spain and Nepal. Journal of Ethnobiology 30:92-125.

Rabinowitz PM, Gordon Z, Holmes R, Taylor B, Wilcox M, Chudnov D, Nadkarni P, Dein FJ (2005) Animals as sentinels of human environmental health hazards: an evidence-based analysis. EcoHealth 2:26-37.

Ramaswamy NS (1998) Technology and Management of Working Animal Systems for Increasing the Productivity and Welfare with Special Focus on Donkeys. Proceedings of the $3^{\text {rd }}$ International Colloquium on Working Equines Mexico.

Ramsay NF, Kaye P, Ng A, O'Riordan RM, Chou LM (2007) The red-eared slider (Trachemys scripta elegans) in Asia: a review. In: Gherardi F (ed) Biological Invaders in Inland Waters: Profiles, Distribution, and Threats. 1 ed. Springer, Dordrecht, The Netherlands.

Rebêlo GH, Pezzuti JCB, Lugli L, Moreira G (2005) Pesca Artesanal de Quelônios no Pesca Artesanal de Quelônios no Pesca Artesanal de Quelônios no Parque Nacional do Jaú (AM) arque Nacional do Jaú (AM). Boletim do Museu Paraense Emílio Göeldi 1 (1): 111-127.

Redford KH, Robinson JG (1987) The Game of Choice: Patterns of Indian and Colonist Hunting in the Neotropics. American Anthropologist 89:650-667. 
Reid JT (1957) An Aspect of Symbolic Nationalism in Spanish America:(Aspirations and Emblems). Hispania 40:73-75.

Reif JS (2011) Animal Sentinels for Environmental and Public Health. Public Health Reports 126:50-57.

Reitz E, Wing ES (2001) Zooarchaeology. Cambridge Manuals in Archaeology. 1 ed. Cambridge University Press, Cambridge, UK.

Reitz EJ, Wing ES (2008) Zooarchaeology. 2 ed. Cambridge Univ Pr.

Resl B (2007) A cultural history of animals in the medieval age. 1 ed. Berg, Oxford.

Ribeiro D (1998) O processo civilizatório: etapas da evolução sociocultural. 1ed. Editora Companhia das Letras.

Ribeiro R (2006) A triste e malsucedida epopéia transatlântica da onça que "morreo de raiveza, ferrando os dentes em hum pao" O tráfico de animais no Brasil Colônia. Proceedings of the III Encontro da Associação Nacional de Pós Graduação e Pesquisa em Ambiente e Sociedade (Anppas).

Robin PA (1977) Animal lore in English literature. 1 ed. Folcroft Press, London, UK.

Robinson JG, Redford KH (1991) Neotropical wildlife use and conservation. 1 ed. University of Chicago Press, Chicago.

Robinson MM, Zhang X (2011) The World Medicines Situation 2011 - Traditional Medicines: Global Situation, Issues and Challenges. Report of the World Health Organization, Geneva.

Rocha-Mendes F, Mikich SB, Bianconi GV, Pedro WA (2005) Mamíferos do município de Fênix, Paraná: etnozoologia e conservação. Revista Brasileira de Zoologia 22:991-1002.

Rosa IL, Alves RRN, Bonifacio K, Mourão JS, Osorio F, Oliveira T, Nottingham M (2005) Fishers' knowledge and seahorse conservation in Brazil. Journal of Ethnobiology and Ethnomedicine 1:1-12.

Rosa IL, Oliveira TPR, Osório FM, Moraes LE, Castro ALC, Barros GML, Alves RRN (2011) Fisheries and trade of seahorses in Brazil: historical perspective, current trends, and future directions. Biodiversity and Conservation 20:19511971.

Rouquet P, Froment JM, Bermejo M, Kilbourn A, Karesh W, Reed P, Kumulungui B (2005) Wild animal mortality monitoring and human Ebola outbreaks, Gabon and Republic of Congo, 2001-2003. Emerging Infectious Diseases 11:283-290.

Rowland B (1973) Animals with Human Faces. 1 ed. University of Tennessee Press, Knoxville, TN.

Salamanca AM, Pajaro MG (1996) The utilization of seashells in the Philippines. Traffic Bulletin 16:61-72.

Saunders CD (2003) The emerging field of conservation psychology. Human Ecology Review 10:137-149.

Sax B (2002) The Mythological Zoo: An Encyclopedia of Animals in World Myth, Legend and Literature. 1 ed. ABC-CLIO, Inc., Santa Barbara,.

Scanes CG (2003) Biology of growth of domestic animals. 1 ed. Wiley-Blackwell, Scarpa A (1981) Pre-scientific medicines: their extent and value. Soc Sci Med 15A:317-326.

Schenck M, Nsame Effa E, Starkey M, Wilkie D, Abernethy K, Telfer P, Godoy R, Treves A (2006) Why People Eat Bushmeat: Results From Two-Choice, Taste Tests in Gabon, Central Africa. Human Ecology 34:433-445. 
Schnurrenberger PR, Hubbert WT (1981) An outline of the zoonoses. . lowa State University Press, Ames, IA.

Schoppe S (2008) Science in CITES: The Biology and Ecology of the Southeast Asian Box Turtle and its Uses and Trade in Malaysia. TRAFFIC Southeast Asia, Petaling Jaya,Selangor, Malaysia.

Scotch M, Odofin L, Rabinowitz P (2009) Linkages between animal and human health sentinel data. BMC veterinary research 5:15.

Senior M (2009) A cultural history of animals in the Age of Enlightenment. $1 \mathrm{ed.}$ Berg Publishers.

Serpell J (1990) Pet-keeping and animal domestication: a reappraisal. In: CluttonBrock J (ed) The Walking Larder: Patterns of Domestication, Pastorialism and Predation. 1 ed. Taylor \& Francis Inc., London, pp. 10-21.

Serpell JA (2006) Animal-assisted interventions in historical perspective. In: Fine $\mathrm{AH}$ (ed) Handbook on animal-assisted therapy: Theoretical foundations and guidelines for practice. 1 ed. Academic Press, San Diego, CA, pp. 3-20.

Severinghaus LL, Chi L (1999) Prayer animal release in Taiwan. Biological Conservation 89:301-304.

Sexton C (2011) The Bengal Tiger. 1 ed. Pilot Books.

Seymour C (1984) Arthropod vectors of human disease in the United States. Clinical Microbiology Newsletter 6:85-89.

Sheil D, Lawrence A (2004) Tropical biologists, local people and conservation: new opportunities for collaboration. Trends in Ecology \& Evolution 19:634638.

Sheil D, Liswanti N, van Heist M, Basuki I, Syaefuddin IS (2003) Local priorities and biodiversity in tropical forest landscapes: asking people what matters. TTO Tropical Forest Update 13:1 http://www.itto.or.jp/live/PageDiplayHandler?pageld=245.html]

Shepard P (1996) The Others: How Animals Made Us Human. 1ed. Island Press, Washington (DC).

Shepherd CR, Sukumaran J, Wich SA (2004) Open Season: An analysis of the pet trade in Medan, Sumatra 1997-2001. TRAFFIC Southeast Asia, Kuala Lumpur, Malaysia.

Sherratt A (1981) 'Plough and Pastoralism: Aspects of the Secondary Products Revolution'. In: Hodder I, Isaac G, Hammond N (eds) Patterns of the Past: Studies in Honour of David Clarke. 1 ed. Cambridge University Press, Cambridge, pp. 261-230.

Sherratt A (1983) The secondary exploitation of animals in the Old World. World Archaeology 15:90-104.

Shiu H, Stokes L (2008) Buddhist animal release practices: historic, environmental, public health and economic concerns. Contemporary Buddhism 9:181-196.

Sifuna N (2012) The Future of Traditional Customary Uses of Wildlife in Modern Africa: A Case Study of Kenya and Botswana. Journal of Biophysical Chemistry 2:31-38.

Sillitoe P (1988) From head-dresses to head-messages: the art of selfdecoration in the highlands of Papua New Guinea. Man 23:298-318.

Sillitoe P (1998) The development of indigenous knowledge. Current Anthropology 39:223-252. 
Silva MNF, Shepard Jr GH, Yu DW (2005) Conservation implications of primate hunting practices among the Matsigenka of Manu National Park. Neotropical Primates 13:31-36.

Silveira N (1998) Gatos, a emoção de lidar. 1 ed. Editora Leo Christiano, São Paulo, Brasil.

Sleeboom M (2002) The power of national symbols: the credibility of a dragon's efficacy. Nations and Nationalism 8:299-313.

Sleeman J (2006) Wildlife zoonoses for the veterinary practitioner. Journal of Exotic Pet Medicine 15:25-32.

Sodhi NS, Ehrlich PR (2010) Conservation biology for all. 1 ed. Oxford University Press Oxford, UK.

Spears NE, Mowen JC, Chakraborty G (1996) Symbolic role of animals in print advertising: Content analysis and conceptual development. Journal of Business Research 37:87-95.

Sponheimer M, Dufour DL (2009) Increased dietary breadth in early hominin evolution: revisiting arguments and evidence with a focus on biogeochemical contributions. In: Hublin JJ, Richards MP (eds) The Evolution of Hominin Diets: Integrating Approaches to the Study of Paleolithic Subsistence. Springer, Heidelberg, pp. 229-240.

Springer JT, Holley D (2012) An Introduction to Zoology: Investigating the Animal World. 1 ed. Jones \& Bartlett Learnign,

Starkey P, Mwenya E, Stares J (1994) A Worldwide View of Animal Traction Highlighting some Key Issues in Eastern and Southern Africa - Improving Animal Traction Technology. Proceedings of the first workshop of the Animal Traction Network for Eastern and Southern Africa (ATNESA), Lusaka, Zambia. Technical Centre for Agricultural and Rural Cooperation, Netherlands $490 \mathrm{p}$.

Starkey P (1995) Portraying Animal Traction in South Africa: Empowering Rural Communities. South African Network of Animal Traction, Development Bank of South Africa.

Stephen C, Ribble C (2001) Death, disease and deformity; using outbreaks in animals as sentinels for emerging environmental health risks. Global Change \& Human Health 2:108-117.

Stephenson J (1832) Medical zoology, and mineralogy; or Illustrations and descriptions of the animals and minerals employed in medicine, and of the preparations derived from them: including also an account of animal and mineral poisons. 1 ed. John Wilson.

Still J (2003) Use of animal products in traditional Chinese medicine: environmental impact and health hazards. Complementary Therapies in Medicine 11:118-122.

Straube FC (2010) As aves nos símbolos do futebol brasileiro: Escudos. Atualidades Ornitológicas 158: 33-48.

Strehlow H (2000) Zoological gardens of Western Europe. In: Kisling VN (ed) Zoo and aquarium history: ancient animal collections to zoological gardens. 1 ed. CRC Press, pp. 75-116.

Sukarmi S, Sabdono A (2011) Ethical perspectives of sustainable use of reef's invertebrates as a source of marine natural products. Journal of Coastal Development 11:97-103.

Sulman FG (1982) Short and Long-Term Changes in Climate. 1 ed. CRC Press, Boca Raton, FL. 
Takeda J (1998) Plants and animals used on birth and death of the Ngandu (Bongando) in Central Zaire. African study monographs. Supplementary issue. 25:135-148.

Taylor LH, Latham SM, Mark EJ (2001) Risk factors for human disease emergence. Philosophical Transactions of the Royal Society of London. Series B: Biological Sciences 356:983-989.

Thomas WLJ (1956) Man's Role in Changing the Face of the Earth. 1 ed. University of Chicago Press, Chicago.

Thomsen JB, Brautigam A (1991) Sustainable use of neotropical parrots. In: Robinson JG, Redford KH (eds) Neotropical wildlife use and conservation. 1 ed. University of Chicago Press, Chicago, pp. 359-380.

Thomsen JB, Mulliken TA (1992) Trade in Neotropical Psittacines and Its. In: Beissinger SR, Snyder NFR (eds) New World parrots in crisis: solutions from conservation biology. 1 ed. Smithsonian Institution Press, Washington, pp. 359379.

Tidemann S, Gosler A (2010) Ethno-ornithology: Birds, Indigenous People, Culture and Society. 1 ed. Earthscan/James \& James,

Tomalin E (2004) Bio-divinity and biodiversity: Perspectives on religion and environmental conservation in India. Numen 51:265-295.

Tröeng S, Drews C (2004) Money talks: economic aspects of marine turtle use and conservation. WWF International, Switzerland.

Trowell S (2003) Drugs from Bugs: The Promise Of Pharmaceutical Entomology. Futurist 37:17-19.

Tsuchiya K (1992) Historical perspectives in occupational medicine. The discovery of the causal agent of minamata disease. American journal of industrial medicine 21:275-280.

Turner K, Freedman B (2004) Music and environmental studies. The Journal of Environmental Education 36:45-52.

Unnikrishnan E (2004) Materia Medica of the Local Health Traditions of Payyannur. Discussion Paper $N^{\circ}$. 80, Kerala Research Programme on Local Level Development. Centre for Development Studies.

Unnikrishnan PM (1998) Animals in Ayurveda. Amruth Suppl 1:1-15.

USCRTF (2000) International trade in coral and coral reef species: the role of the United States. USCRTF-United States Coral Reef Task Force, Washington.

Vincent ACJ (1996) The international trade in seahorses. Traffic International, Cambridge.

Vincent ACJ, Foster SJ, Koldewey HJ (2011) Conservation and management of seahorses and other Syngnathidae. Journal of Fish Biology 78:1681-1724.

Vitousek PM, Mooney HA, Lubchenco J, Melillo JM (1997) Human domination of Earth's ecosystems. Science 277:494-499.

Voultsiadou $E$ (2010) Therapeutic properties and uses of marine invertebrates in the ancient Greek world and early Byzantium. Journal of Ethnopharmacology 130 237-247

Walsh JF, Molyneux DH, Birley MH (1993) Deforestation: effects on vector-borne disease. Parasitology 106:S55-75.

Warkentin IG, Bickford D, Sodhi NS, Bradshaw CJA (2009) Eating frogs to extinction. Conservation Biology 23:1056-1059. 
Warwick C, Lindley S, Steedman C (2011) How to handle pets: a guide to the complexities of enforcing animal welfare and disease control. Environmental Health News 8:18-19. 8:18-19.

Waters MR, Stafford Jr TW, McDonald HG, Gustafson C, Rasmussen M, Cappellini E, Olsen JV, Szklarczyk D, Jensen LJ, Gilbert MTP (2011) Pre-Clovis Mastodon Hunting 13,800 Years Ago at the Manis Site, Washington. Science 334:351-353.

Weiss RA (2001) The Leeuwenhoek Lecture 2001. Animal origins of human infectious disease. Philosophical Transactions of the Royal Society of London. Series B: Biological Sciences 356:957-977.

Wells SE (1981) International trade in ornamental corals and shells. Proceedings of fourth International Coral Reef Symposium, vol. 1, pp. 323-330.

Whiting MJ, Williams VL, Hibbitts TJ (2011) Animals traded for traditional medicine at the Faraday market in South Africa: species diversity and conservation implications. Journal of Zoology 284:84-96.

WHO (2005) Ecosystems and human well-being : health synthesis : a report of the Millennium Ecosystem Assessment. 1 ed. WHO, Geneva, Switzerland.

Williams ES, Yuill T, Artois M, Fischer J, Haigh SA (2002) Emerging infectious diseases in wildlife. Revue Scientifique et Technique-Office International des Epizooties 21:139-158.

Wolfe ND, Dunavan CP, Diamond J (2007) Origins of major human infectious diseases. Nature 477:279-283.

Wood E, Wells S (1995) The shell trade: a case for sustainable utilization. In: Kay EA (ed) The conservation biology of molluscs. IUCN Species Survival Commission, Cambridge.

Wood EM, Wells S (1988) The Marine Curio Trade: Conservation Issues: a Report for the Marine Conservation Society. Marine Conservation Society. $120 p$.

Woolhouse ME, Gowtage-Sequeria S (2005) Host range and emerging and reemerging pathogens. Emerging Infections Diseases 11:1842-1847.

World Resources Institute (2000) People and ecosystems the fraying web of life. World Resources Institute, Washington D.C.

Yamakoshi G (2005) What is happening on the border between humans and chimpanzees? Wildlife conservation in West African rural landscapes. In: Hiramatsu K (ed) Coexistence with Nature in a "Globalising" World: FieldScience Perspectives. Procedings of the 7th Kyoto University International Symposium, Kyoto, Japan, pp.91-97.

Yearbook IZ (2012) Index to List of Zoos and Aquariums of the World. International Zoo Yearbook 46:439-455.

Yinfeng G, Xueying Z, Yan C, Di W, Sung W (1997) Sustainability of wildlife use in Traditional Chinese Medicine.

Yoder AE (1947) Animal analogy in Shakespeare's character portrayal. 1 ed. King's Crown Press.

Zangpo S (2005) Releasing Life: An Ancient Buddhist Practice in the Modern World. 1 ed. The Corporate Body of the Buddha Educational Foundation, Taiwan.

Zuckerman L (1979) Great zoos of the world: their origins and significance. 1 ed. Weidenfeld and Nicolson., London. 